\title{
Delivery after caesarean
}

Citation for published version (APA):

Vankan, E. (2021). Delivery after caesarean: chances and choices. [Doctoral Thesis, Maastricht University]. Ridderprint. https://doi.org/10.26481/dis.20211112ev

Document status and date:

Published: 01/01/2021

DOI:

10.26481/dis.20211112ev

Document Version:

Publisher's PDF, also known as Version of record

\section{Please check the document version of this publication:}

- A submitted manuscript is the version of the article upon submission and before peer-review. There can be important differences between the submitted version and the official published version of record.

People interested in the research are advised to contact the author for the final version of the publication, or visit the DOI to the publisher's website.

- The final author version and the galley proof are versions of the publication after peer review.

- The final published version features the final layout of the paper including the volume, issue and page numbers.

Link to publication

\footnotetext{
General rights rights.

- You may freely distribute the URL identifying the publication in the public portal. please follow below link for the End User Agreement:

www.umlib.nl/taverne-license

Take down policy

If you believe that this document breaches copyright please contact us at:

repository@maastrichtuniversity.nl

providing details and we will investigate your claim.
}

Copyright and moral rights for the publications made accessible in the public portal are retained by the authors and/or other copyright owners and it is a condition of accessing publications that users recognise and abide by the legal requirements associated with these

- Users may download and print one copy of any publication from the public portal for the purpose of private study or research.

- You may not further distribute the material or use it for any profit-making activity or commercial gain

If the publication is distributed under the terms of Article $25 \mathrm{fa}$ of the Dutch Copyright Act, indicated by the "Taverne" license above, 


\section{DELIVERY AFTER CAESAREAN CHANCES AND CHOICES}


(c) E.Vankan, Maastricht, 2021

ISBN: 978-94-6416-775-7

Cover design and layout: (c) evelienjagtman.com

Production: Ridderprint, Alblasserdam

The research presented in this thesis was performed within GROW, School for Oncology and Developmental Biology at Maastricht University.

This research was funded by the Netherlands Organisation for Health Research and Development (ZonMW grant No 17100.3006). 


\title{
DELIVERY AFTER CAESAREAN CHANCES AND CHOICES
}

\author{
PROEFSCHRIFT
}

\author{
ter verkrijging van de graad van doctor \\ aan de Universiteit Maastricht, \\ op gezag van de Rector Magnificus, \\ Prof. dr. Rianne M. Letschert
}

volgens het besluit van het College van Decanen,

in het openbaar te verdedigen

op vrijdag 12 november 2021 om 12:00

door

Emy Vankan 


\section{Promotor}

Prof. dr. J.G. Nijhuis

\section{Copromotoren}

Dr. H.C.J. Scheepers

Dr. R.P.M.G. Hermens, IQ healthcare Radboud Universitair Medisch Centrum

\section{Beoordelingscommissie}

Prof. dr. P.W. Teunissen, voorzitter

Prof. dr. M.L. Smidt

Dr. L. Wynants, KU Leuven, België

Dr. A.C.M.J. Merkx, Academie Verloskunde Maastricht-Zuyd

Dr. J. Braspenning, IQ healthcare Radboud Universitair Medisch Centrum 


\section{Table of contents}

Chapter 1 General introduction 7

Chapter 2 Practice variation of vaginal birth after cesarean and the influence of risk factors at patient level: a retrospective cohort study

Acta Obstet Gynecol Scand, 2017 Feb;96(2):158-165

Chapter 3 Involving women in personalised decision-making on mode of delivery after caesarean section: the development and pilot testing of a patient decision aid BJOG: An international journal of Obstetrics and Gynaecology 2014;121:202-209

Chapter 4 The effect of the use of a decision aid with individual risk estimation on the mode of delivery after a caesarean section: a prospective cohort study

Plos one, 2019 Sep 26;14

Chapter 5 External validation of a prediction model on vaginal birth after caesarean in The Netherlands: a prospective cohort study

J Perinat Med. 2020 Nov 6;49(3): 357-363

Chapter 6 Summary and General Discussion

109

Chapter 7 Impact

Chapter 8 Nederlandstalige samenvatting

$\begin{array}{lll}\text { Appendices Dankwoord } & 137\end{array}$

Curriculum Vitae 143

List of publications $\quad 145$ 


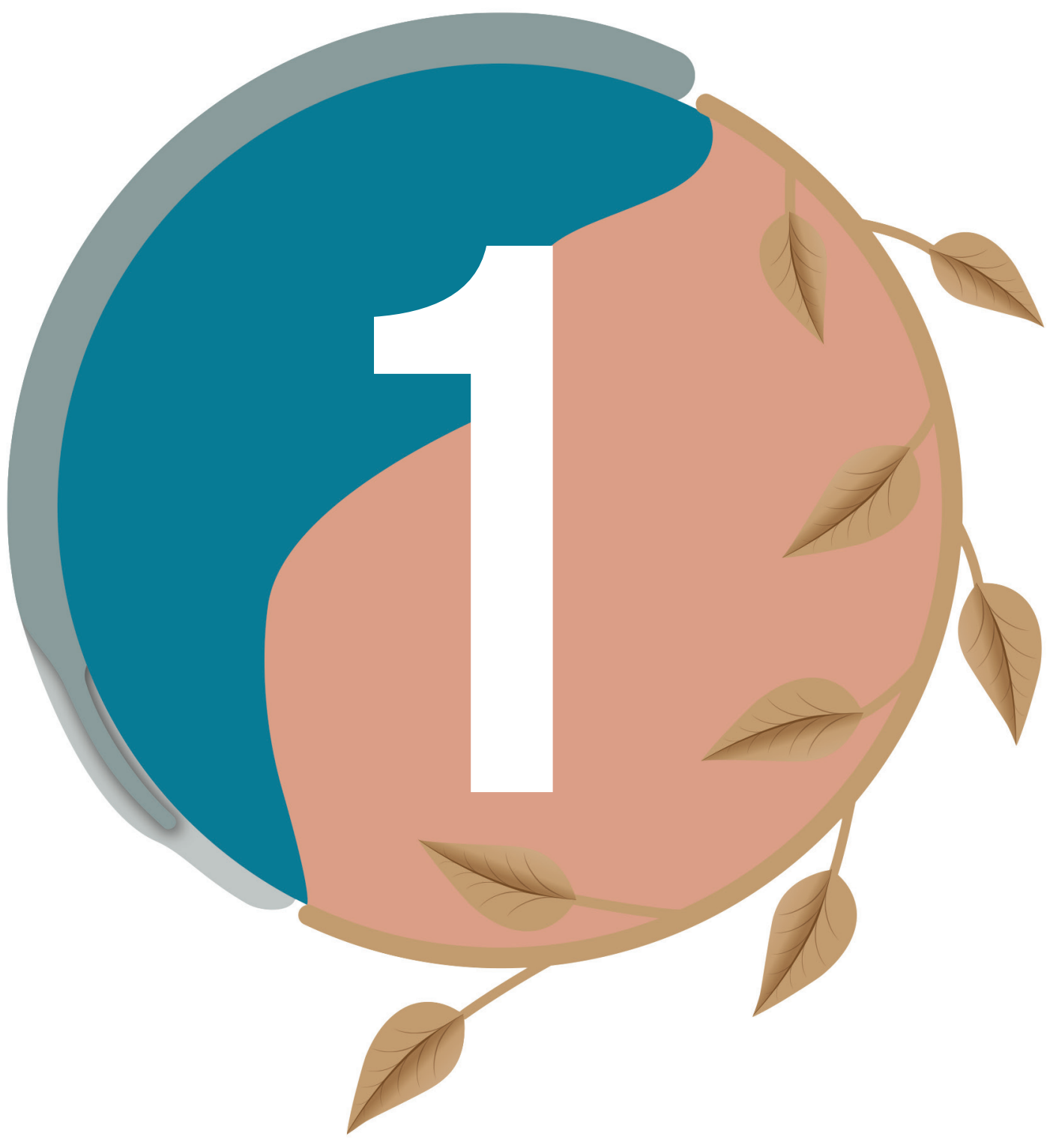


Chapter 1

General introduction 


$$
\text { . }
$$




\section{General introduction}

The caesarean section (CS) is aimed to prevent maternal and neonatal morbidity and mortality when medically required, without improved perinatal outcome. However, when a CS is not strictly indicated, risks for both mother and child increase. In the last decades a considerable rise in CS rate was seen worldwide. In some countries like Turkey and Mexico CS rates have raised up to 48-53\% [1]. This increase in surgical delivery leads to concerns about the elevated risk on maternal and neonatal morbidity and mortality [2]. In the Netherlands the CS rate is relatively low, $15.7 \%$ in 2019 [3].

Improvement of care is necessary to prevent a further rise in CS rate. Contemporary guidelines give evidence-based recommendations on when to offer or perform a CS. Guideline-adherence can be significant in improving CS rates. Various factors are of influence, factors at patient, caregiver, hospital and society level. Melman et al. developed and measured CS quality indicators and revealed low guideline adherence in women delivering after a previous caesarean section and counselling these women for mode of delivery [4]. In this thesis we want to focus on this group of patients and assess the variation between hospitals concerning mode of delivery after a previous CS and to what extent this is influenced by medical factors at patient level. We aimed to develop a tool to improve counseling according to the guidelines and support decision making. Subsequently, the effects of this tool will be evaluated in daily practice.

\section{Definitions}

A caesarean section is a surgical delivery, where the child is delivered through an abdominal and uterine incision. Several definitions are used to describe the delivery after a previous CS. Trial of labour (TOL) or trial of labour after caesarean (TOLAC) is used when women start their delivery with the intention to give birth naturally. After a trial of labour, a woman finally delivers by a vaginal birth after caesarean (VBAC) or an unplanned or emergency CS. If a woman does not prefer to have a trial of labour, she can decide to have a planned or elective repeat caesarean section (ERCS).

\section{Mode of delivery after previous caesarean section}

Women pregnant after a previous CS can deliver by ERCS or TOL, which can end in a VBAC or unplanned CS. Both options have benefits and risks. A VBAC is associated with the smallest risk of complications (0.2\%), followed by an ERCS (0.8\%). The highest incidence of complications is seen in an unplanned CS (3.8\%) [5]. 
Women delivering by VBAC have the experience of a natural birth and admission at the hospital and recovery is shorter [6]. Mother and child are less likely to be separated and breastfeeding can be started immediately. The chance of a vaginal delivery in the future is increased. At the same time, there is a higher risk of uterine rupture $(0.2-0.7 \%$ vs $0.03 \%)$ [7,8]. This risk rises when labour is induced of augmented. A uterine rupture is associated with maternal morbidity (hemorrhage, hysterectomy and intensive care admission) and neonatal morbidity (asphyxia and neonatal intensive care admission) and mortality [9]. The chance of perinatal death is 1.3 per 1000 deliveries in TOL [10]. In VBAC the risk of instrumental delivery (39\%) is increased compared to nulliparous women [11]. Furthermore, as mentioned before, chance of an emergency CS lasts.

When women deliver by ERCS, they have the ability to plan the date and circumstances around their delivery (except when labour starts). The risk of a uterine rupture is strongly diminished (0.3 per 1000 deliveries) and risk of perinatal death is very Iow $(<0.01 \%)[7,10]$. During the procedure of a CS, a sterilization as a permanent contraception can be performed on request. An increased risk on hemorrhage, infection and thrombosis arises from the surgical procedure. The risk on maternal death is increased (0.013\% vs 0.004\%) [10]. After an ERCS hospital stay and recovery is longer compared to after a VBAC. Furthermore, in ERCS is a higher risk of thromboembolic events, surgical injury, puerperal fever and abdominal woundinfection $[5,10]$. Abdominal adhesions and placenta praevia and accreta are more often seen in future pregnancies.

\section{Implementation of guidelines}

According to contemporary international guidelines women have the right to make a choice in mode of delivery when no contra-indications exist $[12,13,14]$. However, several studies show large practice variation concerning mode of deliver after caesarean around the world $[8,15,16]$. This suggests also variation in implementation of the guidelines. Several factors are of influence on the TOL and VBAC rate: patientrelated factors (ethnicity, medical history, obstetrical history, features of the current pregnancy, preference of the patient), factors at caregiver level (liability, experience), factors at hospital level (availability of emergency care, type of hospital, centralization) and type of insurance [15]. Understanding of these factors is important for complete implementation of the guidelines. In this thesis we will evaluate practice variation in VBAC in the Netherlands and assess the impact patient-related factors on the VBAC rates (chapter 2 ). 


\section{Counselling for mode of delivery}

To be able to make an informed choice, women should be adequately informed about their choices according to the contemporary guidelines. However, guideline-adherence regarding counselling is low in this group [4]. Women pregnant after a previous CS must be informed about the benefits and risks of a TOL and ERCS. A number of key points need to be discussed: the chance of VBAC, the risk of uterine rupture and the elevated risk in case of induction of augmentation of labour, the risk of neonatal morbidity and mortality, the risks and benefits of an ERCS and implications for future pregnancies. A study from Melman et al. showed that women are often not adequately informed about these topics due to fear of the caregiver for a rise in CS rate. A barrier for adequate counseling mentioned by caregivers is the perception that balancing risks for mother and child in the current pregnancy and future pregnancies might be challenging for women [17].

\section{Decision making}

Decision making in mode of delivery after previous CS is complex, because the woman has to make a decision concerning her own health and the health of her unborn child. Several factors influence the decision; previous birth experiences, expectations, features of the current pregnancy, the risks of both options of delivery mode, information sources and discussion with the caregiver about the options [18]. Despite the complexity of the decision making, women desire to be involved in this process. Ideally the mode of delivery is discussed in a shared decision-making setting. Several studies showed a decision aid (DA) is an effective tool to support the decision-making process and improve shared decision making $[19,20,21]$. A DA enhances the knowledge of the patient about the different options, supports the communication between the patient en the caregiver and improves patient involvement. Furthermore, a DA can be used as tool for improving guideline adherence, since all the recommendations can be implemented in the DA. For these reasons, it is necessary to develop a DA for mode of delivery after previous caesarean. The effect of a DA on mode of delivery, guideline adherence and satisfaction of the patient has not been evaluated yet.

\section{Predicting chance on VBAC}

A key item of counseling mode of delivery is discussing the chance of a VBAC. This chance could be a determining factor in the final decision. Patients prefer information suitable to their individual circumstances [22]. However, the reported successful TOL rates are not applicable to an individual. Several prediction models have been developed to predict the chance on VBAC [23-27]. In this thesis a prediction model is implemented in the DA to support decision making and individualise counseling [27]. However, before a prediction model can be implemented as part of a decision aid for counselling mode of delivery, external validation is necessary and performed in this thesis. 


\section{Aim of this thesis}

The increase in CS rate and consequently in women pregnant after previous CS leads to an elevated risk of maternal and neonatal morbidity and mortality. The caesarean Section IMPLEmentation (SIMPLE) study is designed to explore the current quality of care on CS in The Netherlands. The aim of this study is to gain more insight on factors influencing daily practice on mode of delivery after previous caesarean. A patient decision aid will be designed and tested to improve care, guideline-adherence and patient involvement in women pregnant after previous CS.

Research questions of this thesis

1. To what extent can practice variation in mode of delivery after previous CS be explained by risk factors at patient level? (Chapter 2)

2. How to develop and pilot-test a patient decision aid with integrated prediction model for mode of delivery after previous CS? (Chapter 3)

3. What is the effect of counseling with a decision aid including prediction model for mode of delivery after CS? (Chapter 4)

- On the VBAC rate

- On patient involvement in decision-making

- On guideline adherence

- On maternal and neonatal complications

4. Is the used prediction model proven externally valid for implementation in daily practice? (Chapter 5) 


\section{References}

1. OECD (2019), Health at a Glance 2019: OECD Indicators, OECD Publishing, Paris, https://doi. org/10.1787/4dd50c09-en.

2. Villar J, Carroli G, Zavaleta N, Donner A, Wojdyla D, Faundes A, Velazco A, Bataglia V, Langer A, Narváez A, Valladares E, Shah A, Campodónico L, Romero M, Reynoso S, de Pádua KS, Giordano D, Kublickas M, Acosta A; World Health Organization 2005 Global Survey on Maternal and Perinatal Health Research Group.Villar J, et al, Maternal and neonatal individual risks and benefits associated with caesarean delivery: multicentre prospective study, BMJ. 2007 Nov 17;335(7628):1025.

3. Perined, Perinatale zorg in Nederland anno 2019: landelijke perinatale cijfers en duiding, Utrecht 2020

4. Melman S, Schoorel EC, de Boer K, Burggraaf H, Derks JB, van Dijk D, van Dillen J, Dirksen CD, Duvekot JJ, Franx A, Hasaart TH, Huisjes AJ, Kolkman D, van Kuijk S, Kwee A, Mol BW, van Pampus MG, de Roon-Immerzeel A, van Roosmalen JJ, Roumen FJ, Smid-Koopman E, Smits L, Spaans WA, Visser H, van Wijngaarden WJ, Willekes C, Wouters MG, Nijhuis JG, Hermens RP, Scheepers HC, Development and Measurement of Guidelines-Based Quality Indicators of Caesarean Section Care in the Netherlands: A RAND-Modified Delphi Procedure and Retrospective Medical Chart Review., PLoS One. 2016 Jan 19;11(1):e0145771.

5. McMahon MJ, Luther ER, Bowes WA, Olshan AF, Comparison of a trial of labor with an elective second cesarean section, N Eng J Med. 1996 Sep 5;335(10):689-95

6. Shorten A, Shorten B.Shorten A, et al. The importance of mode of birth after previous cesarean: success, satisfaction, and postnatal health., J Midwifery Womens Health. 2012 Mar-Apr;57(2):126-32.

7. Kathryn E Fitzpatrick, Jennifer J Kurinczuk, Zarko Alfirevic, Patsy Spark, Peter Brocklehurst, Marian Knight_Uterine rupture by intended mode of delivery in the UK: a national case-control study, PLoS Med. 2012;9(3):e1001184. doi: 10.1371/journal.pmed.1001184. Epub 2012 Mar 13.

8. Kwee A, Bots ML, Visser GHA, Bruinse HW. Obstetric management and outcome of pregnancy in women with a history of caesarean section in the Netherlands. Eur J Obstet Gynecol Reprod Biol. 2007; 132: $171-76$

9. J Zwart, J M Richters, F Ory, J I P de Vries, K W M Bloemenkamp, J van Roosmalen, Uterine rupture in The Netherlands: a nationwide population-based cohort study, BJOG, 2009 Jul;116(8):1069-78; discussion 1078-80.

10. National Institutes of Health Consensus Development Conference Statement vaginal birth after cesarean: new insights March 8-10, 2010. Semin Perinatol 2010; 34(5): 351-65.

11. Rotem Inbar, Shali Mazaaki, Anat Kalter, Itai Gat, Eyal Sivan, Eyal Schiff, Israel Hendler, Trial of labour after caesarean (TOLAC) is associated with increased risk for instrumental delivery, J Obstet Gynaecol, 2017 Jan;37(1):44-47.

12. ACOG Practice bulletin no. 115: Vaginal birth after previous cesarean delivery. Obstet Gynecol, 2010. 116(2 Pt 1): 450-63.

13. NICE, Caesarean Section, clinical guideline. 2011, London: National Collaborating Centre for Women's and Children's Health.

14. RCOG, Birth after previous caesarean birth. Green-Top Guideline, 2015.

15. Guise JM, Eden K, Emeis C, Denman MA, Marshall N, Fu RR et al. Vaginal birth after cesarean: new insights. Evid Rep Technol Assess (Full Rep), 2010(191): 1-397.

16. Jocelyn Toohill, Jenny, Gamble, Debra K Creedy, A critical review of vaginal birth rates after a primary Caesarean in Queensland hospitals, Aust Health Rev, 2013 Nov;37(5):642-8. 
17. Melman S, Schreurs RHP, Dirksen CD, Kwee A, Nijhuis JG, Smeets NAC, Scheepers HCJ, Hermens RPMG, Identification of barriers and facilitators for optimal cesarean section care: perspective of professionals.,BMC Pregnancy Childbirth. 2017 Jul 14;17(1):230.

18. Chen SW, Hutchinson AM, Nagle C, Bucknall TK, Women's decision-making processes and the influences on their mode of birth following a previous caesarean section in Taiwan: a qualitative study..BMC Pregnancy Childbirth. 2018 Jan 17;18(1):31.

19. Stacey D, Legare F, Col NF, Bennet CL, Barry MJ, Eden KB et al., Decision aids for people facing health treatment or screening decisions. Cochrane Database Syst Rev, 2014(1): CD001431.

20. Shorten AB, Shorten B, Keogh J, West S, Morris J, Making choices for childbirth: a randomized controlled trial of a decision-aid for informed birth after cesarean. Birth, 2005. 32(4): 252-61.

21. Montgomery AA, Emmett CL, Fahey T, Jones C, Ricketts I, Patel RR et al., Two decision aids for mode of delivery among women with previous caesarean section: randomized controlled trial. BMJ, 2007. 334(7607): 1305

22. Moffat MA, Bell JS, Porter MA, Lawton S, Hundley V, Danielian P, Bhattacharya S.Moffat MA, Decision making about mode of delivery among pregnant women who have previously had a caesarean section: A qualitative study. , et al. BJOG. 2007 Jan;114(1):86-93

23. Annessi E, Del Giovane C, Magnani L, Carossino E, Baldoni G, Battagliarin G, et al. A modified prediction model for VBAC, in a European population. J Matern Fetal Neonatal Med, 2016;29:435-9.

24. Fagerberg MC, Marsal K, Kallen K, Predicting the chance of vaginal delivery after one caesarean section: validation and elaboration of a published prediction model. Eur J Obstet Gynecol Reprod Biol, 2015;188:88-94.

25. Grobman, WA, Lai Y, Landon MB, Spong CY, Leveno KJ, Rouse DJ, et al. Development of a nomogram for prediction of vaginal birth after caesarean delivery. Obstet Gynecol, 2007:109:806-12.

26. Grobman WA, Lai Y, Landon MB, Spong CY, Leveno KJ, Rouse DJ, et al. Does information available at admission for delivery improve prediction of vaginal birth after caesarean? Am J Perinatol, 2009;26:693-701.

27. Schoorel ENC, van Kuijk SMJ, Melman S, Nijhuis JG, Smits LJM, Aardenburg R, et al. Vaginal birth after a caesarean section: the development of a Western European population-based prediction model for deliveries at term. BJOG, 2014;121:194-201; discussion 201. 


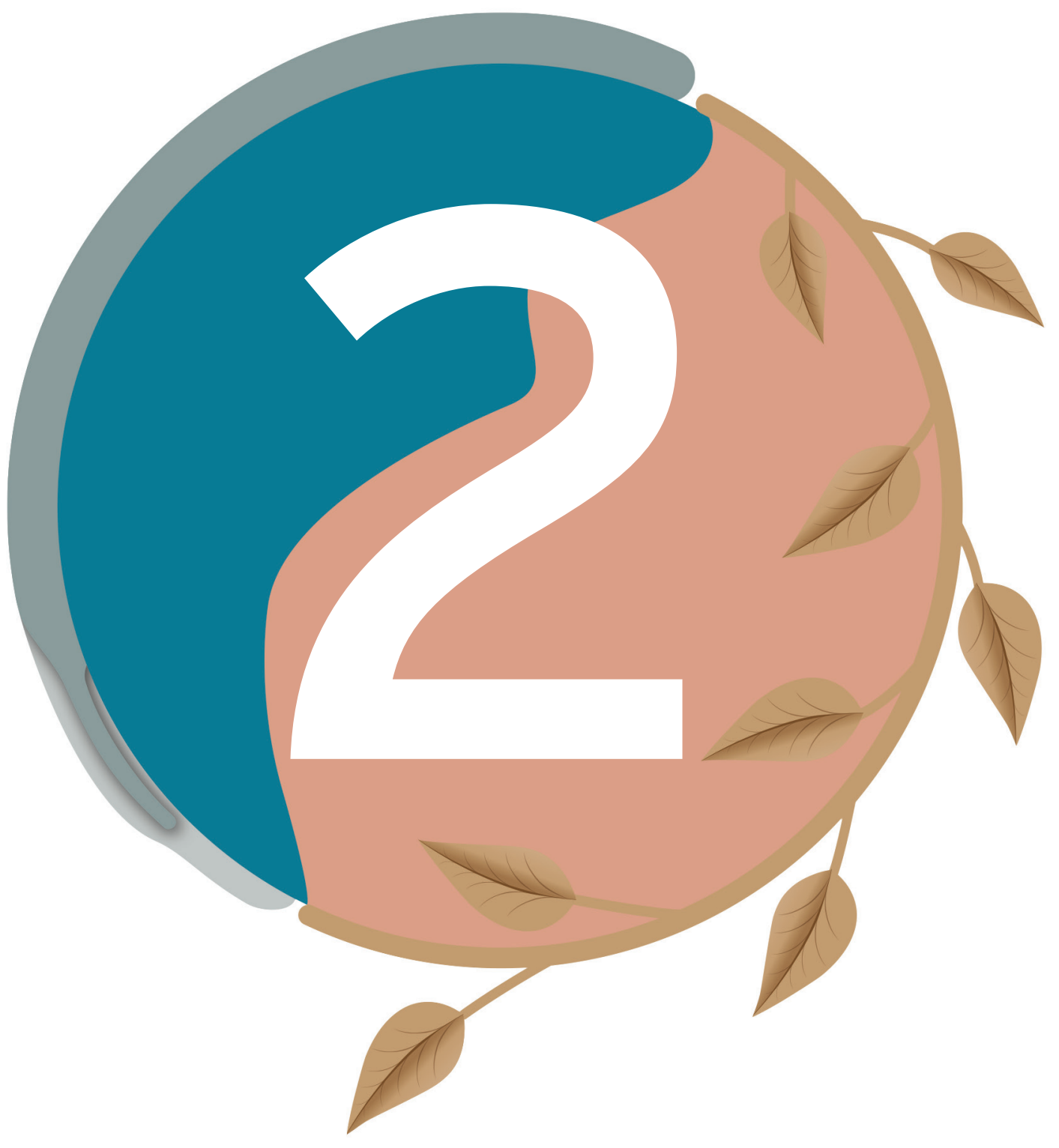




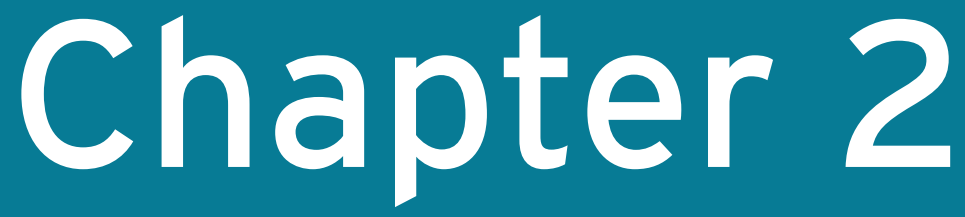

\section{Practice variation of vaginal birth after cesarean and the influence of risk factors at patient level: a retrospective cohort study}

Vankan E, Schoorel EN, van Kuijk SM, Mol BJ, Nijhuis JG, Aardenburg R, Alink M, de Boer K, Delemarre FM, Dirksen CD, van Dooren IM, Franssen MT, Kaplan M, Kleiverda G, Kuppens SM, Kwee A, Langenveld J, Lim FT, Melman S, Sikkema MJ, Smits LJ, Visser H, Woiski M, Scheepers HC, Hermens RP Acta Obstet Gynecol Scand, 2017 Feb;96(2):158-165 


\section{Abstract}

\section{Introduction}

Large practice variation exists in mode of delivery after cesarean section (CS), suggesting variation in implementation of contemporary guidelines. We aim to evaluate this practice variation and to what extent this can be explained by risk factors at patient level.

\section{Material and Methods}

This retrospective cohort study was performed amongst 17 Dutch hospitals in 2010 . Women with one prior CS without a contraindication for a trial of labor (TOL) were included. We used multivariate logistic regression analysis to develop models for risk factor adjustments. One model was derived to adjust the elective repeat CS (ERCS) rates; a second model to adjust vaginal birth after cesarean (VBAC) rates. Standardized rates of ERCS and VBAC per hospital were compared. Pseudo-R-squared measures were calculated to estimate the percentage of practice variation explained by the models. Secondary outcomes were differences in practice variation between hospital types and the correlation between standardized ERCS- and VBAC rates.

\section{Results}

1068 women had a history of CS of whom $71 \%$ were eligible for inclusion. 515 women (67\%) had a TOL of whom $72 \%$ delivered vaginally. The ERCS rate at hospital level ranged from $6 \%$ to $54 \%$ (mean 29.8 , standard deviation (SD) $11.8 \%$ ). VBAC rates ranged from $50 \%$ to $90 \%$ (mean $71.8 \%$, SD $11.1 \%$ ). More than $85 \%$ of this practice variation could not be explained by risk factors at patient level.

\section{Conclusions}

A large practice variation exists in ERCS- and VBAC rates that can only partially be explained by risk factors at patient level. 


\section{Introduction}

The numbers of women who are pregnant following a cesarean section (CS) have increased in many parts of the world. Guidelines were developed that advice on how to counsel women on mode of birth after CS and how to organize care [1-5]. During this counseling, women should be given information including benefits and risks of both options and ideally, shared decision making must take place. Women can choose for elective repeat CS (ERCS) or start a vaginal delivery (trial of labor (TOL)), ending in a vaginal birth after cesarean (VBAC) or an unplanned CS. Studies show large practice variation in TOL rates $[6,7]$ both at national and international level, suggesting large variation in implementation of contemporary guidelines. Yet, these studies did not correct for factors at patient level, hence the results should be interpreted with caution as variation in patient populations might induce this practice variation. One would expect that when patients are counseled according to risk status, higher ERCS rates would be associated with higher actual VBAC in those women attempting VBAC. Besides, practice variation might not only be dependent on factors at patient level, but also on type of hospital. University hospitals could have another organization than nonuniversity teaching and non-teaching hospitals. Insight into these factors is necessary before full implementation of guidelines can be achieved.

In order to accurately analyze practice variation, we aim to evaluate practice variation in mode of delivery after CS and particularly to what extent it can be explained by factors at patient level. Secondary, we aim to evaluate if the type of hospital influences practice variation as well. Finally, we will analyze the correlation between ERCS rates and $V B A C$ rates. 


\section{Materials and methods}

In a nationwide retrospective cohort study, we compared care regarding mode of delivery for women who are pregnant after a CS, amongst 17 Dutch hospitals in terms of practice variation. All enrolled hospitals participated in the Dutch consortium of obstetrics and gynecology and were representative for Dutch geographic regions and hospital types. The present study was performed in academic teaching hospitals $(n=5)$, non-academic teaching hospitals $(n=7)$ and non-academic non-teaching hospitals $(n=5)$. Consecutive deliveries were recorded per site starting at January $1^{\text {st }}$ 2010. All enrolled sites were requested to include 30 consecutive women who had a TOL and all women who had an ERCS in the same time-interval. This resulted in an overview of all women who had delivered within the set time-interval and had 1 or $\geq 2$ prior CS's. Data collection for all hospitals was completed within the year 2010. Subsequently, a database was constructed that included all women who had one prior CS.

We included women with a history of one prior CS and a vertex singleton pregnancy who delivered at $\geq 37$ weeks gestational age (GA). Women were excluded when they had an unknown indication of prior CS or in the current pregnancy an intra-uterine fetal demise or a contraindication for a TOL. A contraindication for TOL was defined as a previous uterine rupture, a placenta previa or a relevant uterine scar.

These women received oral and/or written information on the mode of delivery from their obstetrician or midwives during one or, if preferred, more consultations in their pregnancy. The discussion and decision on mode of delivery takes place around 36 weeks during consultation with the obstetrician.

The main outcome measures of this study were the amount of variation in ERCSand VBAC rates between hospitals corrected for risk factors at patient level. Concerning these factors, we selected variables based on their predictive ability for VBAC found in literature, existing prediction models and expert opinion $[8,9]$. Secondary outcome measures were the differences in practice variation between hospital types and whether there was a correlation between standardized ERCSand $V B A C$ rates.

There is consensus about the maximum number of predictors that can be validly included in a prediction model. It is recommended that at least ten events are collected for each potential predictor that is evaluated in the multivariable regression analysis [10]. An event is defined as the least frequent outcome status, 
which is in our case an unplanned CS. In the Netherlands the estimated event rate, i.e. TOL failure rate, is 24-28\% [11,12]. Therefore, in order to develop a model with 14 potential predictors, at least 140 events were required. Hence, a sample size of at least 500 participants was required $(140 / 28 * 100)$.

We collected data on frequencies of mode of delivery after CS per hospital. To investigate the influence of risk factors at patient level, data were gathered with regard to demographic factors (maternal age and ethnicity), past obstetric factors and pre-existing and current obstetric factors. Obstetric factors included variables that are predictive for mode of birth after CS and for VBAC. These variables were chosen based on published prediction models on VBAC, original research articles that report on predictors for mode of birth after CS, VBAC and on expert opinion [8,9]. The variables considered relevant for assessing the influence of risk factors at patient level included maternal age, pre-pregnancy body-massindex (BMI), ethnicity, prior non-progressive labor, any prior VBAC, any prior vaginal delivery, estimated fetal weight (EFW) $\geq p 90$, diabetes mellitus, hypertension, preeclampsia/ HELLP syndrome. Pre-pregnancy BMI was defined as $\mathrm{kg} / \mathrm{m}^{2}$ obtained pre-pregnancy or within the first trimester. EFW was measured in the third trimester by either ultrasound or upon physical examination. Diabetes mellitus and hypertension could be either pre-existent or pregnancy induced. For prediction of VBAC we added to this set whether labor was induced and labor parameters upon presentation to the labor ward (cervical dilation, cervical effacement and fetal station). Cervical dilation was registered per centimeter (range 0-10). Cervical effacement was categorized in three measures: 0-25\%, 25-50\%, >50\%. Fetal engagement was recorded according to the 'Hodge classification system' (range $\mathrm{HO}-\mathrm{H} 4$ ) and converted to the American classification system ranging from ballotable (B) to +5 . This variable was defined as follows: $\mathrm{HO}=-5, \mathrm{H1}=-3, \mathrm{H2}=-1, \mathrm{H3}=\mathrm{O}, \mathrm{H} 4=+3$.

Data were extracted from medical records by trained research staff using customized case report forms. Data were checked for completeness and inconsistencies. Inconsistent and incomplete data were double-checked directly with the hospital concerned.

All missing data were imputed using single stochastic regression imputation since omission of incomplete cases can result in loss of precision and may bias the results $[13,14]$. For imputation, all quantitative baseline characteristics were used for estimation of the missing values. We assumed data were missing at random (MAR), which is an assumption of the imputation model that we used." For assessing the influence of risk factors at patient level, we derived two multivariate logistic regression models that predicted ERCS and VBAC, respectively. One model was used to correct ERCS rates for risk factors at patient level, while the second model was used to correct VBAC rates for risk factors at patient level. The multivariate logistic regression models were developed 
using a backwards stepwise elimination method. At first, we performed univariate analyses to assess which risk factors at patient level could be related to the outcome variables. In order to minimize the risk of exclusion of important variables, we used a liberal p-value of 0.2 to estimate which variables were univariate significantly related to the outcome variables [8]. Subsequently, the multivariate logistic regression formula was applied to the dataset to calculate both the probability of ERCS and VBAC per woman. Mean predicted outcomes per hospital represented the expected ERCS- and VBAC rates per hospital. Expected ERCS and VBAC rates per hospital were compared to the 'true', 'observed' rates. Accordingly, for each hospital, standardized rates were computed by dividing observed rates by expected rates and multiplying it by the population mean. The standardized rate represents the ERCS and VBAC rates that the hospital would have if all hospitals had a similar patient population. Pseudo-R-squared measures were obtained for estimation of the total percentage of practice variation that was explained by the models. Subsequently correlation between standardized ERCS rates and VBAC rates was tested using Spearman's rank correlation test (reference p<0.05) (since the data was not normally distributed) and by visually inspecting the plot. Statistical analyses were performed using SPSS (SPSS version 20.0).

The Medical Ethical Committee (CMO) of Maastricht (Maastricht University Medical Center/ University of Maastricht) declared that no ethical approval was required for this study protocol, (MEC number 12-4-034). 


\section{Results}

We reviewed 9833 consecutive medical records, and 1068 women (11\%) had a history of CS of whom 763 (71\%) met the inclusion criteria. The baseline characteristics of this study cohort are shown in Table 1. On average, maternal age, ethnicity and having preeclampsia/HELLP or hypertension did not differ between ERCS and TOL.

In our cohort, 248 (33\%) women had an ERCS. The other 515 women (67\%) had a TOL of whom 371 (72\%) had a VBAC, resulting in a VBAC rate of $49 \%$. Women who underwent an ERCS had more often a prior CS due to failure to progress, had more often diabetes mellitus, and had a higher BMI or an EFW $\geq$ p90. Women who underwent an ERCS had less often a prior vaginal delivery or prior VBAC.

We entered all with univariate analyses preselected variables in the multivariate regression model in order to develop a model for correction for risk factors at patient level. These results are shown in Table 2. The variables that showed significance for correction for risk factors at patient level of the ERCS rates were pre-pregnancy BMI, prior non-progressive labor, prior VBAC and diabetes mellitus.

Table 3 shows the number of included deliveries per hospital, the observed ERCS rates, expected ERCS rates and standardized ERCS rates. Also, the mean differences between the expected and standardized rates are shown, which represent the amount of CS's that a hospital deviates from its expected rate when it would be presented with the mean patient population. Amongst the 17 participating hospitals, the crude observed ERCS rate was $29.8 \% \pm 11.8 \%$ (range $6.0 \%$ to $54.0 \%$ ). After correction for risk factors at patient level, $86.1 \%$ of the observed practice variation remained unexplained.

Pre-pregnancy BMI and a prior vaginal delivery were two significant variables for correction of VBAC-rates. These variables were significant in a multivariate model as well. These data are shown in more detail in Table 4.

Table 5 shows observed, expected and standardized VBAC rates and the amount that a hospital deviates from its expected rate when it would be presented with the mean patient population. Amongst the 17 included hospitals, the overall crude observed VBAC rate was $71.8 \% \pm 11.1 \%$ (range $50.0 \%$ to $90.0 \%$ ). After correction for risk factors at patient level, $85.3 \%$ of the observed practice variation remained unexplained. 
Table 1. Baseline characteristics of study population.

Characteristic $(n=763)$

Women

$n=763$

\begin{tabular}{|c|c|c|}
\hline Maternal age (years, mean \pm SD) & 32.5 & 4.5 \\
\hline \multicolumn{3}{|l|}{ Ethnicity, n/\% } \\
\hline Caucasian & 608 & 79.7 \\
\hline Mediterranean & 48 & 6.3 \\
\hline African & 30 & 3.9 \\
\hline Indo-Surinamese & 8 & 1.0 \\
\hline Asian & 19 & 2.5 \\
\hline Other & 23 & 3.0 \\
\hline Unknown & 27 & 3.5 \\
\hline Previous CS due to failure to progress, $n / \%$ & 336 & 44.0 \\
\hline Any previous vaginal delivery, $\mathrm{n} / \%$ & 152 & 19.9 \\
\hline Previous VBAC, $\mathrm{n} \%$ & 107 & 14.0 \\
\hline First trimester BMI $\left(\mathrm{kg} / \mathrm{m}^{2}\right.$, mean $\left.\pm \mathrm{SD}\right)$ & 26.1 & 5.9 \\
\hline PE6/HELLP, n/\% & 15 & 2.0 \\
\hline Hypertension, n/\% & 50 & 6.6 \\
\hline Diabetes mellitus, n/\% & 34 & 4.5 \\
\hline$E F W \geq p 90, n / \%$ & 22 & 2.9 \\
\hline Induction of labor, n/\% & 132 & $26 \mathrm{Na}$ \\
\hline Cervical dilation ( $\mathrm{cm}$, mean $\pm \mathrm{SD}$ ) & 3 & $\pm 2 \mathrm{Na}$ \\
\hline Cervical effacement $(\%$, mean \pm SD) & 64 & $\pm 19 \mathrm{Na}$ \\
\hline Fetal station $(B,-5-+5$, mean \pm SD) & -2 & $\pm 2 \mathrm{Na}$ \\
\hline
\end{tabular}

B, ballottement; BMI, body mass index; CS, cesarean section; EFW, estimated fetal weight; ERCS, elective repeat cesarean section; HELLP, HELLP syndrome - hemolysis, elevated liver-enzymes, low platelets; Na, not applicable; PE, pre-eclampsia; SD, standard deviation; TOL, trial of labor. 


\section{Missing data}

intended

TOL

$(n=515)$

n

$\begin{array}{ll}2 & 0,4 \\ 15 & 2.9\end{array}$

\section{ERCS}

( $n=248$ )
$\%$

$\begin{array}{ll}4 & 1.6 \\ 12 & 4.8\end{array}$

\begin{tabular}{llll}
0 & 0 & 0 & 0 \\
0 & 0 & 0 & 0 \\
0 & 0 & 0 & 0 \\
124 & 24.1 & 79 & 31.9 \\
0 & 0 & 2 & 0.8 \\
\hline 1 & 0.2 & 3 & 1.2 \\
\hline 2 & 0.4 & 1 & 0.4 \\
\hline 201 & 39.0 & 105 & 42.3 \\
0 & 0 & $\mathrm{Na}$ & - \\
11 & 2.1 & $\mathrm{Na}$ & - \\
\hline 56 & 10.9 & $\mathrm{Na}$ & - \\
57 & 11.1 & $\mathrm{Na}$ & - \\
\hline
\end{tabular}


Table 2. Overview of multivariate logistic regression model for predicting elective repeat cesarean delivery rates.

\begin{tabular}{llllll}
\hline Variable & Coefficient & SE & p-value & Odds ratio & $\mathbf{9 5 \% ~} \mathbf{C l}$ \\
\hline Intercept & -3.012 & 0.897 & 0.001 & 0.049 & - \\
Maternal age (years) & 0.034 & 0.023 & 0.144 & 1.034 & $0.989-1.082$ \\
Pre-pregnancy BMI (kg/m²) & 0.038 & 0.016 & 0.016 & 1.039 & $1.007-1.072$ \\
Prior non-progressive labor (yes/no) & 0.578 & 0.199 & 0.004 & 1.783 & $1.207-2.634$ \\
Prior VBAC (yes/no) & -1.454 & 0.399 & $<0.001$ & 0.234 & $0.107-0.510$ \\
Diabetes mellitus (yes/no) & 1.391 & 0.466 & 0.003 & 4.020 & $1.613-10.018$ \\
Hypertension (yes/no) & -0.550 & 0.406 & 0.175 & 0.577 & $0.260-1.278$ \\
\hline
\end{tabular}

BMI, body mass index; SE, standard error, VBAC, vaginal birth after cesarean

Table 3. Standardized elective repeat cesarean delivery rates per hospital type.

\begin{tabular}{|c|c|c|c|c|c|c|}
\hline $\begin{array}{l}\text { Hospital } \\
\text { type }^{a}\end{array}$ & $\begin{array}{l}\text { Hospital } \\
\text { number }\end{array}$ & $\begin{array}{l}\text { Included } \\
\text { deliveries }\end{array}$ & $\begin{array}{l}\text { Observed } \\
\text { rate }(\%)\end{array}$ & $\begin{array}{l}\text { Expected } \\
\text { rate }(\%)\end{array}$ & $\begin{array}{l}\text { Standardized } \\
\text { rate }(\%)\end{array}$ & $\begin{array}{l}\text { Mean difference } \\
(\%) \text { expected - } \\
\text { standardized }\end{array}$ \\
\hline 1 & 1 & 61 & 54.0 & 34.7 & 51.4 & -16.8 \\
\hline 1 & 2 & 51 & 39.0 & 33.3 & 38.7 & -5.5 \\
\hline 1 & 4 & 45 & 33.0 & 33.6 & 32.4 & 1.3 \\
\hline 1 & 12 & 55 & 38.0 & 34.7 & 36.1 & -1.4 \\
\hline 1 & 15 & 40 & 43.0 & 29.0 & 47.8 & -18.7 \\
\hline 2 & 5 & 28 & 32.0 & 33.9 & 31.1 & 2.8 \\
\hline 2 & 7 & 36 & 17.0 & 31.5 & 17.8 & 13.7 \\
\hline 2 & 9 & 39 & 28.0 & 30.6 & 30.2 & 0.5 \\
\hline 2 & 10 & 41 & 24.0 & 29.6 & 26.8 & 2.8 \\
\hline 2 & 11 & 48 & 35.0 & 32.9 & 35.1 & -2.2 \\
\hline 2 & 13 & 24 & 17.0 & 28.1 & 19.9 & 8.2 \\
\hline 2 & 16 & 42 & 26.0 & 31.7 & 27.1 & 5.7 \\
\hline 3 & 3 & 39 & 23.0 & 29.3 & 25.9 & 3.4 \\
\hline 3 & 6 & 100 & 41.0 & 32.4 & 41.8 & -9.4 \\
\hline 3 & 8 & 36 & 17.0 & 31.5 & 17.8 & 13.7 \\
\hline 3 & 14 & 46 & 35.0 & 31.9 & 36.2 & -4.2 \\
\hline 3 & 17 & 32 & 6.0 & 28.6 & 6.9 & 21.7 \\
\hline
\end{tabular}

a Hospital types: 1, non-teaching non-academic hospital; 2, teaching non-academic hospital; 3 , academic teaching hospital 
Table 4. Overview of multivariate logistic regression model for predicting vaginal birth after cesarean delivery rates.

\begin{tabular}{llllll}
\hline Variable & Coefficient & SE & p-value & Odds ratio & $\mathbf{9 5 \% \mathbf { ~ C l } ^ { \mathbf { 3 } }}$ \\
\hline Intercept & 1.886 & 1.259 & 0.134 & 6.591 & - \\
Maternal age (years) & -0.045 & 0.030 & 0.130 & 0.956 & $0.903-1.013$ \\
Pre-pregnancy BMI (kg/m²) & -0.047 & 0.021 & 0.025 & 0.954 & $0.916-0.994$ \\
Prior non-progressive labor (yes/no) & -0.426 & 0.259 & 0.100 & 0.653 & $0.393-1.085$ \\
Prior vaginal delivery (yes/no) & 1.612 & 0.402 & $<0.001$ & 5.011 & $2.278-11.026$ \\
Caucasian (yes/no) & 0.582 & 0.349 & 0.096 & 1.790 & $0.903-3.550$ \\
Cervical dilation (yes/no) & 0.104 & 0.067 & 0.122 & 1.110 & $0.973-1.267$ \\
Cervical effacement (yes/no) & 0.292 & 0.157 & 0.063 & 1.339 & $0.984-1.821$ \\
\hline
\end{tabular}

$\mathrm{BMI}$, body mass index; SE, standard error

Table 5. Standardized vaginal birth after cesarean rates per hospital type.

\begin{tabular}{lllllll}
\hline $\begin{array}{l}\text { Hospital } \\
\text { type }\end{array}$ & $\begin{array}{l}\text { Hospital } \\
\text { number }\end{array}$ & $\begin{array}{l}\text { Included } \\
\text { deliveries }\end{array}$ & $\begin{array}{l}\text { Observed } \\
\text { rate }(\%)\end{array}$ & $\begin{array}{l}\text { Expected } \\
\text { rate (\%) }\end{array}$ & $\begin{array}{l}\text { Standardized } \\
\text { rate (\%) }\end{array}$ & $\begin{array}{l}\text { Mean difference } \\
\text { (\%) expected - } \\
\text { standardized }\end{array}$ \\
\hline 1 & 1 & 28 & 60.7 & 72.1 & 60.7 & 11.4 \\
1 & 2 & 31 & 71.0 & 68.3 & 74.9 & -6.6 \\
1 & 4 & 30 & 83.3 & 74.5 & 80.7 & -6.2 \\
1 & 12 & 34 & 70.6 & 73.2 & 69.5 & 3.8 \\
1 & 15 & 23 & 50.0 & 68.5 & 54.9 & 13.6 \\
2 & 5 & 19 & 68.4 & 62.0 & 79.6 & -17.6 \\
2 & 7 & 30 & 86.7 & 77.1 & 81.1 & -4.0 \\
2 & 9 & 29 & 71.4 & 73.2 & 67.9 & 5.3 \\
2 & 10 & 31 & 86.7 & 70.1 & 89.1 & -19.0 \\
2 & 11 & 31 & 71.0 & 65.8 & 77.8 & -12.0 \\
2 & 13 & 20 & 90.0 & 71.2 & 91.2 & -19.9 \\
2 & 16 & 31 & 77.4 & 71.5 & 78.1 & -6.6 \\
3 & 3 & 30 & 70.0 & 72.3 & 69.8 & 2.5 \\
3 & 6 & 59 & 76.3 & 75.3 & 73.1 & 2.3 \\
3 & 8 & 30 & 56.7 & 73.4 & 55.7 & 17.8 \\
3 & 14 & 30 & 56.7 & 65.7 & 62.2 & 3.5 \\
3 & 17 & 30 & 73.3 & 70.1 & 75.5 & -5.4 \\
\hline
\end{tabular}

a Hospital types: 1, non-teaching non-academic hospital; 2, teaching non-academic hospital; 3, academic teaching hospital. 
Figures 1 and 2 show standardized ERCS rates and VBAC rates, respectively, per hospital type. Figure 1 illustrates that a wider range of ERCS rates exists amongst academic teaching hospitals. Also, the hospitals with the highest ERCS rates appear to be amongst the non-academic non-teaching hospitals. Figure 2 shows that with regard to VBAC, hospital types are more similar in terms of VBAC rates. The highest success rates appear to be amongst non-academic teaching hospitals.

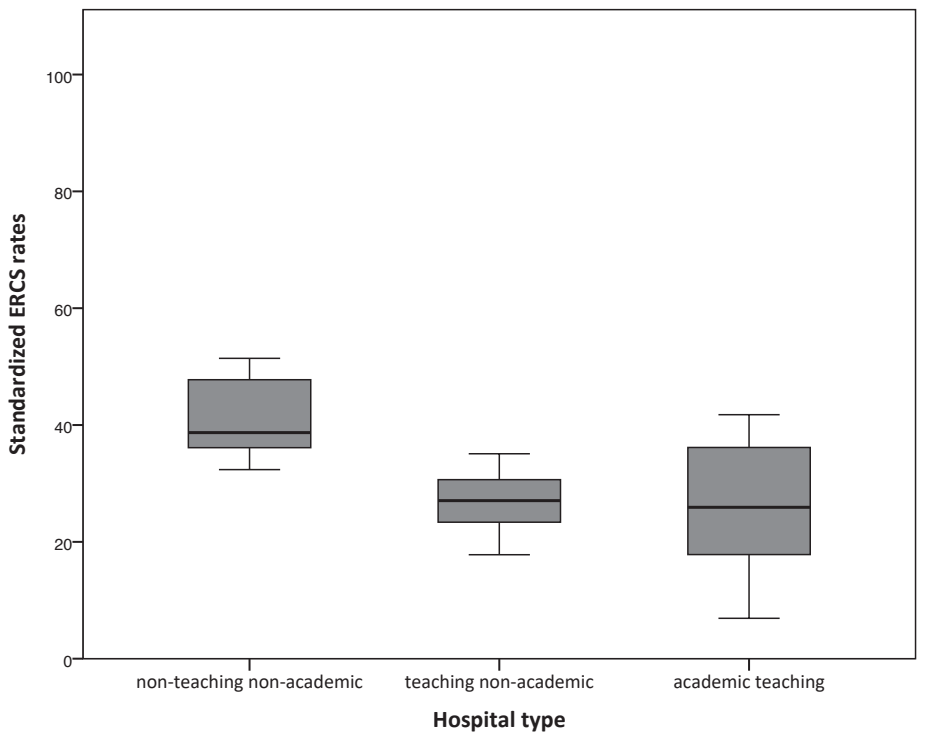

Figure 1. Standardized elective repeat cesarean section (ERCS) rate per hospital type.

Since data was not normally distributed, correlation was tested using the Spearman's rank correlation test. The test for correlation between ERCS and VBAC resulted in a rho of -0.46 with a p-value of 0.065 showing that there was a trend to a negative correlation between VBAC and ERCS (figure 3). 


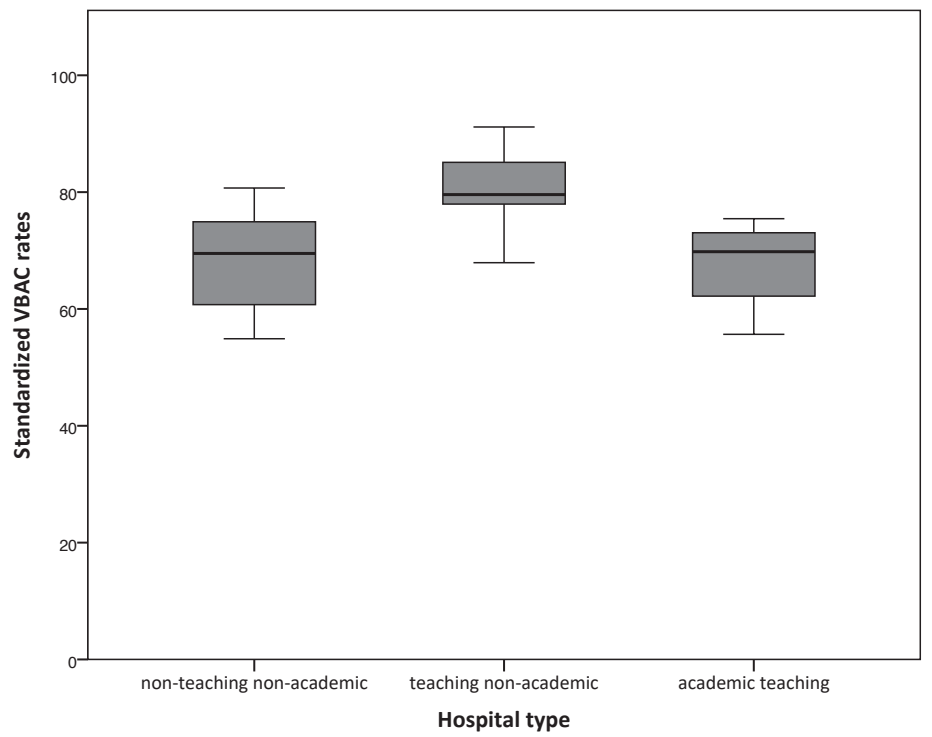

Figure 2. Standardized vaginal birth after cesarean (VBAC) rate per hospital type.

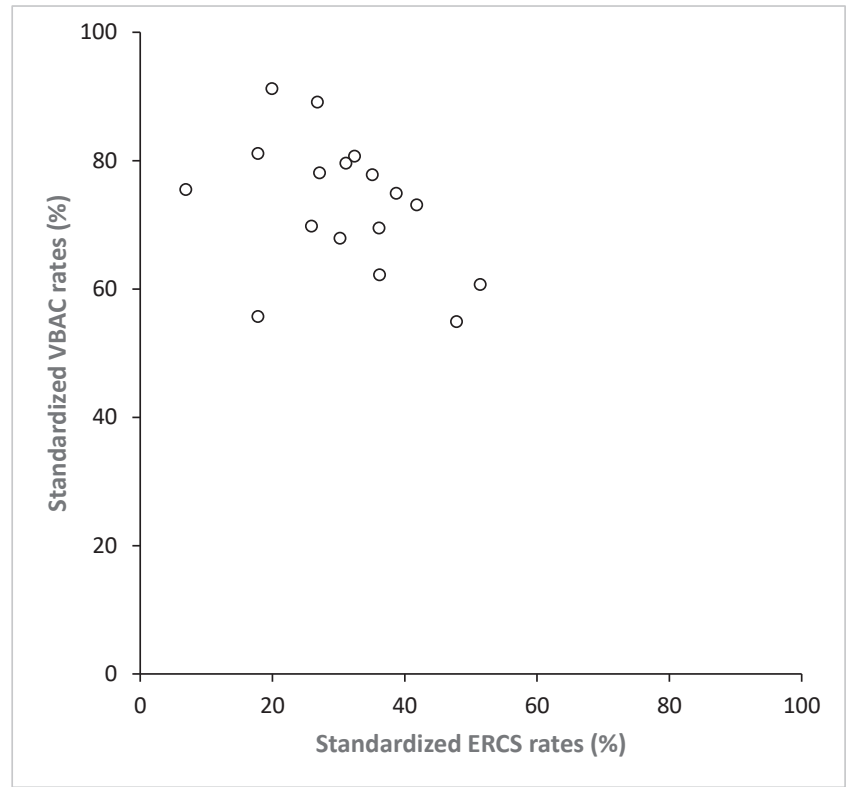

Figure 3. Correlation vaginal birth after cesarean (VBAC) and elective repeat cesarean section (ERCS) rates. 


\section{Discussion}

This study showed that in spite of the high VBAC rate, there is a striking amount of practice variation on mode of delivery after CS in the Netherlands regardless of risk factors at patient level. Amongst the 17 participating Dutch hospitals, ERCS rates corrected for these risk factors even varied between $6.9 \%$ and $51.4 \%$. For VBAC, this variation was less distinct but still $52.7 \%$ to $90.0 \%$. Yet, we showed that correcting for risk factors at patient level only partly explained the observed practice variation. Hence, the a priori risk of having a CS independent of woman's individual risk factors varies per hospital.

When estimating the effect of hospital type, it appeared that the largest variation exists amongst non-academic teaching hospitals. Furthermore, there was a trend towards a negative correlation between VBAC and ERCS. This implicates that hospitals tend to perform CS regardless of the probability of VBAC.

In line with other studies, our study showed a large variation in TOL rates between different hospitals $[6,7]$. Large variation in TOL rates is seen between countries, but at a national level there as well [6]. Even in a small country with high TOL rates as The Netherlands there is a remarkable amount of practice variation, comparable to countries with lower TOL rates [6]. Our results are in line with the cohort study of Kwee et al. in this study, performed in The Netherlands; practice variation was studied in 38 hospitals and showed a variation in TOL from 46 to 87\% [11].

The review of Guise et al reports a range in TOL rates from 28-70\% in the US [6]. TOL was more often performed in hospitals with a high birth-rate which are tertiary and teaching hospitals. They showed a large variation in VBAC as well from 52 to $85 \%$ in the US. However, the review of Guise included mainly studies performed in academic- and non-academic teaching hospitals [6]. Hence, this may cause a distorted view and the results may not be representative for non-academic non-teaching hospitals, because retrospective studies show TOL is less attempted in small non-academic non-teaching hospitals [15]. Our results confirm these findings and show 33-54\% in ERCS-rate in non-academic non-teaching hospitals compared to 6-41\% in academic- and non-academic teaching hospitals.

We can debate whether the observed ERCS rate is appropriate in relation to the type and abilities of specific hospitals. From the viewpoint of feasibility, it is understandable that obstetricians in small non-teaching non-academic hospitals rather perform an ERCS than a TOL as obstetric and theatre staffs are not on hand 24/7. In the United States, guidelines even advice that hospitals attempting VBAC require equipment and staff able to perform an emergency CS immediately [6]. 
At the same time, doctors have to cope with an increased risk of liability, which may result in a decreased performance of TOL [6]. Furthermore it may change the approach in counseling, despite the fact that contemporary guidelines state that women without a contra-indication should have a choice in mode of delivery and counseling is ideally discussed in a shared decision-making setting. These factors may influence or induce practice variation as well.

A strength of this study is that this is the first study to examine practice variation in vaginal birth after CS in a European country correcting for risk factors at patient level. We compared different levels of hospitals, from tertiary to small non-academic nonteaching hospitals. The distribution of the different levels of hospitals is representative for the national distribution. Another strength is that data selection occurred systematically by checking every single patient. In addition, the selection process of predictive variables for VBAC was in line with contemporary insights within prediction research $[8,9]$. We chose to correct only for predictive variables for VBAC as every woman should be counseled the same way. Furthermore, this study provides insight in on which level possible interventions would be meaningful.

A drawback of the chosen methodology, stepwise elimination for predictor selection is that it implies the risk of missing contributing predictors. For example, the predictor 'thickness of lower uterine segment' appears to be a probable independent predictor for failed TOL but was not taken into account during data-collection [16]. However, we expect this effect to be small since predictors were chosen based on contemporary literature. Another limitation is that, due to lack of data, we could not further specify the exact amount of practice variation that is derived from factors on hospital- and provider level. However, by performing an additional analysis in which we clustered types of hospital we were able to mainly visualize variation on hospital-level. Nevertheless, analysis by type of hospital is a rough measurement. Reasons for differences between hospital levels might be the presence of a theatre staffs $24 / 7$ or the total birth rate. These might be more specific measures. Clustering by types of hospital however still implies the assumption that hospitals within the clusters are comparable and is therefore less precise. Also, probably not all women are counseled the same way, suggesting large practice variation at provider level as well.

In our study we only performed analysis using patient level because we assumed practice variation correlates with risk factors at patient level. Future research could focus on multiple levels. Effects of availability of medical staff and level of experience, methods of counseling and shared decision making may play a role as well. The practice variation resulting from this can probably be reduced and the quality of healthcare can 
be enhanced by more structured general information. We developed a decision aid including a prediction model to calculate the probability of a patient having a VBAC [12, 17]. By implementing this decision aid in daily healthcare, and informing women about their chances and the risks, and benefits of both options in a structured way, reducing practice variation on patient level, provider level and hospital level might be possible.

In conclusion variation in mode of delivery after CS between hospitals is large and can only for the smaller part be explained by risk factors at patient level which might indicate that local policy plays a more important role in the derivation of practice variation. Hence in order to enhance guideline implementation and to reduce practice variation, further research is essential, in for example the benefit of better counseling and shared decision making by using the developed prediction model and decision aid is essential. 


\section{References}

1. National Institute for Health and Clinical Excellence. Clinical Guideline 132: Caesarean Section. London: RCOG, 2011.

2. ACOG. Vaginal birth after previous caesarean section. ACOG practice bulletin. Obstet Gynaecol. 2010; 116:450-63.

3. SOGC. Guidelines for Vaginal Birth After Previous Caesarean Birth. J Obstet Gynaecol Can. 2005(155):89: 319-31.

4. RCOG. Birth after previous caesarean birth. Green-top Guideline No 45. London RCOG, 2007.

5. NVOG - richtlijn Zwangerschap en bevalling na een voorgaande sectio caesarea. 2010. Available online at: http://www.nvog.nl (accessed 4 June, 2010)

6. Guise JM, Eden K, Emeis C, Denman MA, Marshall N, Fu RR, et al. Vaginal birth after caesarean: new insights. Evidence report/technology assessment 2010 (191): 1-397.

7. Toohill J, Gamble J, Creedy DK. A critical review of vaginal birth rates after a primary Caesarean in Queensland hospitals. Australian health review : a publication of the Australian Hospital Association 2013; 37(5): 642-8.

8. Harrell FJ. Regression Modeling Strategies. New York: Springer, 2001.

9. Steyerberg EW, Moons KG, van der Windt DA, Hayden JA, Perel P, Schroter S, et al. Prognosis Research Strategy (PROGRESS) 3: prognostic model research. PLoS medicine 2013; 10(2): e1001381.

10. Peduzzi P, Concato J, Kemper E, Holford TR, Feinstein AR, A simulation study of the number of events per variable in logistic regression analysis, J Clin Epidemiol. 1996:49:1373-9

11. Kwee A, Bots ML, Visser GH, Bruinse HW. Obstetric management and outcome of pregnancy in women with a history of caesarean section in the Netherlands. European journal of obstetrics, gynecology, and reproductive biology 2007; 132(2): 171-6.

12. Schoorel EN, van Kuijk SM, Melman S, et al. Vaginal birth after a caesarean section: the development of a Western European population-based prediction model for deliveries at term. BJOG 2014; 121(2): 194-201

13. Steyerberg EW. Clinical Prediction Models. New York: Springer, 2009.

14. Donders AR, van der Heijden GJ, Stijnen T, Moons KG. Review: a gentle introduction to imputation of missing values. Journal of clinical epidemiology 2006; 59(10): 1087-91.

15. Goldman G, Pineault R, Bilodeau H, Blais R. Effects of patient, physician and hospital characteristics on the likelihood of vaginal birth after previous caesarean section in Quebec. CMAJ : Canadian Medical Association journal = journal de l'Association medicale canadienne 1990; 143(10): 1017-24.

16. Kok N, Wiersma IC, Opmeer BC, de Graaf IM, Mol BW, Pajkrt E. Sonographic measurement of lower uterine segment thickness to predict uterine rupture during a trial of labour in women with previous Caesarean section: a meta-analysis. Ultrasound in obstetrics \& gynecology : the official journal of the International Society of Ultrasound in Obstetrics and Gynecology 2013; 42(2): 132-9.

17. Schoorel EN, Vankan E, Scheepers HC, et al. Involving women in personalized decision-making on mode of delivery after caesarean section: the development and pilot testing of a patient decision aid. BJOG 2014; 121(2): 202-9 


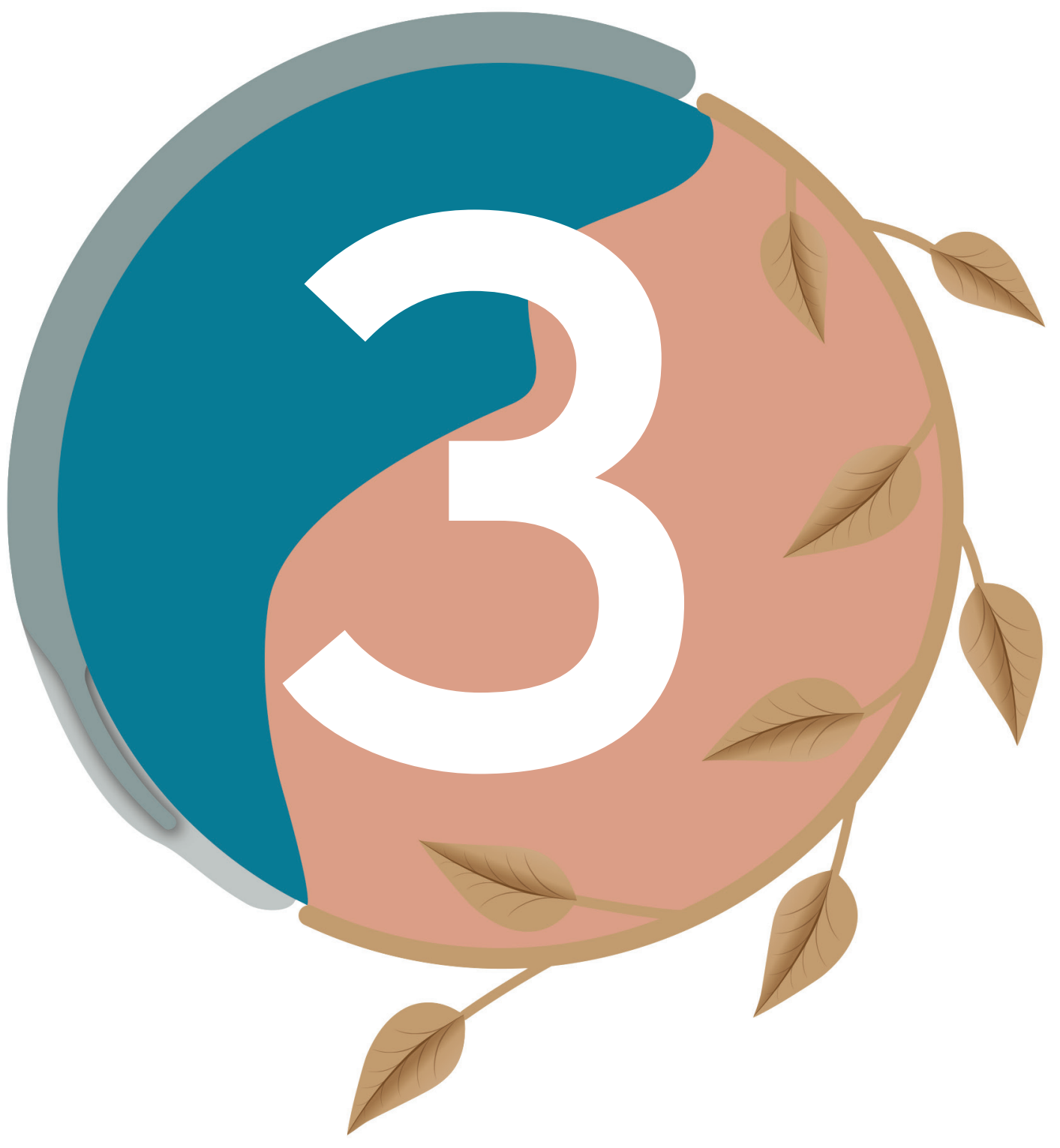




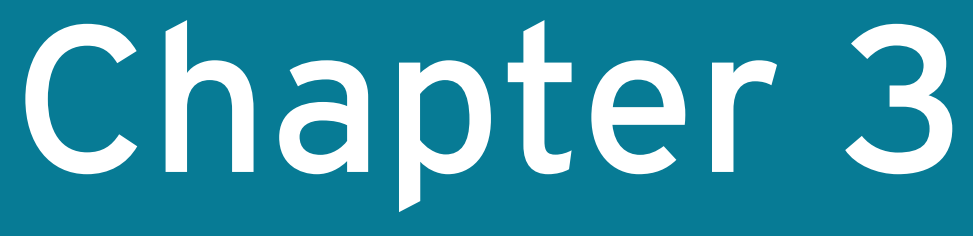

\section{Involving women in personalised decision-making on mode of delivery after caesarean section: the development and pilot testing of a patient decision aid}

ENC Schoorel, E Vankan, HCJ Scheepers, BCC Augustijn, CD Dirksen, M de Koning, SMJ van Kuijk, A Kwee, S Melman, JG Nijhuis, R Aardenburg, K de Boer, THM Hasaart, BWJ Mol, M Nieuwenhuijze, MG van Pampus, J van Roosmalen, FJME Roumen, R de Vries, MGAJ Wouters, T van der Weijden, RPMG Hermens BJOG: An international journal of Obstetrics and Gynaecology 2014;121:202-209 


\section{Abstract}

Objective: To develop a patient decision aid (PtDA) for mode of delivery after caesarean section (CS) that integrates personalised prediction of vaginal birth after caesarean (VBAC) with elicitation of patient preferences and evidence-based information.

Design: A PtDA was developed and pilot tested using the International Patients Decision Aid Standards (IPDAS) criteria.

Setting: Obstetric healthcare in the Netherlands.

Population: A multidisciplinary steering group, an expert panel and 25 future users of the PtDA, i.e. women with a previous CS.

Methods: Development consisted of a construction phase (definition of scope and purpose, selection of contents, framework and format) and a pilot-testing phase by interview. The process was supervised by a multidisciplinary steering group.

Main outcome measures: Usability, clarity, relevance.

Results: The construction phase resulted in a booklet including unbiased balanced information on mode of birth after CS, a preference elicitation exercise and tailored risk information including a prediction model for successful VBAC. During pilot testing, visualisation of risks and clarity formed the main basis for revisions. Pilot testing showed the availability of tailored structured information to be the main factor involving women in decision-making. The PtDA meets 39 out of 50 IPDAS criteria (78\%): 23 out of 23 criteria for content (100\%) and 16 out of 20 criteria for the development process ( $80 \%)$. Criteria for effectiveness $(n=7)$ were not evaluated.

Conclusions: An evidence-based PtDA was developed, with the probability of successful VBAC and the availability of structured information as key items. It is likely that the PtDA enhances the quality of decision-making on mode of birth after CS. 


\section{Introduction}

Decision-making in pregnancy is particularly complex because women must consider not only their own health but also that of their unborn babies. In the decision on mode of delivery after caesarean section (CS), the importance of involving and supporting pregnant women has been highlighted by various international guidelines [1-4]. When no contraindications are present, women should be provided with a choice between an elective repeat CS (ERCS) and an intended vaginal birth after caesarean (VBAC) (i.e. a trial of labour) [1-4]. It is recommended that this decision is based on a discussion of the risks, benefits and implications of both options [1-5]. Mean reported intended VBAC success rates are as high as 72-76\% [6], and a successful VBAC is associated with fewer major complications [7], a shorter recovery period and higher perceived maternal satisfaction scores $[8,9]$. In addition, an intended VBAC is in general more cost-effective than ERCS [10]. However the drawback of intended VBAC is possible failure leading to an emergency CS, which is associated with a higher risk of major complications including hysterectomy and operative injury [7], and lower levels of maternal satisfaction [8, 9] than with either ERCS or successful VBAC. The existence of major international differences in (intended) VBAC rates suggests that choices for mode of delivery after CS do not always reflect women's preferences but may result from nonmedical factors like hospital policy, concerns about medical liability or provider preference [6]. The question is how guideline recommendations on mode of birth after CS can be implemented in practice. Due to the complex nature of the decision-making process, and because it concerns a preference-sensitive decision, mode of delivery should be discussed within a shared-decision making (SDM) setting. SDM can be enhanced by the use of patient decision aids (PtDA), which provide unbiased information in a clear and comprehensive way. PtDAs have proven to be effective tools for facilitating communication between patient and healthcare provider and for increasing patients' knowledge and involvement [11]. Individualised prediction of successful intended VBAC may contribute to personalisation of the decision-making process and could place potential risks into context. Although there are several prediction models $[6,12,13]$ and two PtDAs $[14,15]$ on mode of birth after CS, there has as yet been no published integration of a prediction model with a PtDA. In this study we aim to develop and pilot test a PtDA for mode of delivery after previous CS that integrates personalised prediction of successful VBAC with clarification and elicitation of patient preferences and evidence-based information. 


\section{Methods}

\section{Construction of the PtDA}

The PtDA was developed using the systematic process illustrated in Figure 1 [16].

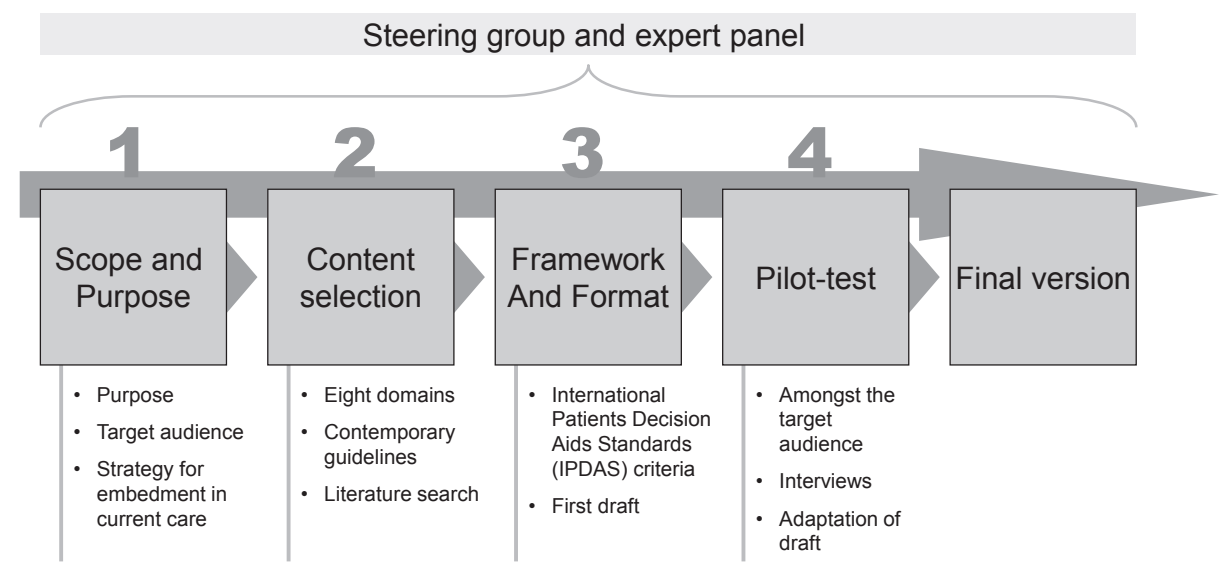

Figure 1 The process of developing the patient decision aid (PtDA) consisted of four steps: (1) definition of the scope and purpose of the PtDA, (2) content selection, (3) selection of the framework, format and decision support methods, and (4) pilot testing (i.e. alpha testing) of the prototype amongst the target audience. ${ }^{16}$ The development process was supervised by a steering group and a nationwide expert panel. The steering group consisted of two obstetricians and experts in epidemiology, shareddecision making and guideline implementation. The expert panel consisted of nine independent obstetricians, one midwife and one professor of midwifery science.

\section{Scope and purpose}

Its purpose was to improve decision-making on mode of birth after previous CS, as part of a guideline implementation strategy for the improvement of current Dutch care on CS [17]. The target audience, i.e. future users of the PtDA, were defined as pregnant women with a history of one previous CS without a contraindication for an intended VBAC. Contraindications were determined in accordance with current international guidelines on pregnancy and childbirth [1-5] and included: previous uterine rupture or other relevant uterine scar or a contraindication for vaginal labour such as malpresentation or placenta praevia [1-4]. It was decided not to include information in the PtDA on twin or breech pregnancies or in cases when more than one CS had already been performed, as we considered counselling in these cases to be essentially different. 


\section{Content selection}

Based on current international guidelines on pregnancy and childbirth after CS [1-5], literature and expert opinion, we identified eight domains to be important for decisionmaking on mode of birth after prior CS: (1) risks and (2) benefits of intended VBAC and ERCS, (3) induction of labour, (4) the consequences of the decision for future pregnancies, (5) predictors of successful intended VBAC, (6) the woman's preference for a vaginal or CS delivery, (7) the possibility of a birth plan (i.e. a document containing the woman's preferences when giving birth) and (8) previous birth experiences. Current guideline recommendations dictated the level of detail of the medical contents of domains 1 to 5 [1-5]. Current data on risk estimates was included, based upon the principle of best available evidence. For domain 5, a prediction model was included that estimates the probability of successful intended VBAC. This prediction model was developed by our research group in a western European cohort of women with high rate of intended VBAC. As prescribed by current methodological guidelines for prediction research, we selected potential predictors based on clinical reasoning and evidence from the literature $[18,19]$. The final set of predictors included in the model are: estimated foetal weight $\geq 90$ th percentile, previous CS due to failure to progress, previous vaginal delivery, induction of labour, pre-pregnancy body mass index and ethnicity. The development and internal validation of this prediction model is described elsewhere [20]. Domains 6,7 and 8 were elaborated based on expert opinion and a review of the literature.

\section{Selection of framework and format}

Based on the content selection, a practical framework was derived that consisted of the above mentioned eight domains. A prototype of the PtDA was developed in accordance with the international quality criteria of the International Patients Decision Aid Standards (IPDAS) [21]. More information regarding the selection process for the framework and the format can be found in Appendix S1 in the Supporting Information.

\section{Pilot testing and revision}

Pilot testing (i.e. alpha testing) comprised several rounds of review and revision of the prototype based on information gathered during development (MEC number 12-4-034). We recruited women in 2012 at an obstetric outpatient clinic of a Dutch university teaching hospital. Inclusion criteria were: pregnancy with a history of one CS and a current singleton cephalic pregnancy and a minimum age of 18 years. Women with a contraindication for an intended VBAC or who could not read Dutch were excluded. The primary outcome measures were usability, clarity, relevance of the content and relevance of the PtDA in general. After informed consent was obtained, women participated in a 30-minute face-to-face audio-recorded interview. The first part of the interview 
was unstructured according to the 'think aloud method' [22]. This method allowed us to obtain data using observation and without interrupting participants' thinking processes. The second part of the interview was conducted using a questionnaire. Issues of particular interest to us were the opinions of women on the stage at which the PtDA was introduced, opinions about the prediction model, whether there was a minimum outcome of the prediction model that women considered acceptable when deciding to try for a VBAC, unwanted adverse effects of the PtDA (such as increased anxiety), and opinions regarding the way in which risk was communicated and the preference elicitation tool.

The interviews were transcribed verbatim and translated into a thematic framework. Interviews were analysed by two independent researchers (ES and BA or MdK). Data collection and revision of the PtDA was continued over several rounds until data saturation was achieved. 


\section{Results}

\section{Construction of the PtDA}

The practical framework, i.e. the outline of the PtDA, was constructed on the basis of the selected medical contents and our eight domains. Due to the availability of an evidence-based report on birth after CS by Guise et al. [6], the quantification of risk was mainly based on data from meta-analyses. We included four additional papers because they either provided data that were more applicable for the target audience of the PtDA, based on population characteristics [23], were recently published and therefore not included in Guise et al.'s report [6] or were included in that report but not in the form of a meta-analysis [24]. The risk of uterine rupture was shown to range from 2.1 to 15 per 1000; we used 8 per 1000 (for spontaneous onset of labour) as a mean since this was more appropriate for the Dutch setting. This was based on data from a Dutch prospective cohort study [23] which reported a higher incidence (8 to 15 per 1000) of uterine rupture in women who attempt VBAC than was reported by the meta-analysis [6] (4.3 per 1000) and a recent large cohort study by Fitzpatrick et al. (2.1 per 1000) [25]. Our final selection of the risks of intended VBAC and ERCS is shown in Table 1.

The PtDA was subdivided into a general introduction, seven steps (chapters) that guide the decision-making process and a supplement that clarifies induction of labour after previous CS. The introduction to the PtDA describes its aim, explains the choice that has to be made regarding mode of delivery and lists the options.

- Step one of the PtDA consists of a question regarding any existing preference for either VBAC or ERCS before reading the PtDA. This enables the woman to identify preliminary thoughts, beliefs and decisions, but this preference can also be discussed with the provider.

- Step two includes two questions which can be used to evaluate previous birth experiences, fear of vaginal delivery and other external influences which the woman regards as relevant.

- In step three the woman is shown a fact sheet laying out the risks and benefits of both modes of delivery. Risks are illustrated by using pictographs on a scale of per 1000 women [26]. This level of detail with regard to the risks led us to give careful and extensive consideration to the method of risk visualisation. We derived several formats of the pictographs and elaborated these during pilot testing. Step three also includes the prediction model for successful intended VBAC. This element of the PtDA is shown in Figure 2. Providers enter variables into the prediction formula using a computerised calculator and the outcome is noted on the corresponding 
(empty) pictograph within the PtDA. In order to provide context to the outcome of the prediction model, a mean probability of 70-75\% of successful VBAC is included $[1,23]$. All risks and benefits are explained using plain language, pictographs and summaries, in a balanced, unbiased manner.

Table 1. Risks of intended vaginal birth after caesarean and elective repeat caesarean section: estimates that were selected for the contents of the patient decision aid based on literature research.

\begin{tabular}{|c|c|c|}
\hline Risk & Intended VBAC & ERCS \\
\hline Maternal mortality & 0.04 per $1000^{6}$ & 0.13 per $1000^{6}$ \\
\hline Severe maternal morbidity* & $\begin{array}{l}2 \text { per } 1000(\mathrm{VBAC})^{7} \\
38 \text { per } 1000(\mathrm{CS})^{7}\end{array}$ & 8 per $1000^{7}$ \\
\hline Uterine rupture, general & $\begin{array}{l}8 \text { per } 1000 \text { (range } 2.0 \text { to } 15 \text { per } \\
1000)^{6,23,24}\end{array}$ & 0.3 per $1000^{6}$ \\
\hline \multicolumn{3}{|l|}{ Uterine rupture, IOL: } \\
\hline Prostaglandins & 20 per $1000^{6}$ & NA \\
\hline Oxytocin & 11 per $1000^{6}$ & NA \\
\hline \multicolumn{3}{|c|}{$\begin{array}{l}\text { Future pregnancies, risk per number } \\
\text { of previous CS: }\end{array}$} \\
\hline Placenta praevia & NA & $\begin{array}{l}\text { 2: } 17 \text { per } 1000^{6} \\
\text { 3: } 30 \text { per } 1000^{6}\end{array}$ \\
\hline Placenta accreta & NA & $\begin{array}{l}\text { 2: } 6 \text { per } 1000^{25} \\
\text { 3: } 21 \text { per } 1000^{25}\end{array}$ \\
\hline Hysterectomy & NA & $\begin{array}{l}\text { 2: } 9 \text { per } 1000^{25} \\
\text { 3: } 24 \text { per } 1000^{25}\end{array}$ \\
\hline ICU admission & NA & $\begin{array}{l}2: 5 \text { per } 1000^{25} \\
\text { 3: } 16 \text { per } 1000^{25}\end{array}$ \\
\hline Blood transfusion $\geq 4$ units & NA & $\begin{array}{l}2: 8 \text { per } 1000^{25} \\
\text { 3: } 16 \text { per } 1000^{25}\end{array}$ \\
\hline Operative injury** & NA & $\begin{array}{l}2: 13 \text { per } 1000^{25} \\
\text { 3: } 24 \text { per } 1000^{25}\end{array}$ \\
\hline Neonatal mortality & 1.3 per $1000^{6}$ & 0.5 per $1000^{6}$ \\
\hline Severe neonatal morbidity & No evidence for a significant difference & in the long term ${ }^{6}$ \\
\hline
\end{tabular}

*Composite of uterine rupture, hysterectomy and surgical injury; **Composite of cysthotomy, bowel injury, uretheral injury and bowel obstruction. CS, caesarean section; VBAC, vaginal birth after caesarean section; ERCS, elective repeat $C S$; IOL, induction of labour; ICU, intensive care unit; NA, not applicable. 


\section{What is my chance of a vaginal birth?}

The total risk of complications is smaller for women with a vaginal delivery. An average of 70 to 75 percent of the women who start labour with the intention to have a vaginal delivery succeed.

\section{Calculator: your individual chance of a vaginal delivery (>32 weeks gestational age)}

At 32 weeks gestational age we can calculate your chance of a successful vaginal birth based on your medical history and current medical condition. Your gynaecologist will calculate your individual chance during consultation.

\section{If you choose for an intended vaginal delivery, your chance of a successful vaginal delivery is:}

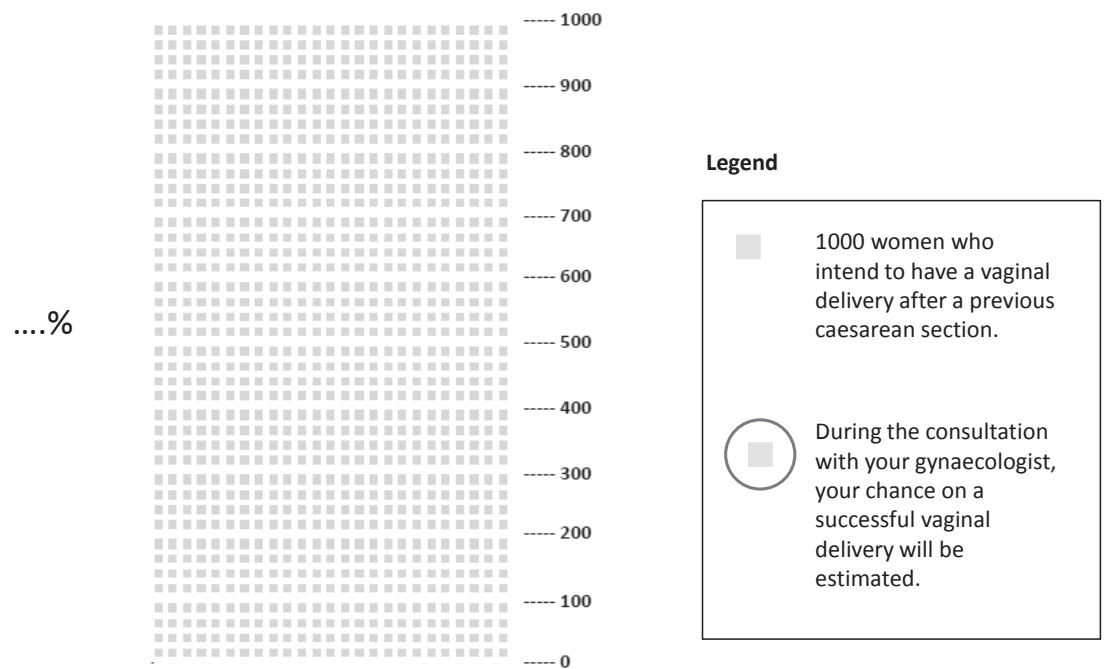

When labour starts before the estimated date of delivery, the chance of a successful vaginal delivery might be increased. However, when labour must be induced, the chance of a successful vaginal delivery is to some extent decreased. Therefore, when the medical conditions change, the calculator needs to be re-entered.

Figure $\mathbf{2}$ Prediction model for successful intended vaginal birth after caesarean. This is the element of the patient decision aid that explains the prediction model and can be used to show the individualised probability of successful intended vaginal birth after caesarean. 
Step four involves a preference elicitation tool, which was designed as a list of statements that women (and their partners) can consider to clarify their values and thoughts around several aspects of the decision. The statements can be scored on a four-point Likert scale to show level of agreement with the statements. Statements were derived from the entire contents of the PtDA and were completed with data from qualitative studies of women's views on deciding about mode of birth after CS [27, 28]. The preference elicitation tool can be viewed in Appendix S2.

- $\quad$ Step five of the PtDA explains the option of making agreements on the delivery (birth plan), such as an epidural analgesia. This step facilitates discussion of a birth plan between the woman and healthcare provider.

- $\quad$ Step six requires is preliminary decision.

- $\quad$ Step seven is aimed to encourage the woman and healthcare provider to agree on follow-up.

- In the supplement, induction of labour after CS is considered: risks and methods of induction are explained and this encourages recalculation of the probability of successful intended VBAC.

\section{Pilot testing and revision}

\section{Pilot one}

In total, 16 eligible women with a history of one previous CS were included in the first pilot. The baseline characteristics are described in Table 2. The mean age of the participants was 33 years; all were native Dutch speakers and 14 out of 16 (87\%) had the median socio-economic status (SES). Pilot one consisted of three rounds in which interviews were conducted and the PtDA was revised. The majority of the revisions concerned wording and clarity. Many women stated that they experienced a lack of information within the current care set-up. With regard to timing of exposure to the PtDA, a range of 12 weeks gestational age to 36 weeks gestational age was considered appropriate. Further, 15 out of 16 participants thought that the outcome of the prediction model for successful intended VBAC helped their decision-making process. Two women would choose an ERCS if their predicted probability of successful VBAC was $50 \%$ or less, and one woman set the cut-off value at 60-65\%. Thirteen women noted that they could not define a minimum outcome of the prediction model that they considered acceptable for trying a VBAC.

In general, all women thought that the PtDA was clear and informative. The PtDA was considered relevant by all participants. The stepwise approach of the decision-making process was repeatedly cited as a positive point. Also, most women felt that the PtDA 
was complete, balanced and objective. An aspect that was repeatedly mentioned to require improvement was the pictographs of the health outcomes. In rounds one and two, many women stated that one or more of the pictographs did not clarify the risks. They thought that the pictographs were distracting and added nothing to the decisionmaking process. In the third round, women thought that the presented figures were clear, but two out of seven women still thought that the pictures could be omitted.

In the third round of pilot one, no new information was obtained. Subsequently, we presented the PtDA to an expert panel for critical review and comments. Eight out of 11 experts approved this version. However, three out of 11 experts expressed concerns regarding the presentation of risks. A new outline was suggested for the pictographs that involved using cubes instead of pregnant women and means instead of ranges [26]. Based on this feedback, the PtDA was revised and this new version was tested in pilot two.

\section{Pilot two}

Nine eligible women were included. The baseline characteristics are summarized in Table 2 . The mean age of the participants was 36 years; eight out of nine (89\%) women were native Dutch speakers and four out of nine (44\%) had the median SES.

\begin{tabular}{|c|c|c|}
\hline Characteristic & Pilot one $(n=16)$ & Pilot two $(n=9)$ \\
\hline Maternal age (years, mean \pm SD) & $33 \pm 3$ & $36 \pm 4$ \\
\hline Native Dutch speakers ( $n, \%)$ & $16(100)$ & $8(89)$ \\
\hline \multicolumn{3}{|l|}{ Socio-economic status* $(n, \%)$} \\
\hline High & $2(13)$ & $1(11)$ \\
\hline Median & $14(87)$ & $4(44)$ \\
\hline Low & $\mathrm{O}(0)$ & $2(22)$ \\
\hline Unknown & $\mathrm{O}(0)$ & $2(22)$ \\
\hline \multicolumn{3}{|l|}{ Previous CS $(n, \%)$} \\
\hline Emergency CS & $10(63)$ & $5(56)$ \\
\hline Planned CS & $6(38)$ & $4(44)$ \\
\hline Previous vaginal delivery $(n, \%)$ & $2(13)$ & $1(11)$ \\
\hline \multicolumn{3}{|l|}{ Preferred mode of birth } \\
\hline Intended VBAC & $12(75)$ & $5(56)$ \\
\hline ERCS & $4(25)$ & $4(44)$ \\
\hline
\end{tabular}

SD, standard deviation; CS, caesarean section; VBAC, vaginal birth after caesarean section; ERCS, elective repeat CS. *Derived from post-code related socio-economic status scores, based on data on income, educational level and profession. 
Pilot two resulted in minor additional changes regarding the wording and clarity of the PtDA. The revised pictographs were considered clear, and seven out of nine women thought that the pictographs supported the information in the tables. Eight out of nine women thought that the PtDA was relevant. After pilot two, no major revisions were required. After final adjustments were made, the PtDA was presented to the expert panel. The PtDA was approved by all members of the expert panel.

\section{IPDAS criteria}

We used the checklist of the IPDAS collaboration $[21,29]$ to estimate the quality of the developed PtDA. Of the 64 items on the checklist, 50 quality criteria were applicable to our study based on the scope of the PtDA. The final version of the PtDA met 39 out of the 50 applicable IPDAS criteria (78\%) [21, 29]. With regard to content, all 23 criteria were met. For the domain development process, we met 16 out of 20 criteria. The four criteria that we did not meet were whether the PtDA is written according to a validated readability score (10.4) and if the PtDA is understood by those with limited reading skills (10.6). Though we pilot tested the PtDA, we did not actually field test (i.e. beta test) the PtDA in the current study $(1.4,1.5)$. The effectiveness of the PtDA was not evaluated in the current development study; therefore we have not yet met the seven criteria (12.1-12.8) concerning effectiveness. 


\section{Discussion}

\section{The main findings}

The current study provides insight in the systematic process of developing a decisionsupport tool by means of interdisciplinary cooperation of healthcare professionals and the critical input of future users, i.e. women and healthcare providers. The agreed format is a booklet with a stepwise approach for decision-making. Opinions on the stage at which women should be introduced to the PtDA varied widely between individual women and providers. Therefore, we agreed on introduction at any gestational age before 36 weeks based on the needs of the woman concerned. The PtDA is evidence based and its content is in agreement with current recommendations and guidelines. Hence, this PtDA could be seen as a guideline implementation tool. The quantification of risks was mainly based on data from meta-analyses. Though no studies on this topic with a grade A level of evidence were available, many large cohort studies provide insight into relevant risks. The need for structured information was confirmed, as women indicated that clear and relevant information is currently hard to find. Women emphasized the clarity of the step-wise approach to decision-making and of the preference elicitation tool. As risks had to be shown on a scale per 1000 women, several versions of the pictographs had to be pilot tested. Thanks to the critical input of women and healthcare experts, we established a format that was usable and clear. The pilot study confirmed that women value the use of a prediction model for decision-making, though many women could not define a minimum outcome of the prediction model that they considered acceptable for trying a VBAC. However, our results cannot directly show the impact that application of the prediction model will have on women's choices. Actual application of the prediction model requires the woman and the gynaecologist to interpret the outcome of the prediction model together, and this is necessary in order to measure its effect. Based on the results of pilot testing, it is likely that this PtDA supports the decision-making process, but results on the effectiveness of the strategy have to be further explored.

\section{Strengths and weaknesses}

We developed the PtDA according to a thorough systematic approach. Quality control was performed using critical input and review of the expert panel. The opinions of 25 women amongst the target audience were taken into account during development. However, readers may question the representativeness of the pilot study since it was performed in just one tertiary hospital and only included a small number of women with a low SES. We acknowledge that results should be confirmed in other settings with a larger study population. Other drawbacks of our design are that we did not specifically test the PtDA embedded within the routine clinical pathway (field testing). Also, we did 
not target women with limited reading skills, and this may have influenced attitudes about the pictographs, for example. Therefore, the results of this pilot study should be interpreted with caution and should be confirmed and complemented by the results of a larger, prospective trial.

\section{Interpretation}

Two other PtDAs on mode of birth after CS have been published. The PtDA of Shorten et al.[14] was published in 2004 and comprised a booklet with a value clarification exercise. A systematic review conducted by Vlemmix et al. estimated the agreement of published obstetrics PtDAs with the IPDAS criteria [30]. According to this review, the PtDA of Shorten et al. meets 34 of 50 IPDAS criteria [30]. Another PtDA, developed by Emmett et al. and published in 2007 [15], comprised a computerised information programme with a decision analysis tool. This PtDA meets 29 of 50 IPDAS criteria [30]. In the current study, we were able to meet 39 out of 50 applicable IPDAS criteria, which compares well with other PtDAs in obstetrics [31], especially when taking into account that effectiveness criteria ( $n=7$ ) will be further explored in ongoing research. Our PtDA has similarities to other available PtDAs on delivery after CS [14, 15] in the choice of key issues that are addressed. However, our PtDA also provides a new decisionmaking element, namely the integration of an individualised estimation of intended VBAC success with evidence-based information. We consider the prediction model to be applicable to other western European populations with comparable VBAC rates and ethnicities. With regard to other specific information on risk estimates, the PtDA should be evaluated along local guidelines and literature since differences in obstetric policy and case-mix may impair the validity of the data. Hence, the PtDA can be adapted for different populations.

We expect that the introduction of our PtDA in current care will enhance the involvement of women in decision-making on mode of delivery after CS. Subsequently it is hoped that this will reduce decisional conflicts and increase patient satisfaction. Application of the prediction model might alter birth preferences and reduce emergency CS; if this effect is observed we would expect that a reduction in major maternal and neonatal morbidity. Before this PtDA can be incorporated into current care, its effectiveness needs to be ascertained in a controlled prospective trial. Currently, a prospective trial amongst 12 Dutch hospitals is being carried out in order to determine its effectiveness in terms of CS rates, adherence to guidelines, decisional conflict, patient satisfaction, feasibility and costs (SIMPLE TRIAL: NCT00800384). 


\section{Conclusion}

This paper provides insight into the systematic development of a PtDA that aims to enhance the involvement of women in decision-making on mode of delivery after CS. It has uncovered the main issues around the involvement of women in decision-making, namely the medical and nonmedical items that women and experts consider relevant for decision-making, the method of communicating risks, the additive value of using a prediction model for successful intended VBAC and the stage at which women are introduced to the PtDA. The need for a healthcare strategy for mode of delivery after CS was confirmed. In the current format the PtDA is applicable for western European countries, and specific information with regard to risk estimates may be adapted for different populations. The pilot study suggests that the PtDA and the included prediction model support the decision-making process. Its effectiveness in terms of CS rates, adherence to guidelines, decisional conflict, patient satisfaction, feasibility and costs will be further examined in a prospective controlled trial. 


\section{References}

1. Dutch Society of Obstetrics and Gynaecology. Guideline: Pregnancy and Childbirth after previous caesarean section. 2010.

2. RCOG. Birth after previous caesarean birth. Green-top Guideline. 2007;No. 45.

3. SOGC. Guidelines for Vaginal Birth After Previous Caesarean Birth. J Obstet Gynaecol Can. 2005(155):89: 319-31.

4. ACOG. Vaginal birth after previous cesarean delivery. ACOG practice bulletin. 2010(no. 115).

5. National Institute for health and Clinical Excellence: Caesarean Section. NICE clinical guideline 132. 2011 (last modified 2012)

5. National Institutes of Health Consensus Development Conference Statement vaginal birth after cesarean: new insights March 8-10, 2010. Semin Perinatol 2010; 34(5): 351-65.

6. Guise JM, Eden K, Emeis C, et al. Vaginal birth after cesarean: new insights. Evid Rep Technol Assess (Full Rep) 2010; (191): 1-397.

7. McMahon MJ, Luther ER, Bowes WA, Jr., Olshan AF. Comparison of a trial of labor with an elective second cesarean section. N Engl J Med 1996; 335(10): 689-95.

8. Shorten A, Shorten B. The importance of mode of birth after previous cesarean: success, satisfaction, and postnatal health. J Midwifery Womens Health 2012; 57(2): 126-32.

9. Shorten A, Shorten B, Keogh J, West S, Morris J. Making choices for childbirth: a randomized controlled trial of a decision-aid for informed birth after cesarean. Birth 2005; 32(4): 252-61.

10. Fawsitt CG, Bourke J, Greene RA, Everard CM, Murphy A, Lutomski JE. At What Price? A CostEffectiveness Analysis Comparing Trial of Labour after Previous Caesarean versus Elective Repeat Caesarean Delivery. PLoS One 2013; 8(3): e58577.

11. Stacey D, Bennett $C L$, Barry MJ, et al. Decision aids for people facing health treatment or screening decisions. Cochrane database of systematic reviews 2011; (10): CD001431.

12. Grobman WA. Rates and prediction of successful vaginal birth after cesarean. Semin Perinatol 2010; 34(4): 244-8.

13. Eden KB, McDonagh M, Denman MA, et al. New insights on vaginal birth after cesarean: can it be predicted? Obstet Gynecol 2010; 116(4): 967-81.

14. Shorten A, Chamberlain M, Shorten B, Kariminia A. Making choices for childbirth: development and testing of a decision-aid for women who have experienced previous caesarean. Patient Educ Couns 2004; 52(3): 307-13.

15. Emmett CL, Murphy DJ, Patel RR, et al. Decision-making about mode of delivery after previous caesarean section: development and piloting of two computer-based decision aids. Health Expect 2007; 10(2): 161-72

16. Coulter A, Stilwell D, Kryworuchko J, Dolan Mullen P, Ng C, van der Weijden TA. systematic development process for patient decision aids.. Prov accepted BMC Med Infor Dec Mak 2013; ; Suppl.

17. Melman S, Schoorel EN, Dirksen C, et al. SIMPLE: implementation of recommendations from international evidence-based guidelines on caesarean sections in the Netherlands. Protocol for a controlled before and after study. Implement Sci 2013; 8: 3.

18. Steyerberg E. Clinical Prediction Models. New York: NY: Springer; ; 2009.

19. Harrell F. Regression Modeling Strategies. New York: NY: Springer; 2001.

20. Schoorel ENC, van Kuijk SMJ, Melman S, Nijhuis JG, Smits LJM, Aardenburg R. Personalized estimation of successful intended vaginal delivery after caesarean: the development of a WesternEuropean population based prediction model Submitted for publication, BJOG, themed issue 2013. 
21. Elwyn $G$, O'Connor A, Stacey $D$, et al. Developing a quality criteria framework for patient decision aids: online international Delphi consensus process. Bmj 2006; 333(7565): 417.

22. Lundgren-Laine H, Salantera S. Think-aloud technique and protocol analysis in clinical decisionmaking research. Qualitative health research 2010; 20(4): 565-75.

23. Kwee A, Bots ML, Visser GH, Bruinse HW. Obstetric management and outcome of pregnancy in women with a history of caesarean section in the Netherlands. Eur J Obstet Gynecol Reprod Biol 2007; 132(2): 171-6.

24. Silver RM, Landon MB, Rouse DJ, et al. Maternal morbidity associated with multiple repeat cesarean deliveries. Obstet Gynecol 2006; 107(6): 1226-32.

25. Fitzpatrick KE, Kurinczuk JJ, Alfirevic Z, Spark P, Brocklehurst P, Knight M. Uterine rupture by intended mode of delivery in the UK: a national case-control study. PLoS Med 2012; 9(3): e1001184.

26. Zikmund-Fisher BJ, Ubel PA, Smith DM, et al. Communicating side effect risks in a tamoxifen prophylaxis decision aid: the debiasing influence of pictographs. Patient Educ Couns 2008; 73(2): 209-14.

27. Kaimal AJ, Kuppermann M. Understanding risk, patient and provider preferences, and obstetrical decision making: approach to delivery after cesarean. Semin Perinatol 2010; 34(5): 331-6.

28. Emmett CL, Montgomery AA, Murphy DJ. Preferences for mode of delivery after previous caesarean section: what do women want, what do they get and how do they value outcomes? Health Expect 2011; 14(4): 397-404.

29. Elwyn G, O'Connor AM, Bennett $C$, et al. Assessing the quality of decision support technologies using the International Patient Decision Aid Standards instrument (IPDASi). PLoS One 2009; 4(3): e4705.

30. Vlemmix F, Warendorf JK, Rosman AN, et al. Decision aids to improve informed decision-making in pregnancy care: a systematic review. BJOG 2013; 120(3): 257-66.

31. Knol F, Boelhouwer J, Veldheer V. Neighbourhood status development in the Netherlands 19982010. The Netherlands institute for social research 2012.

32. Elwyn G, Lloyd A, Joseph-Williams N, et al. Option Grids: shared decision making made easier. Patient Educ Couns 2013; 90(2): 207-12. 


\section{Appendix S1. Selection of the framework and format of the 'PtDA'.}

Based on the content selection, a practical framework was derived that consisted of the defined eight domains. Several examples of existing PtDAs were studied in order to select the appropriate format and decision support method. An important criterion for selection of format and decision support method was usability and applicability within current care. After construction of the framework and selection of the format and decision support methods, a prototype of the PtDA was developed in accordance with the international quality criteria of the International Patients Decision Aid Standards (IPDAS) [21] The practical framework, i.e. outline of the PtDA, was constructed based on the selected medical contents. Subsequently, several possible formats were discussed: an online program, a booklet and an option grid [32]. It was decided that a booklet was most compatible with current care. We used the checklist of the IPDAS collaboration $[20,26]$ in order to complete the outline of the PtDA and to derive the format of the PtDA. 


\section{Appendix S2. Preference elicitation tool.}

This preference elicitation tool of the patient decision aid can be used for value clarification and establishing preferences on both options of mode of birth after prior caesarean section (intended vaginal birth after caesarean or elective repeat caesarean section).

\begin{tabular}{|c|c|c|c|c|}
\hline What is important to you (and your partner)? & 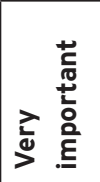 & 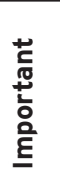 & 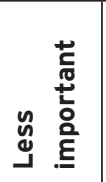 & 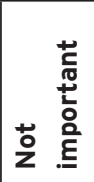 \\
\hline \multicolumn{5}{|l|}{ In a vaginal delivery } \\
\hline $\begin{array}{l}\text { 1. I feel more involved in the birth of my baby } \\
\text { 2. I will experience a normal childbirth } \\
\text { 3. The birth will occur the natural way } \\
\text { 4. I will experience pain/contractions during labour } \\
\text { 5. I have less control of the labour process } \\
\text { 6. Episiotomy or tearing might happen } \\
\text { 7. There is a risk of an (emergency) caesarean section } \\
\text { 8. The quantity of my individual chance of a successful vaginal } \\
\text { delivery }\end{array}$ & & & & \\
\hline \multicolumn{5}{|l|}{ In a caesarean section } \\
\hline $\begin{array}{l}\text { 9. I have more control of when and how the delivery takes place. } \\
\text { 10. There is definitely an operation } \\
\text { 11. I will experience pain after the surgery } \\
\text { 12. There is a higher chance of complications like thrombosis, } \\
\text { infection and bleedings. }\end{array}$ & & & & \\
\hline \multicolumn{5}{|l|}{ Severe risks } \\
\hline $\begin{array}{l}\text { 13. In a vaginal delivery, there is a larger risk of a rupture of the } \\
\text { scar in the uterus (uterine rupture). } \\
\text { 14. The overall chance of severe complications for the mother in } \\
\text { a vaginal delivery is smaller. } \\
\text { 15. In a caesarean section, there is a little higher chance of death } \\
\text { of the mother. } \\
\text { 16. For a vaginal delivery and a caesarean section, the chance of } \\
\text { permanent injuries for the baby is the same. } \\
\text { 17. In a caesarean section, the chance of death of the baby is a } \\
\text { little smaller. } \\
\text { 18. Every new caesarean section increases risks for a future } \\
\text { pregnancy. }\end{array}$ & & & & \\
\hline \multicolumn{5}{|l|}{ After a vaginal delivery } \\
\hline \multicolumn{5}{|l|}{$\begin{array}{l}\text { 19. I will probably recover faster. } \\
\text { 20. I will probably return to home earlier. }\end{array}$} \\
\hline 21. Other important considerations & & & & \\
\hline
\end{tabular}




\section{Appendix S3. Decision Aid}

\section{Delivery after a previous caesarean section: making a joint decision using a decision aid}

This decision aid is intended for pregnant women who have had a caesarean section in a previous pregnancy. A decision will have to be made together with your partner and gynaecologist about the delivery method for the current pregnancy: to strive for a vaginal delivery or choose for a planned caesarean section. The table below sets out the options and what they involve.

\begin{tabular}{|l|l|l|}
\hline & Vaginal delivery & Planned caesarean section \\
\hline $\begin{array}{l}\text { What does this } \\
\text { involve? }\end{array}$ & $\begin{array}{l}\text { You deliver in hospital with } \\
\text { constant monitoring of the baby } \\
\text { (CTG). } \\
\text { If the baby can't be delivered } \\
\text { vaginally, then a(n) (emergency) } \\
\text { caesarean section is performed. }\end{array}$ & $\begin{array}{l}\text { The baby is born at 39 weeks with } \\
\text { a planned operation. }\end{array}$ \\
\hline
\end{tabular}

We strive towards making a timely provisional decision together with your gynaecologist. Naturally changes can still occur later in the pregnancy that can change this decision. This means that the delivery method will be discussed with you once again between weeks 38 and 40 .

Using a step-by step plan, you will be discussing the important points for choosing between a vaginal delivery or a planned caesarean section with your gynaecologist. These points of discussion are:

1. your possible preference before the meeting

2. your experiences with a previous delivery

3. information about the pros and cons and possible complications of a vaginal delivery and a planned caesarean section.

4. your considerations for weighing up the two options

5. the wishes and/or conditions under which you would decide on a vaginal delivery

6. a provisional decision

7. what next? 


\section{Step 1}

It is possible you already have a preferred choice before going through this decision aid. What is your current preference?

$\square$ Vaginal delivery

$\square$ Planned caesarean section

$\square$ Not applicable, I have no preference as yet

\section{Step 2 My own experience}

Do experiences of your past delivery/deliveries play a part in your decision?

What are other important factors that are influencing your decision on this delivery, such as experiences in your immediate environment? 


\section{Step 3 Comparing}

In step 3, the pros and cons and risks of a vaginal delivery and a planned caesarean section are discussed. Some disadvantages of a planned caesarean section also occur when women who, in the end, still need $a(n)$ (emergency) caesarean section. The table below offers a general overview of what a vaginal delivery or a planned caesarean section can mean for mother, baby and the post-natal period. The chance of complications and the consequences for future pregnancies are explained later on.

\section{Overview of the significance of vaginal delivery and planned caesarean section}

\begin{tabular}{|c|c|c|}
\hline & Vaginal delivery & Planned caesarean section \\
\hline $\begin{array}{l}\text { What does this } \\
\text { mean for the } \\
\text { mother? }\end{array}$ & $\begin{array}{l}\text { More involvement in the } \\
\text { baby's birth } \\
\text { Experiencing a 'normal birth': } \\
\text { baby on the breast, quickly } \\
\text { commencing possible } \\
\text { breastfeeding, more control } \\
\text { over the first hours after birth. } \\
\text { Contraction pains } \\
\text { Possibility of vaginal tearing } \\
\text { and stitches } \\
\text { Risk of (emergency) caesarean } \\
\text { section }\end{array}$ & $\begin{array}{l}\text { More control over how and } \\
\text { when the delivery takes place } \\
\text { (unless the delivery begins } \\
\text { early anyway) } \\
\text { Initial period after the birth } \\
\text { often spent in the operating } \\
\text { theatre/recovery room } \\
\text { without the baby } \\
\text { Pain after the operation } \\
\text { Risks accompanying every } \\
\text { operation: higher risk of } \\
\text { thrombosis, infection, } \\
\text { bleeding } \\
\text { Chance that a general } \\
\text { anaesthetic must be applied } \\
\text { instead of an epidural }\end{array}$ \\
\hline $\begin{array}{l}\text { What does this } \\
\text { mean for the } \\
\text { baby? }\end{array}$ & $\begin{array}{l}\text { A natural birth better prepares } \\
\text { the baby for breathing } \\
\text { independently }\end{array}$ & $\begin{array}{l}\text { The overall chance of } \\
\text { complications is a little less } \\
\text { with a planned caesarean } \\
\text { section }\end{array}$ \\
\hline $\begin{array}{l}\text { What does this } \\
\text { mean for the post- } \\
\text { natal period? }\end{array}$ & $\begin{array}{l}\text { Quick return to home } \\
\text { 'Normal activities' can be } \\
\text { resumed after 2-3 days }\end{array}$ & $\begin{array}{l}\text { 3-4 days in hospital } \\
\text { 'Normal activities' can be } \\
\text { resumed after } 6 \text { weeks }\end{array}$ \\
\hline
\end{tabular}




\section{What are my chances of a successful vaginal delivery?}

The overall chance of complications is less with women who deliver vaginally. An average of $70-75 \%$ of women who attempt a vaginal delivery succeed: a planned caesarean section is therefore not better for the group as a whole. However, if your chance of success is much smaller or much greater, this can play a part in your decision.

Mathematical model: your personal chance of delivering vaginally (from the $32 \mathrm{nd}$ week of pregnancy)

From the 32nd week of pregnancy, we can calculate your chances of success on the basis of your medical history and current situation. Your gynaecologist can calculate this for you during the appointment using a mathematical model.

\section{If you have opted for a vaginal delivery, your personal chance of an actual vaginal delivery} is

\section{Figuur 1. Kans op een vaginale bevalling}

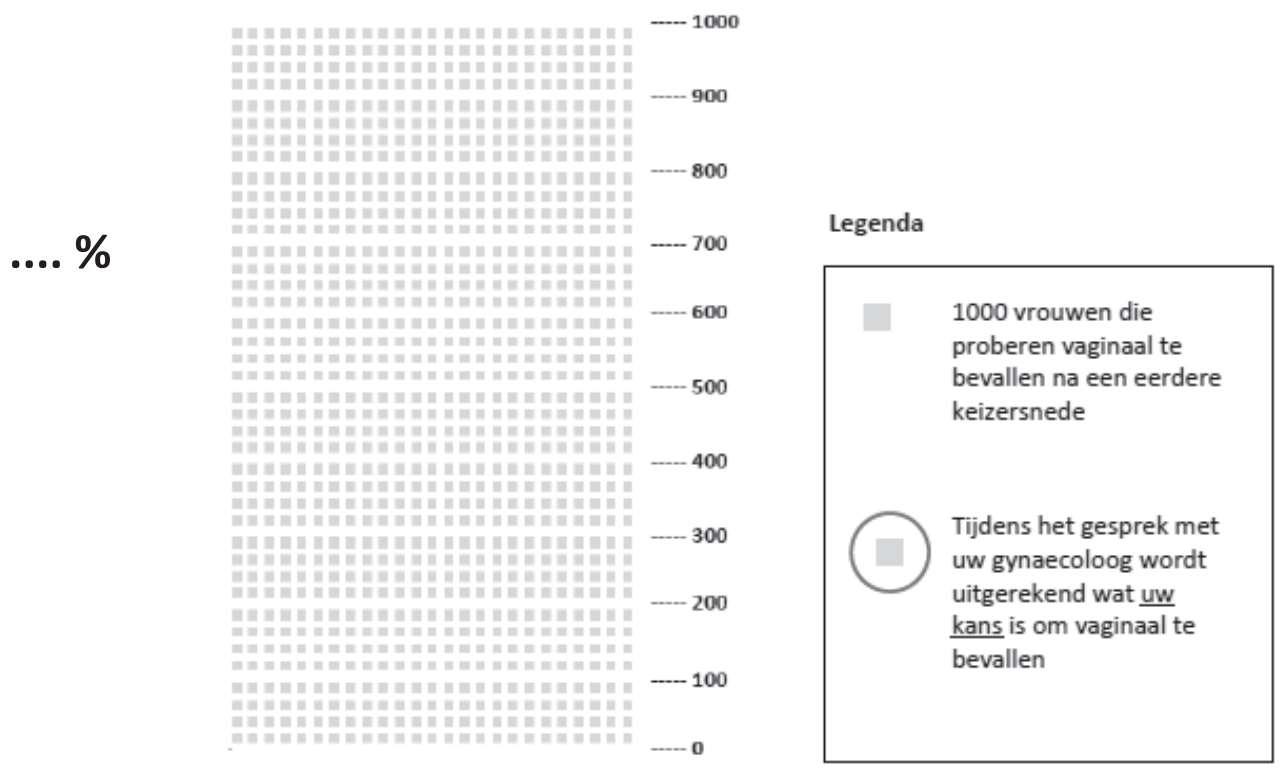

When the delivery begins before the calculated date, the chances that you will deliver vaginally are possibly greater. However, if the delivery must be induced, you have a slightly smaller chance of delivering vaginally and the calculation aid must be completed anew.

Figure 1. Chances of a vaginal delivery

Legend

1,000 women who try to deliver vaginally after a previous caesarean section

Your chances of delivering vaginally will be calculated during the discussion with your gynaecologist. 


\section{What are the chances of serious complications for me or the baby?}

The complication that people fear most is a 'uterine rupture', the tearing open of the old scar on the uterus. This can have serious consequences for mother and baby, but the risk of lasting consequences is small with a rapid intervention. The chance of this varies around the world from 2 to 15 per 1,000 women who commence a vaginal delivery and is probably dependant on risk factors, such as the use of induction medication. The numbers below are average figures.

\section{Risk of uterine rupture per 1,000 deliveries}

\begin{tabular}{|l|l|c|}
\hline & Vaginal delivery & Planned caesarean section \\
\hline Uterine rupture & $8(2$ to 15$)$ per 1,000 & 0.3 per 1,000 \\
\hline
\end{tabular}

Figuur 2. Risico op uterusruptuur per 1000 bevallingen
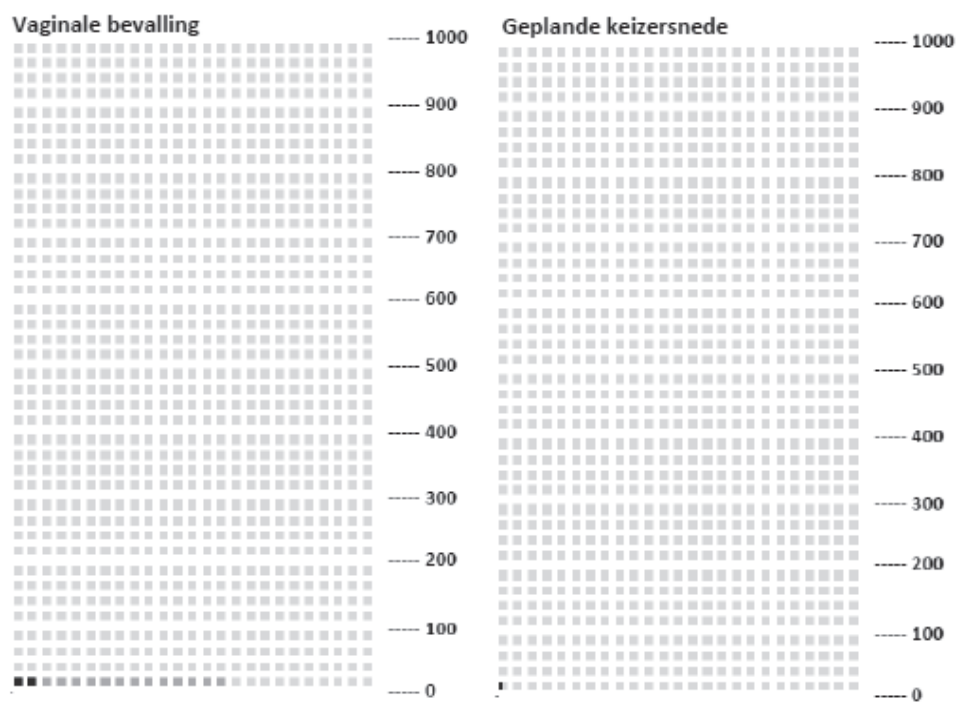

Legenda

\begin{tabular}{|c|}
\hline $\begin{array}{l}\text { Aantal vrouwen dat } \\
\text { geen uterusruptuur } \\
\text { krijgt van } 1000 \text { vrouwen }\end{array}$ \\
\hline $\begin{array}{l}\text { (Minimum) aantal vrouwen } \\
\text { dat wel een uterusruptuur } \\
\text { krijgt van } 1000 \text { vrouwen }\end{array}$ \\
\hline $\begin{array}{l}\text { Maximum aantal vrouwen } \\
\text { dat wel een uterusruptuur } \\
\text { krijgt van } 1000 \text { vrouwen }\end{array}$ \\
\hline
\end{tabular}

Figure 2. Risk of uterine rupture per 1,000 deliveries

Vaginal delivery / Planned delivery / Legend

Number of women per 1,000 without uterine rupture

(Minimum) number of women per 1,000 with uterine rupture

Maximum number of women per 1,000 with uterine rupture 
The chance of serious complications arising as a consequence of uterine rupture or other possible problems is very small and is described below.

\section{Risk of mortality per 1,000 deliveries}

\begin{tabular}{|l|c|c|}
\hline & Vaginal delivery & Planned caesarean section \\
\hline Mother mortality & 0.04 per 1,000 & 0.13 per 1,000 \\
\hline Child mortality & 1.30 per 1,000 & 0.50 per 1,000 \\
\hline
\end{tabular}

\section{Risk of serious injury to the baby}

The milder complications for a planned caesarean section are similar to those of a vaginal delivery and occur in less than $5 \%$ of cases. Breathing problems are seen more often with planned caesarean sections, but with vaginal deliveries there are a larger number of problems when delivering the baby's shoulders. These differences are difficult to weigh up against each other and there is no difference in neurological damage or long-term outcomes. There is therefore no difference in the chance of serious lasting injury for the baby.

\section{Risk of serious injury to the mother}

The overall chances of serious complications with the mother (uterine rupture, hysterectomy or operation damage) are displayed in the table below. There is a difference in the chance of complications between women who actually deliver vaginally and women who eventually have to deliver by unplanned caesarean section, whether it concerns an emergency caesarean section or not.

\section{Risks of serious complications for the mother per 1,000 deliveries}

\begin{tabular}{|l|l|l|}
\hline & Vaginal delivery & Planned caesarean section \\
\hline $\begin{array}{l}\text { Serious injury to the } \\
\text { mother }\end{array}$ & $\begin{array}{l}\text { Actual vaginal delivery: } \\
2 \text { per } 1,000\end{array}$ & 8 per 1,000 \\
\cline { 2 - 3 } & $\begin{array}{l}\text { Unplanned caesarean section: } \\
38 \text { per } 1,000\end{array}$ & \\
\hline
\end{tabular}




\section{Figuur 3. Risico's ernstige schade moeder per 1000 bevallingen}

\section{Gelukte vaginale bevalling}

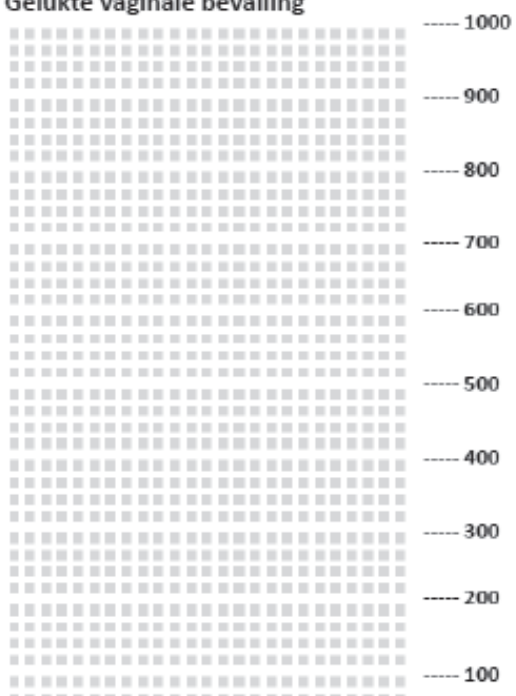

\section{(Spoed)keizersnede}

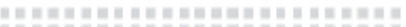
보ำ

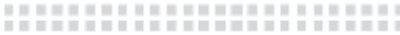
||

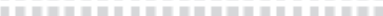

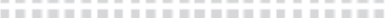

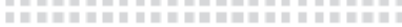
|| ำ

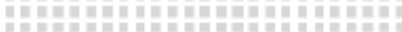

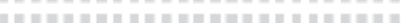

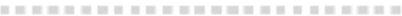

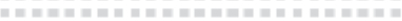

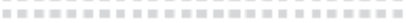
|

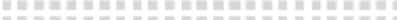

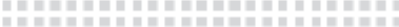
n|m

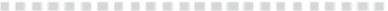

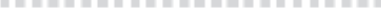
แ |

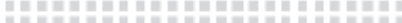

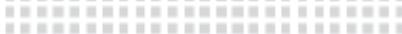

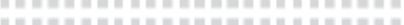
10

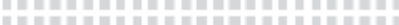

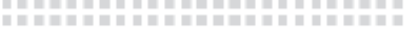
|| $\mid$ || ||

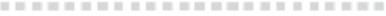

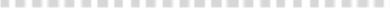

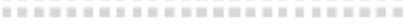

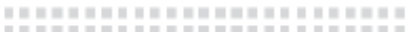

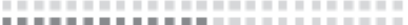

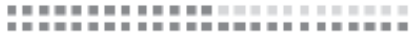

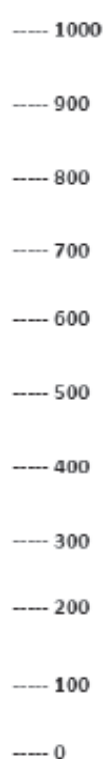

\section{Geplande keizersnede}

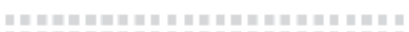
을

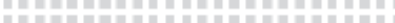

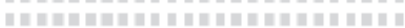

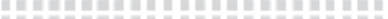

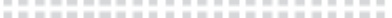

-

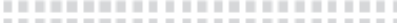
The

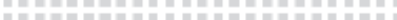

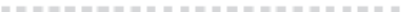

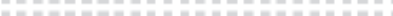

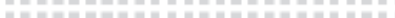

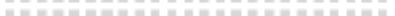

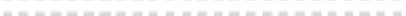

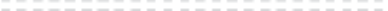

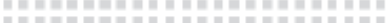

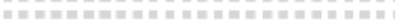

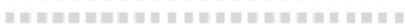

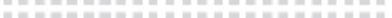

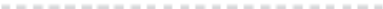

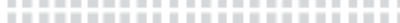

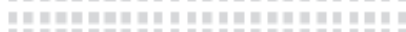

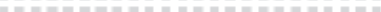

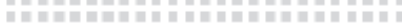

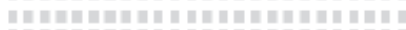
볼

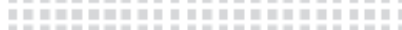

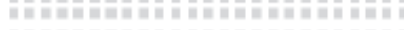

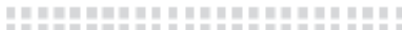

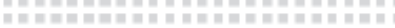

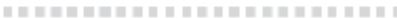

$-1000$

$-900$

$-800$ $-700$ $-600$ 500 $-100$ $-300$

Legenda

\begin{tabular}{|l|}
\hline Aantal vrouwen van \\
1000 vrouwen dat geen \\
ernstige complicatie \\
krijgt \\
Aantal vrouwen van \\
1000 vrouwen dat \\
vaginaal bevalt en wel \\
een ernstige \\
complicatie krijgt \\
Aantal vrouwen van \\
1000 vrouwen dat een \\
(spoed)keizersnede \\
krijgt en wel een \\
ernstige complicatie \\
krijgt \\
Aantal vrouwen van \\
1000 vrouwen dat een \\
geplande keizersnede \\
krijgt en wel een \\
ernstige complicatie \\
krijgt
\end{tabular}

Figure 3. Risk of serious damage to the mother per 1,000 deliveries Successful vaginal delivery / Planned caesarean section / (Emergency) caesarean section / Legend Number of women per 1,000 without serious complications

Number of women per 1,000 with serious complications from vaginal delivery Number of women per 1,000 with serious complications from a(n) (emergency) caesarean section Number of women per 1,000 with serious complications from a planned caesarean section 


\section{Will my decision influence any future pregnancies?}

After 2 caesarean sections, in most cases the next delivery will once again be a caesarean section. The chances of complications with each 'additional' caesarean section rise for the following pregnancy. The most important risks for a following pregnancy are: greater chance of a placenta previa (placenta fully or partially blocks the cervix) and an ingrown placenta, where the placenta grows into the uterine wall. There is also a greater risk of blood loss, intensive care admission and the need for a hysterectomy. Naturally these problems can be related and the total number is an estimate of the number of women who will develop 1 or more problems. Less serious operation risks such as infections also occur more often after multiple caesarean sections.

The chances of serious complications occurring with future pregnancies per

\section{1,000 deliveries}

\begin{tabular}{|l|l|l|}
\hline & $\begin{array}{l}\text { With the } 3 \text { rd } \\
\text { caesarean section }\end{array}$ & $\begin{array}{l}\text { With the 4th caesarean } \\
\text { section }\end{array}$ \\
\hline Placenta previa & 18 per 1,000 & 30 per 1,000 \\
21 per 1,000 \\
Ingrown placenta & 6 per 1,000 & 24 per 1,000 \\
\hline $\begin{array}{l}\text { IC admission of mother } \\
\text { Blood loss with transfusion of }>4 \text { blood } 1,000\end{array}$ & 8 per 1,000 & 16 per 1,000 \\
bags & 6 per 1,000 & 16 per 1,000 \\
\hline $\begin{array}{l}\text { Damage to urinary tract or bowel } \\
\text { Estimate of overall chance of } 1 \text { or } \\
\text { more complications }\end{array}$ & 40 per 1,000 & 80 per 1,000 \\
\hline
\end{tabular}




\section{Figuur 5. Kans op optreden van het totaal aantal complicaties bij toekomstige zwangerschappen per} 1000 bevallingen

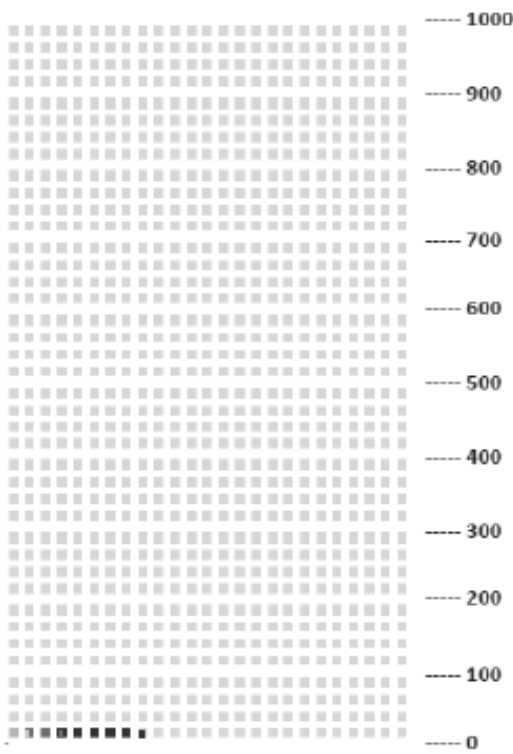

Legenda

Van 1000 vrouwen het aantal vrouwen dat geen van de genoemde complicaties krijgt in een toekomstige zwangerschap

Van 1000 vrouwen het aantal vrouwen dat 1 of meer van de genoemde complicaties krijgt na 1 keizersnede (uw huidige zwangerschap)

Van 1000 vrouwen het aantal vrouwen extra dat 1 of meer van de genoemde complicaties krijgt na 2 keizersnedes van 1000 vrouwen

Van 1000 vrouwen het aantal vrouwen extra dat 1 of meer van de genoemde complicaties krijgt na 3 keizersnedes

Figure 5 Chance of occurrence of total number of complications for future pregnancies per 1,000 deliveries / Legend Number of women per 1,000 without any of the stated complications in future pregnancy Number of women per 1,000 with one or more of the stated complications after 1 caesarean section (your current pregnancy)

Number of extra women per 1,000 with one or more of the stated complications after 2 caesarean sections Number of extra women per 1,000 with one or more of the stated complications after 3 caesarean sections

\section{Summary}

No serious complications occur with mother or baby in more than $95 \%$ of all deliveries, no matter how the delivery began - planned caesarean section or vaginal delivery.

The chances of complications for the mother are related to the eventual method of delivery. For women who do deliver vaginally, the chances of serious complications are the lowest ( 2 per 1,000$)$, followed by the group with a planned caesarean section $(8$ per 1,000$)$. The group that starts a vaginal delivering but eventually undergoes a caesarean section has the greatest risk of complications (38 per 1,000). Of these, however, less than $5 \%$ of cases could be said to be an emergency caesarean section.

The chance of complications with future pregnancies increases with each additional caesarean section. 
Step 4 My considerations

Below you can indicate the important elements for you to reach a decision.

\begin{tabular}{|c|c|c|c|c|}
\hline $\begin{array}{l}\text { What are important factors for you (and } \\
\text { your partner)? }\end{array}$ & $\underset{\substack{3 \\
\frac{0}{0}}}{\frac{\overline{0}}{2}} \frac{1}{2}$ & $\begin{array}{l}\overline{3} \\
\frac{0}{0} \\
\frac{0}{7} \\
\frac{1}{2} \\
\frac{1}{2}\end{array}$ & 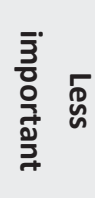 & 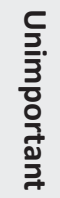 \\
\hline When delivering vaginally & & & & \\
\hline 1. I feel more involved with the baby's birth & & & & \\
\hline 2. I experience a normal delivery & & & & \\
\hline 3. It takes place in the natural way & & & & \\
\hline 4. I experience contraction pains & & & & \\
\hline 5. I have less control over the process & & & & \\
\hline 6. I could tear/need to be cut & & & & \\
\hline $\begin{array}{l}\text { 7. There is a risk of needing an emergency } \\
\text { caesarean section }\end{array}$ & & & & \\
\hline 8. My personal chance of a vaginal delivery & & & & \\
\hline When delivering by caesarean section & & & & \\
\hline $\begin{array}{l}\text { 9. I have more control over how and when the } \\
\text { delivery takes place }\end{array}$ & & & & \\
\hline 10. I will definitely need to undergo an & & & & \\
\hline $\begin{array}{l}\text { operation } \\
\text { 11. I will experience more pain after the } \\
\text { operation }\end{array}$ & & & & \\
\hline $\begin{array}{l}\text { 12. There is an increased chance of } \\
\text { complications, such as thrombosis, infection } \\
\text { and bleeding }\end{array}$ & & & & \\
\hline
\end{tabular}




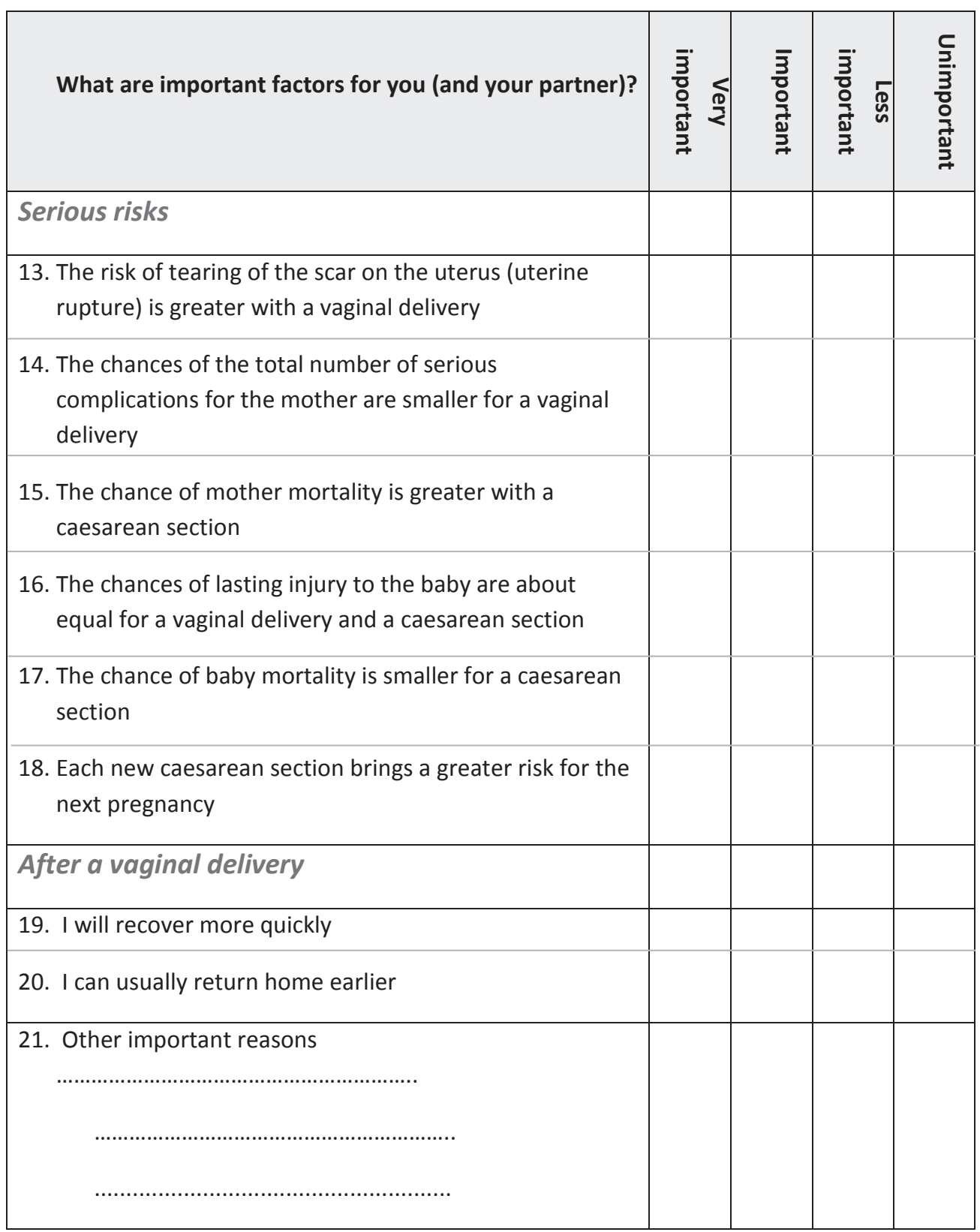




\section{Step 5 Wishes}

There is a possibility that your choice for a vaginal delivery depends on a number of conditions/wishes (e.g. proper pain relief, quick procedure). Please feel free to write these wishes/conditions down below so that they can be added to your file:

\section{Step 6 The provisional choice}

$\square$ A vaginal delivery

A planned caesarean section

\section{Step 7 What next?}

You have made a provisional choice together with your doctor. You have the option to, after thinking it through some more, change your decision. There is also the possibility that the situation changes: there can be a reason for labour to be induced, the baby can come too early or the baby could have become very large. This can change your chances of success and, with that, your choice as well.

Should you have chosen for a planned caesarean section, it is also possible that the delivery starts earlier than planned. Because of this, the chances of success for a vaginal delivery could improve, in which case you may well prefer to have a normal delivery. situation change. 


\section{Induced labour after a caesarean section}

This part of the decision aid is for women who have opted for a vaginal delivery after a previous caesarean section and for whom there is now reason to induce labour.

\section{Inducing labour}

If a delivery does not start spontaneously, or if the delivery must take place sooner for medical reasons, then labour can be induced. With an induction, doctors try to get your labour to start using a 'balloon' or medication. The table below states that labour induction has consequences for your chances of actually delivering vaginally. Also, the chances of the uterus scar tearing (uterine rupture) are possibly a little greater when your labour is induced.

\section{Induction after a caesarean section}

\begin{tabular}{|l|l|}
\hline & $\begin{array}{l}\text { Induction of a vaginal delivery after a } \\
\text { previous caesarean section }\end{array}$ \\
\hline $\begin{array}{l}\text { How are the chances of you delivering } \\
\text { vaginally affected? }\end{array}$ & $\begin{array}{l}\text { With an induction after a previous caesarean } \\
\text { section, the chances of delivering vaginally } \\
\text { are possible a little smaller. For this reason, } \\
\text { your gynaecologist will calculate this for you } \\
\text { once again. }\end{array}$ \\
\hline $\begin{array}{l}\text { How are my chances of complications } \\
\text { affected with an induction? }\end{array}$ & $\begin{array}{l}\text { Your new chance is .......\% } \\
\text { difference in the chances of the uterus scar } \\
\text { tearing (uterine rupture). }\end{array}$ \\
\cline { 2 - 3 } & $\begin{array}{l}\text { Medication: this is } 15 \text { per } 1,000 \text { when using } \\
\text { prostaglandins (gel, tablets); about } 10 \text { per } \\
1,000 \text { when using a drip. }\end{array}$ \\
\hline
\end{tabular}


The decision aid was developed in the context of the Cesarean Section IMPLEmentation study (SIMPLE) as part of a ZonMW project, subsidy number 80-82315-97-10005.

\section{Project leaders}

Dr H.C.J. Scheepers, gynaecologist/perinatologist, Maastricht UMC+

Dr R.P.M.G. Hermens, IQ Healthcare Nijmegen

\section{Research physicians}

S. Melman, MSc, E.N.C. Schoorel, E. Vankan, Maastricht UMC+

\section{Project group members}

Prof J.G. Nijhuis, PhD, gynaecologist/perinatologist, Maastricht UMC+ Dr L.J.M. Smits, epidemiologist, Maastricht University Prof T. van der Weijden, PhD, Maastricht University Dr A. Kwee, gynaecologist/perinatologist, UMC Utrecht Dr S.M. van Kuijk, epidemiologist, Maastricht University Prof C.D. Dirksen, PhD, HTA expert, Maastricht UMC+

\section{Expert panel}

Dr R. Aardenburg, Orbis Medical Centre, Sittard

Dr K. de Boer, Rijnstate, Arnhem

Dr T.H.M. Hasaart, Catharina Hospital, Eindhoven

Ms M. Nieuwenhuijze, Academie Verloskunde [Obstetrics], Maastricht Prof J.G. Nijhuis, PhD, gynaecologist/perinatologist, Maastricht UMC+

Dr M.G. Pampus, OLVG Amsterdam

Prof J.J.M. van Roosmalen, PhD, LUMC, Leiden

Dr F.J.M.E. Roumen, Atrium Medisch Centrum Parkstad, Heerlen

Prof R. de Vries, PhD, Academie Verloskunde [Obstetrics], Maastricht

Dr M.G.A.J. Wouters, VU Medisch Centrum, Amsterdam

Prof B.W.J. Mol, PhD, AMC, Amsterdam

C This product is protected by copyright and may not be reproduced or distributed without permission. 


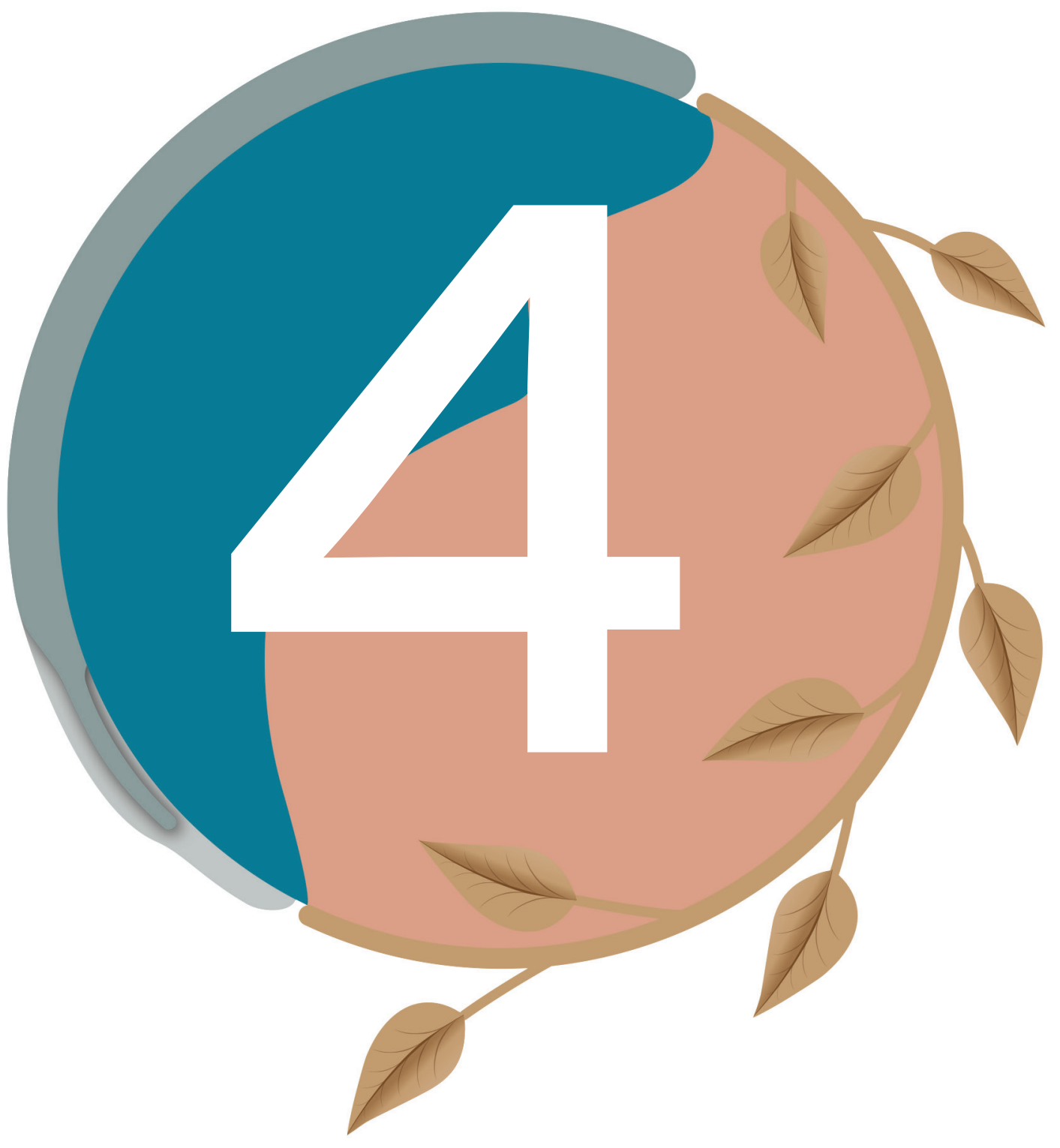


Chapter 4

\section{The effect of the use of a decision aid with individual risk estimation on the mode of delivery after a caesarean section: a prospective cohort study}

Vankan E, Schoorel E, van Kuijk S, Nijhuis J, Hermens R, Scheepers H;

SIMPLE study group

PloS one, 2019 Sep 26;14 


\section{Abstract}

\section{Objective}

After one previous caesarean section (CS), pregnant women can deliver by elective repeat CS or have a trial of labour which can end in a vaginal birth after caesarean (VBAC) or an unplanned CS. Despite guidelines describing women's rights to make an informed choice, trial of labour and VBAC rates vary greatly worldwide. Many women are inadequately informed due to caregivers' fear of an increase in CS rates in a high VBAC rate setting. We compared counselling with a decision aid (DA) including a prediction model on VBAC to care as usual. We hypothesize that counselling with the DA does not decrease VBAC rates. In addition, we aimed to study the effects on unplanned CS rate, patient involvement in decision-making and elective repeat CS rates.

\section{Methods}

We performed a prospective cohort study. From 2012 to 2014, 483 women in six hospitals, where the DA was used (intervention group), were compared with 441 women in six matched hospitals (control group). Women with one previous CS, pregnant of a singleton in cephalic presentation, delivering after 37 weeks 0 days were eligible for inclusion.

\section{Results}

There was no significant difference in VBAC rates between the intervention (45\%) and control group (46\%) (adjusted odds ratio 0,92 (95\% Confidence interval 0.69-1.23)). In the intervention group more women (42\%) chose an elective repeat CS compared to the control group (31\%) (adjusted odds ratio 1.6 (95\% Confidence interval 1.18-2.17)). Of women choosing trial of labour, in the intervention group $77 \%$ delivered vaginally compared to $67 \%$ in the control group, resulting in an unplanned CS adjusted odds ratio of $0,57(0.40-0.82)$ in the intervention group. In the intervention group, more women reported to be involved in decision-making ( $98 \%$ vs. $68 \%, P<0.001$ ).

\section{Conclusions}

Implementing a decision aid with a prediction model for risk selection suggests unchanged VBAC rates, but 40\% reduction in unplanned CS rates, increase in elective repeat CS and improved patient involvement in decision-making. 


\section{Introduction}

After one previous caesarean section (CS), pregnant women can deliver by elective repeat caesarean section (ERCS) or have a trial of labor (TOL) which can end in a vaginal birth after caesarean (VBAC) or an unplanned CS. Despite guidelines describing women's rights to make an informed choice and that for most women vaginal birth is safe [1-3], TOL and VBAC rates vary greatly worldwide [4]. In the United States (US), the VBAC rate is around 8.3\% [5]. In 2015, 1.3 million women in the US underwent a CS (32\%) [6], making it one of the most frequently performed operative interventions in women. In The Netherlands, VBAC rates are much higher (54\%) [7], but most women are inadequately informed about their choices due to caregivers' fear of an increase in CS rates [8]. Morbidity risks (both maternal and neonatal) are directly related to the individual probability of VBAC since morbidity is lowest in women with VBAC, but higher in women with unplanned than planned CS [9]. We developed a decision aid (DA) containing evidence based information including a prediction model [10, 11]. A better inventory of risks, benefits and chance of success might improve shared decision making and reduce unplanned CSs without bringing down the number of VBAC.

We aimed to evaluate the effect of counseling with a decision aid (DA) including a prediction model compared to regular counseling without the DA on the VBAC-rate. We hypothesize that counseling with the DA does not decrease VBAC rates (i.e. noninferiority with respect to VBAC rate). In addition, we aimed to study the effects on unplanned CS rate, patient involvement in decision-making, ERCS rate, guideline adherence and maternal and neonatal complications. 


\section{Materials and methods}

\section{Study design \& setting}

We performed a prospective cohort non-inferiority study: we hypothesised that counseling with the DA does not decrease VBAC rates. In a preliminary study in 2010 [12], VBAC and TOL rates in 17 hospitals in the Netherlands were studied as part of the SIMPLE I study. For this current study (SIMPLE II), twelve of these hospitals were selected based on type of hospital (university, teaching and non-teaching hospitals) and their 2010 VBAC rates (<percentile (p) 20, p20-80 and >p80) and divided into six matched pairs based on these criteria. The groups had a comparable VBAC rate in the pre-measurement (46 vs 53\%, non-significant). In the period between September 2012 and September 2014, we applied our DA in six of the hospitals (intervention hospitals) in one region, and compared VBAC rates and the secondary outcomes with the six matched hospitals providing counseling without the DA (control hospitals) (S1 File).

This design was chosen based on different facts. There is close collaboration between hospitals and midwifery practices in a small country as the Netherlands. Midwifery practices may work with several hospitals in one region. In this study setting referring midwives would not have to deal with two policies, with chance of bias. Besides, caregivers like residents who work in different settings in one region during their specialization were not biased by knowledge of the use of the DA when they switch to another hospital.

The study was a consecutive study of the previously reported SIMPLE study [8]. The study was initially designed as a controlled before and after study with an intervention trial incorporated in the second part. When reporting the results, this created an overcomplicated method section with no added value to the results. In this final design, data from the before measurement were used to select two comparative groups of hospitals (S1 Table). In this setting the prospective intervention trial was performed, improving clarity of the study.

\section{Study population}

All women with a singleton pregnancy and a foetus in cephalic position, delivering after 37 weeks after one previous CS, without a contra-indication for a TOL, were eligible for inclusion. The DA was developed as a tool to improve guideline adherence. Therefore, the Medical Ethical Committee of the MUMC+ agreed that no individual informed consent was needed for receiving the DA (the DA was assigned at hospital level). The DA was administered to all eligible women in only the intervention hospitals. Informed consent was only needed and obtained from the patients (with command of the Dutch language), who were willing to complete the questionnaire. 


\section{Intervention}

We developed a DA for mode of delivery after previous CS including a prediction model for predicting the individual probability of a VBAC. The content was based on literature search, expert's opinion and the contemporary international guidelines on delivery after previous CS [11]. Seven steps essential for decision-making in mode of delivery were included: preferences for mode of delivery before reading the DA (1), previous birth experiences (2), risks and benefits of TOL and ERCS (including the prediction model) (3), a worksheet to weigh out the options (4), a birth plan where women can write down their preferences (5), preliminary choice (6) and follow-up to reevaluate the decision (7). The DA was developed according to the IPDAS criteria and pilot tested in 25 women.

A woman's individual probability on a VBAC was calculated with a previously developed prediction model [10]. This model was developed for a West-European population and includes indication for previous CS, body mass index (BMI), need for labor induction, ethnicity, estimated fetal weight in the current pregnancy and a previous vaginal delivery. Our database was too small to determine a cut-off level in individual probability on VBAC and in temporary literature there is no evidence for a specific cut-off level. For this reason, we did not present a cut-off level, giving women a possibility to weigh their own probability. Women in the intervention hospitals received the DA before 36 weeks of pregnancy were able to read and discuss it with relevant others before discussing the mode of delivery with their obstetrical caregiver. During consultation around 36 weeks the DA was used as guidance of the counseling for mode of delivery and shared decision making and the prediction model was filled in. The woman's individual probability on a VBAC was then showed in a percentage. At this point a shared decision was made on the mode of delivery. During this consultation women were asked for informed consent for completing the questionnaire send by email. The counseling was repeated if the circumstances changed (for example when labor induction was needed). In each intervention hospital, a one-hour training for healthcare professionals was organized to discuss the content of the DA and to instruct how to use the DA in daily practice.

In the control hospitals, patients received according to the contemporary guideline oral and/or written information on mode of delivery after CS as usual from their obstetrician or midwife during regular consultations in their pregnancy. According to the contemporary Dutch guideline women should be informed about the chance of a VBAC, the risk of a uterine rupture, the increased risk of a uterine rupture in use of oxytocin or prostaglandins, the risks and advantages of an ERCS, the implications for a possible next pregnancy and the policy in case of spontaneous labor. The discussion on mode of delivery also took place around 36 weeks during consultation. The DA and the prediction model were not used in the control group. 


\section{Outcome measures}

The primary outcome was the VBAC-rate. Secondary outcomes were unplanned CS rate, patient involvement in decision-making, ERCS rate, guideline adherence for counseling and maternal and neonatal complications. Patient involvement was defined as a positive answer to the question if a woman felt involved in the decision making regarding the choice of mode of delivery. This question was part of a validated questionnaire, used for other studies as well [13].

Guideline adherence was defined as mentioning in the patient chart discussing the following items: risk of uterine rupture, the increased risk of uterine rupture when using oxytocin or prostaglandins, the chance of VBAC, and risk of perinatal mortality. Maternal complications included more than 4 packed cells, uterine rupture, hysterectomy, operational injury, thrombosis, maternal death and admission to the intensive care unit. Neonatal complications included neonatal death, neonatal asphyxia, plexus lesion of fracture and admission to the neonatal intensive care.

\section{Sample size}

We hypothesised an equal VBAC rate between the intervention and control group and considered a decrease in VBAC rate of over $10 \%$ in the intervention group undesirable. Therefore, a non-inferiority limit of $10 \%$ was chosen. Consequently, a VBAC rate of more than $10 \%$ reduction in the intervention group compared to the control group would be seen as 'inferior 'care. In 2010 the SIMPLE study showed a national VBAC rate of 49\% [12]. The necessary sample size for showing noninferiority, with an alpha of 0.05, a beta of 0.20, and an intra-cluster correlation coefficient (ICC) of 0.2, was 400 per study-arm.

Each hospital was asked to prospectively include 80 consecutive eligible women. The participating hospitals were requested to administer questionnaires to a convenience sample of 30 of the 80 eligible patients during the study-period. This sample size was based on a needed number for measuring decisional conflict also measured with this validated questionnaire [13] also used for other studies. The Ottawa Health Decision Centre indicates that an effect size of 0.3-0.4 is meaningful [14]. We chose an alpha of 0.05 , a beta of 0.20 and a standard deviation of 17.5 [15]. Therefore, for detecting an effect size of at least 0.3, a difference between DC scores of 5.25 between the intervention group and the control group was needed. We estimated the ICC to be 0.2. The estimated sample size, corrected for cluster variation, was 200 per study arm. 


\section{Data collection}

Data on VBAC, unplanned CS and ERCS were collected from the medical records and national perinatal registry by trained staff using case report forms. A validated questionnaire was used to ask among other things, whether patients felt involved in the decision making regarding the choice of mode of delivery [13]. The questionnaire was handed out to the patients online at 37 weeks of pregnancy after informed consent. Patients were instructed to fill in the questionnaire after discussing and having decided upon mode of delivery with their obstetric caregiver. The variables of guideline adherence (risk of uterine rupture, the increased risk of uterine rupture when using oxytocin or prostaglandins, the chance of VBAC, and risk of perinatal mortality) were measured according to their frequency of documentation in the medical records. Data on maternal complications(more than 4 packed cells, uterine rupture, hysterectomy, operational injury, thrombosis, maternal death and admission to the intensive care unit) and neonatal complications (neonatal death, neonatal asphyxia, plexus lesion of fracture and admission to the neonatal intensive care) were extracted from medical records and the national perinatal registration. Information on actual use of the DA, demographic factors, obstetric history, and current pregnancy (co-variables) to check if the intervention group and control group were comparable, was extracted from medical records and the national perinatal registry.

\section{Statistical analyses}

Data analysis was carried out using SPSS 21. All consecutive eligible women were included in the statistical analysis, irrespective of their actual exposure to the DA. Only the women, who gave informed consent for the questionnaire, received the questionnaire. The data were entered in the study database by study staff. In case of inconsistencies, data were checked with the hospital concerned. Missing covariable data were imputed using stochastic regression imputation, since complete case analysis may decrease statistical power and induce bias if data are not 'missing' completely at random.

In order to study the effects of the DA, data analysis was performed according to intention-to-treat and per-protocol principle (women actually receiving the DA). Noninferiority was analyzed by converting the non-inferiority limit of 10\% (in relative risk) to a limit in odds ratio (OR) on VBAC in the intervention group compared to the control group. The OR's for VBAC were calculated by multivariable regression analysis, correcting for the variables of the prediction model and age. To check for non-inferiority, the $95 \%$ confidence interval $(\mathrm{Cl})$ of the OR was then assessed with the non-inferiority limit. If the $95 \%$ Cl limits were exceeding the non-inferiority limit, noninferiority cannot be proven. The same procedure for calculating OR was followed for 
the unplanned CS rate. Differences in patient involvement and guideline adherence between women in the intervention and control group were tested using chi-square. The relative risks estimates for complications were calculated using cross-tabs.

\section{Details of ethical approval}

Ethical approval for this study was obtained from the Medical Ethical Committee of Maastricht University Medical Centre+ in The Netherlands (MEC number 12-4-091) (2507-2012). The study started in September 2012. Local approval was received from the boards of directors of local hospitals. Written informed consent was obtained from the patients willing to complete the questionnaire. The DA was developed as a tool to improve guideline adherence. Therefore the Medical Ethical Committee of the MUMC+ agreed that no individual informed consent was considered needed for this part of the study.

\section{Trial registration}

This study is registered at ClinicalTrials.gov: Current Dutch Practice on Caesarean Sections: Identification of Barriers and Facilitators for Optimal Care (SIMPLE), NCT01261676, https://clinicaltrials.gov//show/NCT01261676?term=cesarean\&rank=18 


\section{Results}

\section{Baseline characteristics}

Table 1 shows that baseline characteristics of the women in the intervention- and control-group were mostly comparable. In the intervention group women were a bit younger and had a shorter pregnancy, fewer women had a previous CS due to failure to progress and more women had a previous vaginal birth, however this difference was not significant.

\section{Main outcome}

We analyzed 924 women, 483 in the intervention group and 441 in the control group, respectively (fig. 1). All consecutive eligible women were included in each hospital, except for one control hospital due to bankruptcy (45 women included). No women were excluded. There was no difference in VBAC rates between the intervention and control group (45 vs. 46\%). The crude odds-ratio (OR) for VBAC for the intervention group compared to the control group, was 0,96 (95\% Cl 0,74-1,24). When correcting for differences in predictors of the prediction model in both groups, the adjusted OR was 0,92 (95\% Cl 0.69-1,23) (table 2). We also corrected for other possible predictors of VBAC: pre-eclampsia or the syndrome of hemolysis, elevated liver enzymes, and low platelet count (HELLP), hypertension and diabetes in the current pregnancy and maternal age based on previous studies [10], with unchanged outcome.

To test non-inferiority for VBAC, we used a non-inferiority limit of 10\% (RR 0.9 in case of a decrease in VBAC) which was converted into a limit in OR. Based on a prevalence of $46 \%$ of VBAC in the control group, the non-inferiority limit for the OR was 0.83 . The 95\% Cl of both the crude OR (0.96 (95\% Cl 0.74-1.24)) and the adjusted OR $(0,92$ $(95 \%$ Cl 0.69-1,23)) for VBAC crossed the non-inferiority limit in the intention to treat analysis. Therefore, even though the point estimate suggests that the use of the DA did not decrease VBAC beyond the non-inferiority limit, the results are not conclusive because of the wide confidence intervals. This occurred in the per-protocol analysis as well, where the crude OR was 1.1 (95\% Cl 0.81-1.49). In the intervention-group 269/483 (56\%) of the women received the DA. In the per-protocol analysis the VBAC rates were comparable as well (48\% vs. 46\%). The predicted chance of succeeding in VBAC was comparable in women who received the DA and who did not receive the DA in the intervention group $(p=0,95)$. 
Table 1. Baseline characteristics

\section{Intervention group $(\mathrm{N}=483)$}

N/Mean

$\% /$ range/SD

\begin{tabular}{|c|c|c|}
\hline $\begin{array}{l}\text { Demographic } \\
\text { factors }\end{array}$ & & \\
\hline Caucasian, (\%) & 395 & $82,2 \%$ \\
\hline Maternal age (years) & 33,33 & $\pm 4,35$ \\
\hline \multicolumn{3}{|l|}{$\operatorname{BMI}\left(\mathrm{kg} / \mathrm{m}^{2}\right)$} \\
\hline$<20$ & 44 & $10,6 \%$ \\
\hline $20-24,9$ & 165 & $39,7 \%$ \\
\hline $25-34,9$ & 174 & $41 \%$ \\
\hline$>35$ & 33 & $7,9 \%$ \\
\hline \multicolumn{3}{|l|}{ Obstetric history } \\
\hline Parity & 1,32 & 0,77 \\
\hline Indication previous CS failure to progress & 192 & $44,1 \%$ \\
\hline Previous vaginal birth & 91 & $19,0 \%$ \\
\hline \multicolumn{3}{|l|}{ Current pregnancy } \\
\hline Gestational age (in days) & 276,20 & 8,09 \\
\hline Estimated fetal weight from GA 32 weeks p $\geq 90$ & 27 & $6,4 \%$ \\
\hline Induction of labor & 90 & $21,5 \%$ \\
\hline
\end{tabular}

SD: standard deviation, chis: chi-square, BMI: body mass index, MW: Mann-Whitney-U test, CS: caesarean section, GA: gestational age, p: percentile, * missing data >10\%

Table 2. Mode of delivery outcome

\begin{tabular}{lll}
\hline & Intention to treat \\
\hline Mode of delivery & Intervention & Control \\
& $(\mathrm{N}=483)(\%)$ & $(\mathrm{N}=441)(\%)$
\end{tabular}

\begin{tabular}{lll}
\hline Elective repeat caesarean delivery & $201(41,6)$ & $137(31,1)$ \\
Spontaneous delivery & $182(37,7)$ & $167(37,9)$ \\
Instrumental delivery & $35(7,2)$ & $36(8,2)$ \\
Unplanned caesarean section & $65(13,5)$ & $101(22,9)$ \\
Intended vaginal birth (trial of labor) & $282(58,4)(282 / 483)$ & $304(68,9)(304 / 441)$ \\
Vaginal birth of those with a trial of labor & $217(76,9)(217 / 282)$ & $203(66,8)(203 / 304)$ \\
\hline Total VBAC rate & 217 & $203(46,0)(203 / 441)$ \\
\hline
\end{tabular}

OR: odds ratio, Cl: confidence interval, VBAC: vaginal birth after caesarean 


\section{Control group $(\mathrm{N}=441)$}

p-value/test

Missing

N/Mean

(\%/range/SD

Missing

$\begin{array}{lllll}3 & 343 & 78,3 \% & 3 & 0,14 / \text { chis } \\ 6 & 33,9 & \pm 4,53 & 24 & 0,06 / \text { t-test } \\ 67 & & & 94 & *\end{array}$

$\begin{array}{lll}32 & 9,2 \% & 0,55 / \text { chis } \\ 142 & 40,9 \% & 0,77 / \text { chis } \\ 149 & 42,9 \% & 0,90 / \text { chis } \\ 24 & 6,9 \% & 0,68 / \text { chis }\end{array}$

$2 \quad 1,29$

0,68

0,83/ MW

$48 \quad 201$

$47,1 \%$

3

$0,41 /$ chis

5

73

$16,7 \%$

3

$0,39 /$ chis

$\begin{array}{ll} & 277,23 \\ 59 & 33 \\ 65 & 94\end{array}$

7,83

0,044/MW

$7,6 \%$

$25,4 \%$

6

$0,51 /$ chis

0,21/ chis*

Per-protocol DA vs. control group

\begin{tabular}{|c|c|c|c|c|}
\hline $\begin{array}{l}\text { Crude OR } \\
(95 \% \mathrm{CI})\end{array}$ & $\begin{array}{l}\text { Adjusted OR } \\
(95 \% \mathrm{CI}) \\
\text { (corrected for } \\
\text { risk factors) }\end{array}$ & $\begin{array}{l}\text { Intervention } \\
\mathrm{N}=269)(\%)\end{array}$ & $\begin{array}{l}\text { Crude OR } \\
(95 \% \mathrm{CI})\end{array}$ & $\begin{array}{l}\text { Adjusted OR } \\
(95 \% \mathrm{CI}) \\
\text { (corrected for } \\
\text { risk factors) }\end{array}$ \\
\hline $1,6(1,21-2,07)$ & $1,6(1,18-2,17)$ & $112(41,6)$ & $1,6(1,16-2,17)$ & $1,6(1,14-2,32)$ \\
\hline $0,99(0,76-1,30)$ & $0,95(0,71-1,28)$ & $108(40,1)$ & $1,1(0,81-1,50)$ & $1,1(0,76-1,51)$ \\
\hline $0,88(0,54-1,42$ & $0,91(0,57-1,48)$ & $22(8,2)$ & $1,0(0,58-1,74)$ & $1,0 \quad(0,58-1,79)$ \\
\hline $0,52(0,37-0,74)$ & $0,57 \quad(0,40-0,82)$ & $27(10,0)$ & $0,38(0,24-0,59)$ & $0,41(0,26-0,66)$ \\
\hline $0,63(0,48-0,83)$ & $0,63(0,46-0,85)$ & $157(58,4)$ & $0,63(0,46-0,87)$ & $0,62(0,43-0,88)$ \\
\hline $1,7(1,15-2,39)$ & $1,4(0,96-2,12)$ & $130(82,8)$ & $2,4(1,49-3,87)$ & $2,0(1,17-3,28)$ \\
\hline $0,96(0,74-1,24)$ & $0,92(0,69-1,23)$ & $130(48,3)$ & $1,1(0,81-1,49)$ & $1,1(0,77-1,50)$ \\
\hline
\end{tabular}




\section{C ONSORT}

TRANSPARENT REPORTING of TRIALS

\section{CONSORT 2010 Flow Diagram}

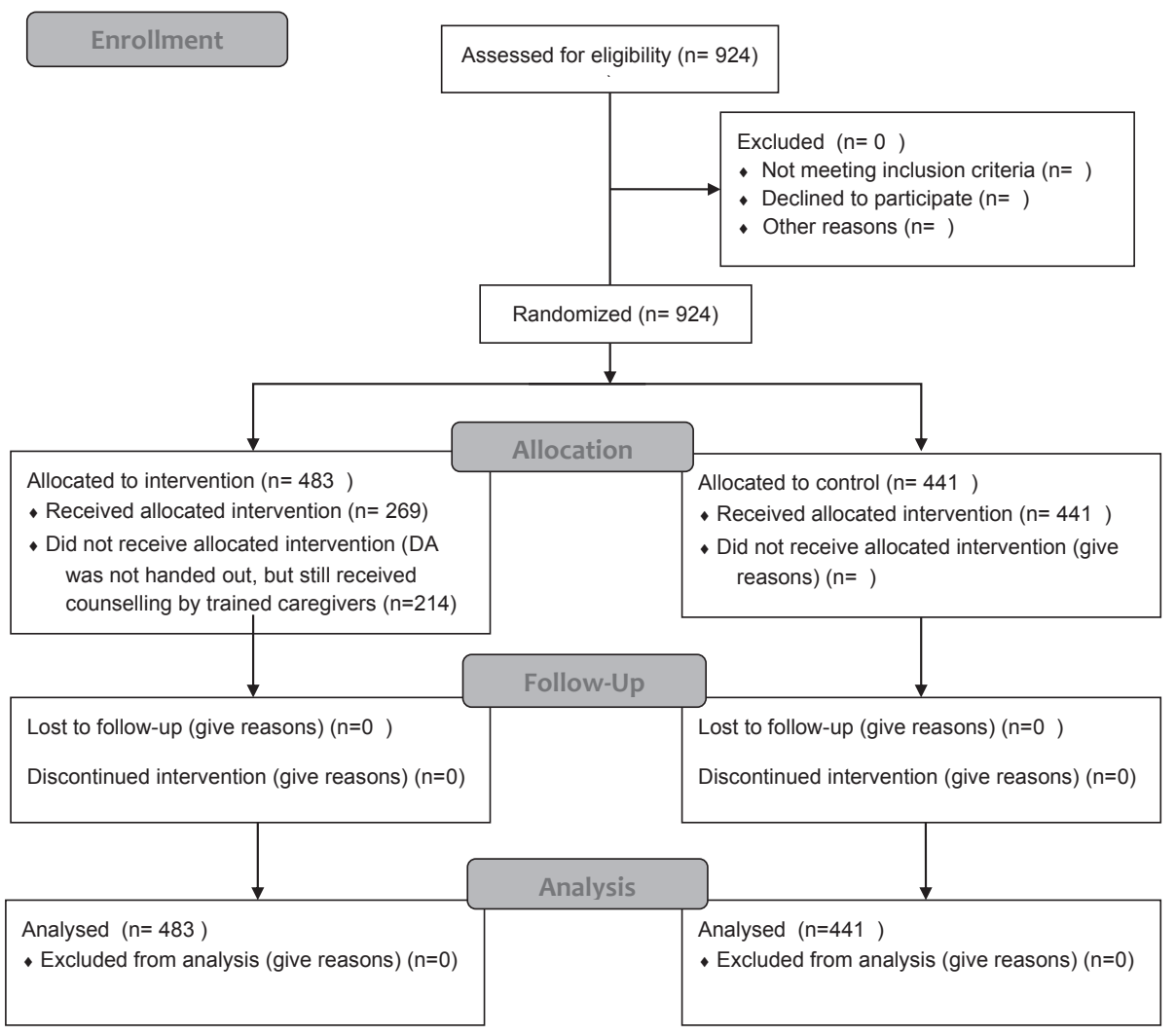

Fig 1. Consort flow diagram. Enrollment, allocation, follow-up and analysis 


\section{Secondary outcomes}

Table 3 shows the results of the different onsets of delivery. In the intervention group more women chose an ERCS (42\%) compared to the control group (31\%), (adjusted OR 1.6 [95\% Cl 1.18-2.17]) (intention to treat analysis). Of the women starting a TOL, in the intervention group the vaginal delivery rate was higher (77\%), compared to the control group (67\%) (adjusted OR 1.4 [ 95\% Cl 0.96-2.12]) (table 2). Subsequently, even after correction, the unplanned CS rate was lower in the intervention group (14\%) compared to the control group (23\%) (adjusted OR 0.57 [ 95\% Cl 0.40-0.82]). The per-protocol analysis showed similar results; the adjusted OR for an unplanned CS in the intervention group was 0.41 [95\% Cl 0.26-0.66]. In total 130/269 women chose for a TOL and 83\% had a VBAC compared to 67\% in the control group (adjusted OR 2.0 [95\% Cl 1.17-3.28]).

Regarding decision making, 256 out of 367 women ( $n=205$ in intervention group and $n=162$ in control group), filled in the questionnaire. Unfortunately, not all caregivers handed out the questionnaire and not all women replied, in spite of several reminders. In the intervention group 133 out of 137 (98\%) stated they were involved in the choice for the mode of delivery, compared to 78 out of $119(68 \%)$ in the control group ( $p$ < 0.001).

Table 4 shows the guideline adherence results based on intention to treat analysis. In the intervention group, counseling on mode of delivery was more frequently reported in the medical record (73\% vs. 63\%, p< 0.001), as were the specific required items ( $p<0.05)$. Of course, in a per-protocol analysis, all women received adequate information.

Table 5 shows the complication rates, which overall were low. When analyzing the total major complication rate, no significant differences were seen in uterine ruptures, perinatal deaths and asphyxia. The incidence of neonatal infection and the necessity for antibiotic treatment in women postpartum was comparable as well. 
Table 3. Onset of delivery outcome

\begin{tabular}{llllll}
\hline \multicolumn{7}{l}{ Intention to treat } & & \\
& $\begin{array}{l}\text { Intervention } \\
\mathbf{( N = 4 8 3 )} \mathbf{( \% )}\end{array}$ & $\begin{array}{l}\text { Control } \\
(\mathbf{N = 4 4 1 )} \mathbf{( \% )}\end{array}$ & $\begin{array}{l}\text { Crude OR } \\
(\mathbf{9 5 \%} \mathbf{C l})\end{array}$ \\
\hline Onset labor & & & & \\
\hline Elective repeat caesarean section & 201 & $41,6 \%$ & 137 & $31,1 \%$ & $1,6(1,21-2,07)$ \\
Spontaneous onset & 184 & $38,1 \%$ & 207 & $46,9 \%$ & $0,70(0,54-0,90)$ \\
Priming with balloon catheter & 45 & $9,3 \%$ & 35 & $7,9 \%$ & $1,2(0,75-1,89)$ \\
Priming with prostaglandins & 3 & $0,6 \%$ & 1 & $0,2 \%$ & $2,8(0,29-26,54)$ \\
Induction & 50 & $10,4 \%$ & 61 & $13,8 \%$ & $0,72(0,48-1,07)$ \\
\hline
\end{tabular}

OR: odds ratio, Cl: confidence interval, VBAC: vaginal birth after caesarean

Table 4. Guideline adherence

Items guideline adherence

Counseling documented in medical file

Chance of VBAC discussed

Small risk of uterine rupture discussed

Risk perinatal death discussed

Increased risk of uterine rupture in use of oxytocin or prostaglandins discussed

VBAC: vaginal birth after caesarean 
Per-protocol DA vs. control group

\begin{tabular}{|c|c|c|c|c|}
\hline $\begin{array}{l}\text { Adjusted OR ( } 95 \% \\
\mathrm{CI}) \text { (corrected for } \\
\text { risk factors) }\end{array}$ & \multicolumn{2}{|c|}{$\begin{array}{l}\text { Intervention } \\
(\mathrm{N}=269)(\%)\end{array}$} & $\begin{array}{l}\text { Crude OR } \\
(95 \% \mathrm{Cl})\end{array}$ & $\begin{array}{l}\text { Adjusted OR ( } 95 \% \\
\mathrm{CI}) \text { (corrected for } \\
\text { risk factors) }\end{array}$ \\
\hline $1,6(1,18-2,17)$ & 112 & $41,6 \%$ & $1,6(1,16-2,17)$ & $1,6(1,14-2,32)$ \\
\hline $0,58(0,43-0,78)$ & 100 & $37,2 \%$ & $0,67 \quad(0,43-0,88)$ & $0,60(0,42-0,86)$ \\
\hline $1,8(1,01-3,05)$ & 21 & $7,8 \%$ & $0,98(0,56-1,73)$ & $1,4(0,68-2,67)$ \\
\hline $3,1 \quad(0,29-32,20)$ & 2 & $0,7 \%$ & $3,3(0,30-36,52)$ & $3,6(0,31-41,37)$ \\
\hline $0,77(0,46-1,29)$ & 34 & $12,6 \%$ & $0,90(0,58-1,41)$ & $0,82(0,44-1,50)$ \\
\hline
\end{tabular}

\begin{tabular}{llllll} 
Intention to treat & \multicolumn{3}{l}{ Per protocol } \\
$\begin{array}{l}\text { Intervention } \\
\text { group (N=483) }\end{array}$ & $\begin{array}{l}\text { Control group } \\
\mathbf{( N = 4 4 1 )}\end{array}$ & $\mathbf{p}$-value & $\begin{array}{l}\text { Intervention } \\
\text { group } \\
\mathbf{( N = 2 6 9 )}\end{array}$ & $\begin{array}{l}\text { Control group } \\
\mathbf{( N = 6 5 5 )}\end{array}$ & p-value \\
\hline $353(73 \%)$ & $278(63 \%)$ & $p=0.01$ & $269(100 \%)$ & $362(55,3 \%)$ & $p<0,001$ \\
$295(61,1 \%)$ & $141(32,0 \%)$ & $p<0,001$ & $269(100 \%)$ & $167(25,5 \%)$ & $p<0,001$ \\
$288(59,8 \%)$ & $183(41,5 \%$ & $p<0,001$ & $269(100 \%)$ & $202(30,8 \%)$ & $p<0,001$ \\
$282(58,4 \%)$ & $118(26,8 \%)$ & $p<0,001$ & $269(100 \%)$ & $131(20 \%)$ & $p<0,001$ \\
$286(59,2 \%)$ & $185(42,0 \%)$ & $p<0,001$ & $269(100 \%)$ & $202(30,8 \%)$ & $p<0,001$ \\
\hline
\end{tabular}


Table 5. Incidence major complications

\begin{tabular}{|c|c|c|}
\hline & \multicolumn{2}{|c|}{$\begin{array}{l}\text { Intervention group } \\
(n=483)(\%)\end{array}$} \\
\hline \multicolumn{3}{|l|}{ Major maternal complications } \\
\hline$>4$ packed cells & 0 & $0 \%$ \\
\hline Uterine rupture & 6 & $1,2 \%$ \\
\hline Hysterectomy & 0 & $0 \%$ \\
\hline Operational injury & 0 & $0 \%$ \\
\hline Thrombosis & 0 & $0 \%$ \\
\hline Maternal death & 0 & $0 \%$ \\
\hline Admission ICU & 1 & $0,2 \%$ \\
\hline total & 7 & \\
\hline Patients with 1 or more maternal complications & 7 & $1,5 \%$ \\
\hline \multicolumn{3}{|l|}{ Major neonatal complications } \\
\hline Neonatal death & 0 & ०\% \\
\hline Neonatal asphyxia & 20 & $4,1 \%$ \\
\hline Plexus lesion or fracture & 0 & $0 \%$ \\
\hline Admission NICU & 9 & $1,9 \%$ \\
\hline total & 29 & \\
\hline Patients with 1 or more neonatal complications & 26 & $5,6 \%$ \\
\hline Total major complications & 36 & \\
\hline Patients with 1 or more major complications & 31 & $6,7 \%$ \\
\hline
\end{tabular}

Na.: not applicable, ICU: intensive care unit, NICU: neonatal intensive care unit 


7

$10 \quad 6$

$61,4 \%$

$\begin{array}{lll}0,2 \% & 0 & N a \\ 0,5 \% & 0 & 2,7(0,56-13,50) \\ 0 \% & 0 & N a .\end{array}$

$0,5 \%$

$\mathrm{Na}$.

$0,2 \%$

$0 \%$

2

$\mathrm{Na}$.

$0,5 \%$

3

$0,46(0,04-5,06)$

2

0
5
5
15

$20,5 \%$

$4,6 \%$

$0 \%$

$2,5 \%$

6

$1,1(0,36-3,17)$

20

0

11

33

16

25

$5,8 \%$

11

Na.

$0,91(0,50-1,66)$

$\mathrm{Na}$.

$0,76(0,32-1,81)$

41

21

27

$6,4 \%$

17

$1,05(0,64-1,74)$ 


\section{Discussion}

\section{Main findings}

This study showed that using the DA for the counseling on mode of delivery, does not result in a change in VBAC rates in a setting with a high VBAC rate. Fewer women chose a TOL, however the undesirable event of an unplanned CS was much less common. Although statistically non inferiority could not be proven and a change in VBAC incidence cannot completely be ruled out, we found an important shift from unplanned to planned CS. Women receiving the DA and choosing TOL in the intervention group succeeded more often than women choosing TOL in the control group. Women who received the DA felt more involved and were more often counseled according to the guidelines. This shows that the implementation of our DA results in a better risk-based choice of delivery and a more personalized counseling.

\section{Strengths and limitations}

This is the first study evaluating the use of a DA with a prediction model for mode of delivery after CS in a prospective, comparative setting. Several prediction models concerning vaginal birth after CS have been developed in the past [16-29]. However, none has been tested in practice as part of counseling. The DA itself was earlier tested according to the International Patient Aid Standards (IPDAS) and met 39/50 criteria $[11,30]$ because effectiveness measurements were not performed yet. By using it in a prospective setting the effectiveness can be evaluated as well. Taking this into account, the DA meets 46/50 IPDAS criteria [30]. Furthermore, our study included a large group of patients from different types of hospitals.

The design of our study was a prospective cohort study. Selection of the intervention hospitals was based on geographical region and VBAC results in usual care, which may cause bias. The reason this design was chosen instead of a cluster randomized trial is the fact that in a small country as the Netherlands, there is close collaboration between hospitals and midwifery practices. In this study setting referring midwives would not have to deal with two policies. Besides, caregivers like residents who work in different settings in one region during their specialization were not biased by knowledge of the use of the DA. A randomized controlled trial on patient level was not possible due to effects on knowledge and information bias by caregivers.

Only 56\% of the women in the intervention group received the DA, which can be explained by the fact that caregivers did not have sufficient attention to the DA in spite of instructions. To study the effect of the intervention as a whole and specifically the use of a DA, we performed both per-protocol analysis of the women who actually 
received the DA, and an intention-to-treat analysis showing that the effects were highest in women actually receiving the DA, but also were present in women that did not. This means that also effects on hospital level are present suggesting improved knowledge of caregivers or the use of the prediction model without the DA. As a result of the lack of compliance in the intervention group, differences between the groups are likely attenuated, leading to a lower statistical power than anticipated. However, table 2 shows that most clinically relevant associations, quantified as odds ratios, are accompanied by relatively small confidence intervals, and differences with respect to guideline adherence (table 4.) are all highly significant. This shows that the study still had sufficient power to detect meaningful differences between groups.

Only 256 out of 367 women who received the questionnaire returned it, in spite of several reminders. Although underpowered, no difference in the total incidence of complications between the two groups was observed. In general, complication risks are expected to be higher in an unplanned CS compared to elective CS a [9]. A benefit of using the DA on complication rate has to be studied in future research.

\section{Interpretation}

International guidelines stress that individual characteristics and preferences of the patient should be taken into consideration when counseling for mode of delivery [13]. The individual probability for a VBAC is a main determinant for the risk of severe maternal morbidity and an important factor in the decision-making process. This study showed that women in the intervention group choosing for TOL more often succeeded in VBAC. This might be an effect of the calculated individual probability, leading to a choice for TOL when the chance on VBAC is high. This would contribute to better risk selection. The effect of the DA and the prediction model was analyzed as one single intervention. Consequently, it is difficult to determine whether the results are due to the prediction model or improved counseling. However, according to the temporary guidelines, women should be informed about their chance on VBAC. Discussing their individual probability is therefore inseparable from adequate counseling. There was no selection bias in women who received the DA, when the predicted chances in both groups were similar. One of our future studies will focus on the impact of the use of the prediction model.

A DA is an effective instrument to support the shared decision-making process and helps patients to make an informed choice. In our study women who received the DA felt more involved in the decision making, however this was not tested in the beforesetting. Stacey et al. showed that patients felt more involved in the decision making process when a DA was used [31]. Shorten et al. showed increased knowledge and less 
decisional conflict in patients using a DA [32]. Montgomery et al. also showed reduced decisional conflict in women after using a DA, but no clear differences in mode of delivery [33]. Horey et al. reported no difference in preferred mode of delivery after interventions for supporting decision making [34]. Gardner et al. showed an increase in VBAC after implementation of two other strategies: a standing team of three high-risk consultants and an antenatal clinic for counseling women for mode of delivery after caesarean during three visits [35]. To the best of our knowledge this is the first study showing a change in not only the preferred mode of delivery but also in the actual mode of delivery after the use of a DA (more ERCS, less unplanned CS). These differences can be explained by the risk selection due to the incorporation of the prediction model. Besides the role in the decision-making process, the DA can help caregivers to inform patients according to the guidelines. In spite of the implementation of our intervention and a rise in counseling according to the guideline, there is still no complete guideline adherence in the intervention group. This might be due to the fact that the use of the DA was still in the implementation phase and the fear of caregivers for a rise in CS rate when counseling adequately.

The effects of the intervention in countries like the US, with an a priori low VBACrate are unclear. Patients possibly have other preferences, but particularly the cultural background and the preference of the healthcare providers might play a role. Besides, in this study, most of the women were Caucasian, who are more likely to delivery vaginally compared to Hispanic or African American women [4]. However, it is not unlikely that in countries with a Iower VBAC rate or other ethnicities, the use of a DA may also lead to a distinct decrease in CS.

\section{Conclusions}

In a setting with a high VBAC rate, a patient DA for mode of delivery after CS, appear to result in similar VBAC rates, but further research is necessary to prove non-inferiority. However, we found a higher successful TOL a lower unplanned CS rate and a higher ERCS rate. This suggests an improved risk selection. 


\section{References}

1. ACOG Practice bulletin no. 115: Vaginal birth after previous cesarean delivery. Obstet Gynecol, 2010. 116(2 Pt 1): 450-63.

2. NICE, Caesarean Section, clinical guideline. 2011, London: National Collaborating Centre for Women's and Children's Health.

3. RCOG, Birth after previous caesarean birth. Green-Top Guideline, 2015.

4. Guise JM, Eden K, Emeis C, Denman MA, Marshall N, Fu RR et al. Vaginal birth after cesarean: new insights. Evid Rep Technol Assess (Full Rep), 2010(191): 1-397.

5. MacDorman M, Declercq E, Menacker F, Recent trends and patterns in cesarean and vaginal birth after cesarean (VBAC) deliveries in the United States. Clin Perinatol, 2011. 38(2): 179-92.

6. Martin JA, Hamilton BE, Osterman MJ, Births in the United States, 2015. NCHS Data Brief, 2016(258): $1-8$.

7. Kwee A, Bots ML, Visser GH, Bruinse HW, Obstetric management and outcome of pregnancy in women with a history of caesarean section in the Netherlands. Eur J Obstet Gynecol Reprod Biol, 2007. 132(2): 171-6.

8. Melman S., Schoorel EC, de Boer K, Burggraaf H, Derks JB, van Dijk D, et al. Development and Measurement of Guidelines-Based Quality Indicators of Caesarean Section Care in the Netherlands: A RAND-Modified Delphi Procedure and Retrospective Medical Chart Review. PLoS One, 2016. 11(1): e0145771.

9. McMahon MJ, Luther ER, Bowes WA Jr, Olshan AF, Comparison of a trial of labor with an elective second cesarean section. N Engl J Med, 1996. 335(10): 689-95.

10. Schoorel EN, van Kuijk SM, Melman S, Nijhuis JG, Smits LJ, Aardenburg R, et al. Vaginal birth after a caesarean section: the development of a Western European population-based prediction model for deliveries at term. BJOG, 2014. 121(2): 194-201; discussion 201.

11. Schoorel EN, Vankan E, Scheepers HC, Augustijn BC, Dirksen CD, de Koning M, et al. Involving women in personalised decision-making on mode of delivery after caesarean section: the development and pilot testing of a patient decision aid. BJOG, 2014. 121(2): 202-9.

12. Vankan E, Schoorel EN, van Kuijk SM, Mol BJ, Nijhuis JG, Aardenburg R, et al. Practice variation of vaginal birth after cesarean and the influence of risk factors at patient level: a retrospective cohort study. Acta Obstet Gynecol Scand, 2016.

13. Kriston L, Scholl I, Holzel L, Simon D, Loh A, Harter M, The 9-item Shared Decision Making Questionnaire (SDM-Q-9). Development and psychometric properties in a primary care sample. Patient Educ Couns, 2010. 80(1): 94-9.

14. Ottawa Health Decision Centre. User manual-decisional conflict scale(s)

15. Montgomery AA, Emmett CL, Fahey T, Jones C, Ricketts I, Patel RR, et al. Two decision aids for mode of delivery among women with previous caesarean section: randomized controlled trial. BMJ 2007:334:1305.

16. Flamm, B.L.,A.M. Geiger, Vaginal birth after cesarean delivery: an admission scoring system. Obstet Gynecol, 1997. 90(6): 907-10.

17. Gonen R, Tamir A, Degani S, Ohel G, Variables associated with successful vaginal birth after one cesarean section: a proposed vaginal birth after cesarean section score. Am J Perinatol, 2004. 21(8): 447-53.

18. Grobman WA, Lai Y, Landon MB, Spong CY, Leveno KJ, Rouse DJ, et al. Development of a nomogram for prediction of vaginal birth after cesarean delivery. Obstet Gynecol, 2007. 109(4): 806-12. 
19. Grobman WA, Lai Y, Landon MB, Spong CY, Leveno KJ, Rouse DJ et al. Does information available at admission for delivery improve prediction of vaginal birth after cesarean? Am J Perinatol, 2009. 26(10): 693-701.

20. Jakobi P, Weissman A, Peretz BA, Hocherman I, Evaluation of prognostic factors for vaginal delivery after cesarean section. J Reprod Med, 1993. 38(9): 729-33.

21. Macones GA, Hausman N, Edelstein R, Stamilio DM, Marder SJ, Predicting outcomes of trials of labor in women attempting vaginal birth after cesarean delivery: a comparison of multivariate methods with neural networks. Am J Obstet Gynecol, 2001. 184(3): 409-13.

22. Metz TD, Stoddard GJ, Henry E, Jackson M, Holmgren C, Esplin S, Simple, validated vaginal birth after cesarean delivery prediction model for use at the time of admission. Obstet Gynecol, 2013. 122(3): 571-8.

23. Naji O, Wynants L, Smith A, Abdallah Y, Stalder C, Sayasneh A et al. Predicting successful vaginal birth after Cesarean section using a model based on Cesarean scar features examined by transvaginal sonography. Ultrasound Obstet Gynecol, 2013. 41(6): 672-8.

24. Pickhardt MG, Martin JN Jr., E.F. Meydrech EF, Blake PG, Martin RW, Perry KG Jr et al., Vaginal birth after cesarean delivery: are there useful and valid predictors of success or failure? Am J Obstet Gynecol, 1992. 166 (6 Pt 1): 1811-5; discussion 1815-9.

25. Smith GC, White IR, Pell JP, Dobbie R, Predicting cesarean section and uterine rupture among women attempting vaginal birth after prior cesarean section. PLoS Med, 2005. 2(9): e252.

26. Srinivas SK, Stamilio DM, Stevens EJ, Odibo AO, Peipert JF, Macones GA, Predicting failure of a vaginal birth attempt after cesarean delivery. Obstet Gynecol, 2007. 109(4): 800-5.

27. Tessmer-Tuck JA, El-Nashar SA, Racek AR, Lohse CM, Famuyide AO, Wick MJ, Predicting vaginal birth after cesarean section: a cohort study. Gynecol Obstet Invest, 2014. 77(2): 121-6.

28. Troyer LR, Parisi VM, Obstetric parameters affecting success in a trial of labor: designation of a scoring system. Am J Obstet Gynecol, 1992. 167(4 Pt 1): 1099-104.

29. Weinstein D, Benshushan A, Tanos V, Zilberstein R, Rojansky N, Predictive score for vaginal birth after cesarean section. Am J Obstet Gynecol, 1996. 174(1 Pt 1): 192-8.

30. Elwyn G, O'Connor A, Stacey D, Volk R, Edwards A, Coulter A et al., Developing a quality criteria framework for patient decision aids: online international Delphi consensus process. BMJ, 2006. 333(7565): 417.

31. Stacey D, Legare F, Col NF, Bennet CL, Barry MJ, Eden KB et al., Decision aids for people facing health treatment or screening decisions. Cochrane Database Syst Rev, 2014(1): CD001431.

32. Shorten AB, Shorten B, Keogh J, West S, Morris J, Making choices for childbirth: a randomized controlled trial of a decision-aid for informed birth after cesarean. Birth, 2005. 32(4): 252-61.

33. Montgomery AA, Emmett CL, Fahey T, Jones C, Ricketts I, Patel RR et al., Two decision aids for mode of delivery among women with previous caesarean section: randomized controlled trial. BMJ, 2007. 334(7607): 1305.

34. Horey D, Kealy M, Davey MA, Small R, Crowther CA, Interventions for supporting pregnant women's decision-making about mode of birth after a caesarean. Cochrane Database Syst Rev, 2013(7): CD010041.

35. Gardner K, Henry A, Thou S, Davis G, Miller T, Improving VBAC rates: the combined impact of two management strategies. Aust N Z J Obstet Gynaecol, 2014.54 (4): 327-32. 



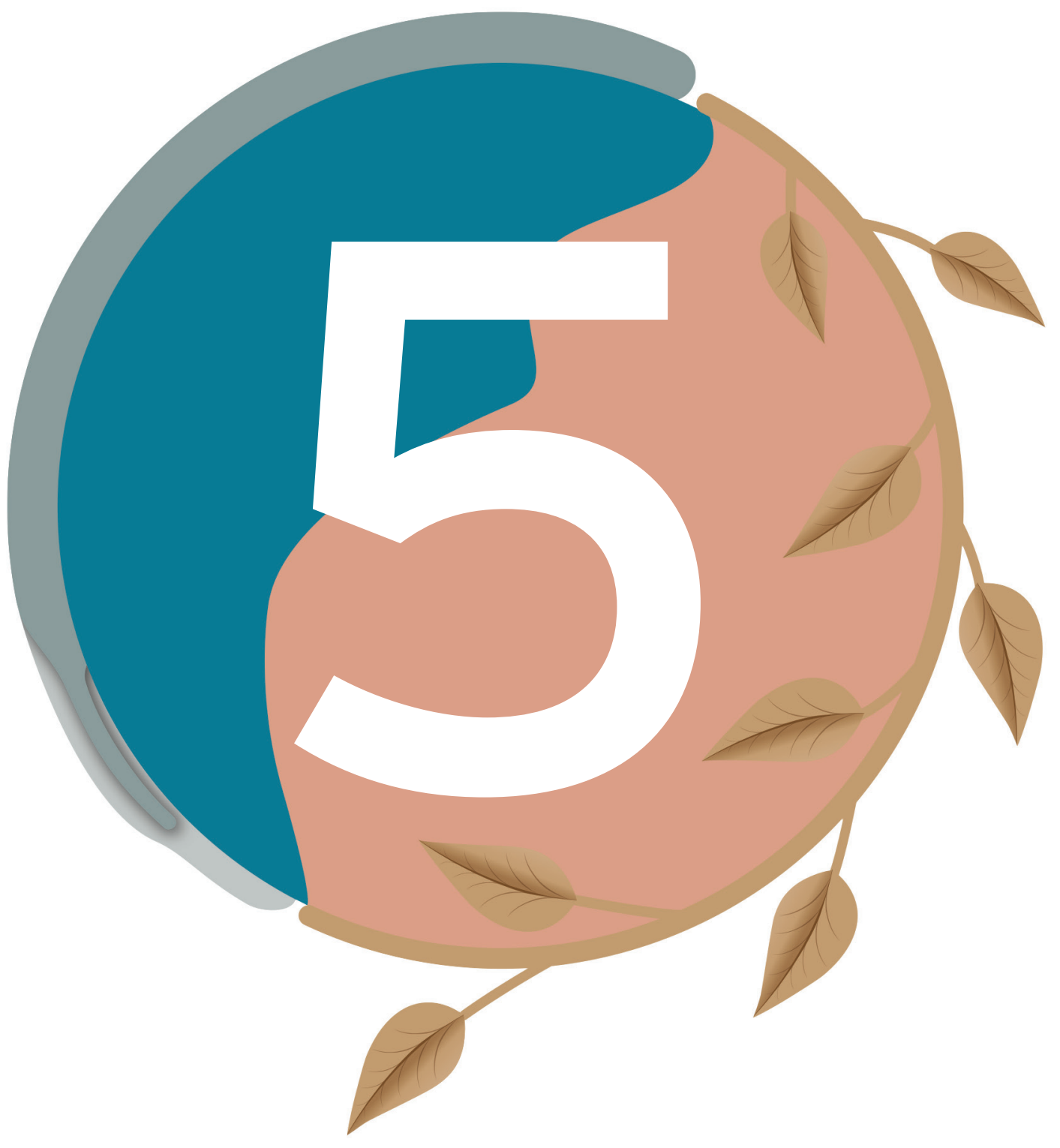


Chapter 5

\section{External validation of a prediction model on vaginal birth after caesarean in The Netherlands: a prospective cohort study}

Vankan E, van Kuijk SM, Nijhuis JG, Aardenburg R, Delemarre FM, Dirksen CD, van Dooren IM, Kuppens SM, Kwee A, Langenveld J, Schoorel EN, Smits LJ, Hermens RP, Scheepers HC

J Perinat Med. 2020 Nov 6;49(3): 357-363 


\section{Abstract}

\section{Objectives}

Discussing the individual probability of a successful vaginal birth after caesarean (VBAC) can support decision making. The aim of this study is to externally validate a prediction model for the probability of a VBAC in a Dutch population.

\section{Methods}

In this prospective cohort study in 12 Dutch hospitals, 586 women intending VBAC were included. Inclusion criteria were singleton pregnancies with a cephalic foetal presentation, delivery after 37 weeks and one previous caesarean section (CS) and preference for intending VBAC. The studied prediction model included six predictors: pre-pregnancy body mass index, previous vaginal delivery, previous CS because of non-progressive labour, Caucasian ethnicity, induction of current labour, and estimated foetal weight $\geq 90^{\text {th }}$ percentile. The discriminative and predictive performance of the model was assessed using receiver operating characteristic curve analysis and calibration plots.

\section{Results}

The area under the curve was 0.73 ( $\mathrm{Cl}$ 0.69-0.78). The average predicted probability of a VBAC according to the prediction model was $70.3 \%$ (range $33-92 \%$ ). The actual VBAC rate was $71.7 \%$. The calibration plot shows some overestimation for low probabilities of VBAC and an underestimation of high probabilities.

\section{Conclusions}

The prediction model showed good performance and was externally validated in a Dutch population. Hence it can be implemented as part of counselling for mode of delivery in women choosing between intended VBAC or planned CS after previous CS. 


\section{Introduction}

Contemporary guidelines propose that pregnant women who have had a previous cesarean section (CS) should be counselled about their choice of mode of delivery [1-3]. One of the key aspects in this counselling is discussing the probability of a successful vaginal birth after CS. Of all women who attempt a vaginal birth after CS (VBAC), it is postulated that 49-87\% achieve successful vaginal delivery [4]. However, this broad range makes challenging counselling based upon maternal personalised risk factors. Calculating the individual probability of a successful VBAC personalizes counselling and can support decision making. Women can take this individual probability into consideration when making an informed choice of mode of delivery.

Several models for predicting successful VBAC have been developed. Some of these models only include variables known early in pregnancy [5-7]. Other models also include variables known only close to delivery [8,9]. Earlier studies showed that the models that include close-to-delivery predictors discriminate better between success and failure of VBAC than the models only containing the predictors that are measured early on in pregnancy [8,10-12]. Schoorel et al. developed a prediction model including both variables known early in pregnancy and variables only known just before delivery. This model was developed and internally validated in a sample of 515 women from a Western European cohort [13]. Subsequently, the prediction model was included in a decision aid (DA) for counselling with regards mode of delivery [14] (Supplemental material). Implementation in a study setting showed an unchanged VBAC rate, but a better risk selection with a 40\% reduction in the unplanned caesarean section rate [15].

Before any prediction model is implemented in daily practice, it needs to be externally validated to assess the performance of the prediction model in an independent sample. We aimed to externally validate this prediction model for the probability of a VBAC in a Dutch population. If proven externally valid, the model can be implemented in daily practice for women choosing between intended VBAC en planned CS to individualise counselling for mode of delivery after one previous CS and help to improve case selection. 


\section{Material and methods}

\section{Prediction model}

The development of the prediction model and internal validation is described in the original article by Schoorel et al. [13]. In brief, all potential predictors of a successful VBAC were included in a multivariable logistic regression model with successful VBAC (yes or no) as the outcome variable. With backward stepwise elimination based on the Wald test, the number of predictors was reduced. Finally, six predictors were selected and combined into a prediction model. These six predictors were pre-pregnancy body mass index (BMI), previous vaginal delivery, previous CS because of non-progressive labour, Caucasian ethnicity, induction of current labour, and estimated foetal weight $\geq 90^{\text {th }}$ percentile. The model was internally validated and assessed by calculating the area under the curve (AUC) from receiver operating characteristic (ROC) curve analysis. The AUC was $70.8 \%$, indicating good discriminative ability. Visual inspection of the calibration plot showed that the model was well calibrated.

\section{Setting and design}

The current study is part of the Caesarean Section IMPLEmentation (SIMPLE) II study, a study to evaluate the use of a DA including the prediction model for mode of delivery after CS [15]. In this prospective cohort study in 12 Dutch hospitals, six hospitals in one region were assigned to use the DA [14] including the aforementioned Schoorel et al. prediction model [13] as part of the counselling for mode of delivery. These hospitals were compared with six matched (based on type and VBAC-rate) hospitals offering counselling without DA. [15] Different types of hospitals were represented: university hospitals $(n=2)$, teaching hospitals $(n=6)$ and non-teaching hospitals $(n=4)$. Furthermore, the hospitals had different intended VBAC-rates prior to the start of this study (( $\leq 60 \%$ (low),60-80\% (mean) and $\geq$ $80 \%$ (high)). This design was chosen to prevent bias caused by caregivers working in different hospitals in one region during the study period. As all these hospitals earlier recruited the women for the cohort study in which the prediction model was developed [13], this external validation can be seen as temporal validation. This shows the performance of the model in the setting in which the prediction model was developed, but on subsequent patients. The index study was a prospective cohort study performed between September 2012 and September 2014 including all patients from the SIMPLE II study opting for VBAC and intending VBAC to externally validate the Schoorel at al. prediction model [13]. 


\section{Study population}

The inclusion criteria for the current study were comparable to those of the cohort of Schoorel et al. [13] Eligible for inclusion were women with a singleton pregnancy with a foetus in cephalic position beyond 37 weeks of gestation and with a history of one previous CS. Furthermore, the women had to opt for an intended VBAC after counselling. Women were excluded if they were not able to read Dutch, if they preferred a planned CS or if there was a contra-indication for an intended VBAC. The contra-indications were defined as a previous classical vertical incision or other significant uterine scar, a previous uterine rupture, a suspected abruption of the placenta, impossibility of vaginal birth, e.g. cervical myoma, placenta praevia, vasa praevia or a primary infection with genital herpes simplex virus. All women meeting the inclusion criteria were recorded in an anonymised study database. Since the DA with the prediction model was used to improve guideline adherence [15], the Medical Ethical Committee of the MUMC+ agreed that obtaining individual informed consent was not necessary.

\section{Sample size}

There are no formulas available to compute the required sample size for an external validation study. Some simulation studies on sample size exist and results are often transformed into a generic rule-of-thumb that states that at least 100 events and 100 non-events should be available for the analysis [16]. Because of the size of the available cohort we had ample precision to compute estimates of model performance. An event was defined as an unsuccessful trial of labour, which occurred 166 times in this cohort. Hence, both the number of successes and failures were well over 100.

\section{Data collection}

Data on patient characteristics (ethnicity, age, BMI, obstetric history and features of the current pregnancy) the variables contained in the prediction model (see above), and mode of delivery were collected from the birth registration in each hospital by trained staff and research nurses. Regarding the patient characteristic ethnicity, in birth registrations in the Netherlands seven categories of ethnicity are used: Dutch, Mediterranean, other European, African, Asian, Hindu, and "other". In both the development and external validation cohorts, Caucasian ethnicity was defined as "Dutch" and "other European". Because data were collected from the same type of birth registrations, converting or redefining of the other collected data was not necessary. A successful VBAC is defined by a woman starting intended VBAC and ending having a vaginal birth. When a woman starts intended VBAC, but finally has an unplanned CS is defined as a failed VBAC. This was consistent at all the participating hospitals 


\section{Statistical analyses}

Missing covariate data were imputed using stochastic regression imputation, since complete case analysis decreases statistical power and may induce bias if data are not missing completely at random [17]. The performance of the prediction model was quantified by several measures. The ability to discriminate between women who will succeed and those who will not was expressed as the area under the receiver operating characteristic (ROC) curve (AUC). The difference between the average predicted probability and observed frequency was used to determine calibration in the large. Furthermore, a calibration plot was made to visually assess the models' agreement between predicted probabilities and actual probabilities. The Hosmer-Lemeshowstatistic was used to determine the goodness of fit of the prediction model. This is a goodness of fit test for logistic regression, showing how well the data fits the prediction model. Specifically, the HL test calculates if the observed event rates match the expected event rates in population subgroups. All statistical analyses were performed using SPSS version 21. The calibration plot was constructed using $\mathrm{R}$ version 3.2.3.

\section{Ethical approval}

Ethical approval for this study was obtained from the Medical Ethical Committee of the Maastricht University Medical Centre+ (MUMC+) in The Netherlands (MEC number 12-4-091) (18-04-13).

\section{Trial registration}

This study is registered at ClinicalTrials.gov: Current Dutch Practice on Caesarean Sections: Identification of Barriers and Facilitators for Optimal Care (SIMPLE), NCT01261676, https://clinicaltrials.gov//show/NCT01261676?term=cesarean\&rank=18. 


\section{Results}

\section{Study population}

Of the 924 women pregnant after previous CS and eligible for VBAC in the original cohort, 586 (63\%) women opt for and started intended vaginal delivery and were hence included for this study. Four hundred and twenty women had a successful VBAC (72\%) and 166 (28\%) had an unplanned CS. Baseline characteristics are shown in table 1. Women who had a successful VBAC had a lower BMI, had more often a previous vaginal delivery and were less likely to have a foetus with an estimated foetal weight $>90^{\text {th }}$ percentile or a previous cesarean section because of failure to progress. Furthermore, they were less likely to have an induction.

\section{External validation}

The area under the ROC curve was 0.73 ( $\mathrm{Cl}$ 0.69-0.78) (Fig. 1), expressing the discriminative ability of the prediction model for VBAC. The average predicted probability of a VBAC according to the prediction model was $70.3 \%$ (range $33-92 \%$ ). The actual VBAC rate in this cohort was $71.7 \%$. Therefore, as calibration in-the-large was close to zero, we did not observe evidence of systematic under- or overestimation of the probability. The calibration plot did show some proportional miscalibration: a small overestimation for low probabilities of VBAC and an underestimation of high probabilities (Fig 2). Interpretation of figure 2 shows a slight overestimation of the probability of a successful VBAC when the probability of success is lower than $60 \%$. The $\mathrm{HL}$ statistic to assess the goodness of fit, showed a P-value of 0.11 , indicating sufficient calibration of the prediction model. 
Table 1. Baseline characteristics

\begin{tabular}{|c|c|}
\hline & Successful VBAC \\
\hline & $N=420$ \\
\hline & $\mathrm{N}(\%)$ or mean $(+/-\mathrm{SD})$ \\
\hline Caucasian ethnicity & $327(78.6)$ \\
\hline Maternal age (years, mean) & $33.6(4.3)$ \\
\hline Pre-pregnancy BMI (mean) & $25.1(5.2)$ \\
\hline$<18,5$ & 13 \\
\hline $18,5-24,9$ & 189 \\
\hline $25,0-29,9$ & 81 \\
\hline$>30$ & 54 \\
\hline \multicolumn{2}{|l|}{ Obstetric history } \\
\hline Parity (median) & $1(0.9)$ \\
\hline Indication previous CS failure to progress & $132(33.8)$ \\
\hline Previous vaginal birth & $125(30.5)$ \\
\hline Previous vaginal birth after CS & $91(22.5)$ \\
\hline \multicolumn{2}{|l|}{ Current pregnancy } \\
\hline Gestational diabetes & $13(3.1)$ \\
\hline Pre-existent or pregnancy induced hypertension & $32(7.7)$ \\
\hline Pre-eclampsia/ HELLP & $7(1.7)$ \\
\hline Estimated foetal weight from GA 32 p $\geq 90$ & $15(3.9)$ \\
\hline Estimated foetal weight from GA $32 \leq \mathrm{p} 10$ & $19(5.0)$ \\
\hline Induction of labour & $117(31.5)$ \\
\hline
\end{tabular}




\begin{tabular}{|c|c|c|}
\hline Failed VBAC & Missing* & p-value \\
\hline $\begin{array}{l}N=166 \\
N(\%) \text { or mean }+/-S D)\end{array}$ & $3 / 0$ & \\
\hline 119 (73.0) & $1 / 3$ & 0.16 \\
\hline $33.9(4.4)$ & $13 / 5$ & 0.51 \\
\hline $26.6(5.2)$ & $80 / 31$ & \\
\hline 1 & & 0.08 \\
\hline 59 & & 0.02 \\
\hline 41 & & 0.16 \\
\hline 34 & & 0.026 \\
\hline $1(0.4)$ & $2 / 1$ & 0.00 \\
\hline $88(55.0)$ & $27 / 6$ & 0.00 \\
\hline $9(5.4)$ & $7 / 0$ & 0.00 \\
\hline $4(2.4)$ & $12 / 2$ & 0.00 \\
\hline $6(3.6)$ & $3 / 0$ & 0.80 \\
\hline $14(8.4)$ & $3 / 0$ & 0.74 \\
\hline $7(4.2)$ & $5 / 0$ & 1.29 \\
\hline $17(10.8)$ & $35 / 9$ & 0.00 \\
\hline $7(4.4)$ & $35 / 8$ & 1.00 \\
\hline 55 (38.7) & $46 / 24$ & 0.14 \\
\hline
\end{tabular}




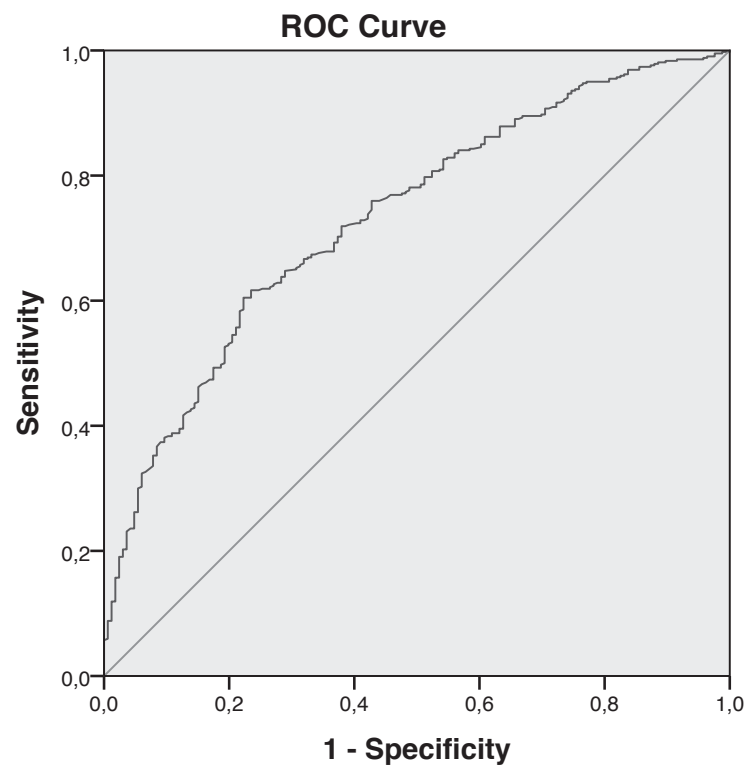

Diagonal segments are produced by ties.

Figure 1. Receiver Operating Characteristic curve. Area under the curve: 0.73 (Cl 0.69-0.78).

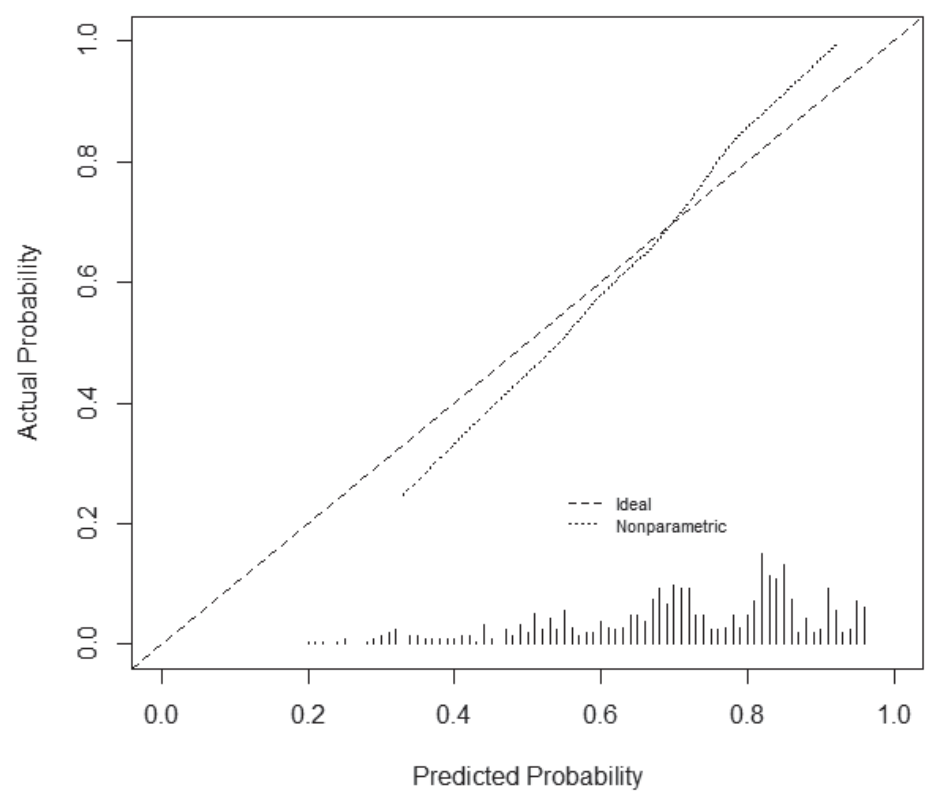

Figure 2. Calibration plot with the observed probability of a vaginal birth after caesarean (VBAC) by the predicted probability of a VBAC by the prediction model. 


\section{Discussion}

\section{Main Findings}

This study shows the external validation of a prediction model for VBAC developed by Schoorel et al [13]. The discriminative performance of the model is good and even improved slightly in the validated model to an AUC of 73\%, compared to an optimismcorrected AUC of $71 \%$ in the developed model [13]. The HL-statistic was non-significant, indicating good calibration. Temporal validation is proven, because the model was validated in the same setting in which the model was developed. In women with a high probability of VBAC, the prediction model on average slightly underestimates their probability and conversely, in women with a low probability of VBAC, their VBAC probability was slightly overestimated by the prediction model. At internal and external validation, the model showed a slight overestimation of the probability of a successful VBAC when the probability of success is lower than $60 \%$.

\section{Strengths and Limitations}

One of the strengths of this study is that this model has been used in a prospective setting as part of the counselling for mode of delivery after a previous CS in eligible women. In the prospective setting, use of the model suggests a risk reduction in unplanned cesarean [15]. By showing the prediction model is externally valid we proved that it can be implemented in daily practice for a personalized counselling of women pregnant after a previous CS in the third trimester of pregnancy choosing mode of delivery.

Furthermore, this study was performed in a prospective setting in multiple centres, which contributes to a higher validity of the study results. The externally validated model was previously developed in a Dutch sample. Because the external validation took place in the same hospitals but after the development of the model, there was no need to convert or redefine variables because of differences in definitions or measurements.

A limitation of this study was that the model has only been validated in Dutch hospitals, a population with a high VBAC rate $(38-46 \%)[15,18]$. The discriminative performance may change when applied to samples from other populations because of other patient characteristics and preferences and other policies concerning mode of delivery after previous CS $[6,12]$. Besides, the clinical impact of this model used in a prospective setting on VBAC rate and risk reduction has not been studied in other countries yet.

Self-selection bias based on women with a high risk on an unplanned CS cannot be ruled out. Women with a low chance on VBAC might prefer a planned CS. Hence, women opting for intended VBAC possibly have a higher chance on VBAC. When we compare 
the baseline characteristics of this study cohort with the control group of the SIMPLE II study [15], women in this cohort seem to have more often a BMI lower than 25, less often had a previous CS because of failure to progress and more often had a previous vaginal birth. These factors are positive predictors for VBAC. However, age and parity were comparable and women in this cohort more often had an induction of labour, which is a negative predictor for VBAC. Besides, it is unknown if these differences are significant. The intended VBAC rate (63\%) is comparable with the intended VBAC rate in the cohort study in which the prediction model was developed (67\%) [13]. Further research of the impact of the predicted chance on VBAC on the decision for mode of delivery is necessary.

\section{Interpretation}

A model with a good discriminative performance between patients with a high probability of a VBAC and those with a low probability can contribute to a decrease in unplanned CS and consequently a decrease in maternal and foetal morbidity [19]. Vankan et al. already showed a reduction in unplanned CS when this prediction model is used as part of a decision aid, without a clear change in VBAC rate [15].

To make a distinction between a high and a low probability of VBAC and, consequently between equal or less and more maternal morbidity than with an elective (planned) repeat caesarean section, a cut-off point might be helpful in counselling patients and risk estimation. Several studies researched this issue; however, a clear cut off point has not been defined yet. Grobman et al. [20] showed increased total and minor maternal morbidity when the probability of VBAC was lower than $70 \%$ and increased major maternal and neonatal morbidity when the probability of VBAC was lower than $60 \%$. These results were derived when using a prediction model with factors known early in pregnancy. When the same model was used in a different population, increased maternal morbidity was demonstrated when the probability of VBAC was lower than $60 \%$ and there was increased neonatal morbidity when the probability of VBAC was lower than 70\% [21]. Metz et al. used a model with close to delivery variables and made a distinction between a low probability (<50\%) and a high probability (>85\%) [22]. However, these cut off points were not directly related to morbidity rates. Our cohort is likely too small to draw conclusions about morbidity rates. Furthermore, the risk of morbidity is only one factor contributing to women's choices. Previous experiences and personal preferences are different and are likely to result in different risk appreciation. For some women a $60 \%$ chance of vaginal birth is considered high while others find it low. 
The model performance in predicting a successful VABC, indicated by the AUC, was 0.733. If we compare this to other developed models, most of them had a similar or lower discriminative ability when they were externally validated. [5, 6, 9-11, 21, 23]. A few had a higher discriminative ability $[10,12,22]$.

Metz et al validated their own model in a retrospective study in multiple hospitals, which included early known variables and a variable known close to delivery and found a concordance statistic of 0.80 at external validation [22]. However, the close-to-delivery variable was only known at admission for delivery, which makes this model less suitable for counselling in the third trimester. Yokoi et al. externally validated the entry-to-care model of Grobman in Japanese women in one tertiary referral hospital and found a concordance-statistic of 0.81 , but these results are not applicable for a Western European population [12]. Constantine et al [10] found a concordance statistic of 0.76 when validating the close-to-delivery model of Grobman at one university hospital in the United States.

In both the studies of Metz and Yokoi a high percentage of VBAC was found in their population as we found in our study $[12,22]$. The models were only tested in populations of patients who choose a trial of labour. This could indicate selection-bias, because patients with a low probability of VBAC might not choose an intended VBAC. Our model showed an overestimation for low probabilities of VBAC. The model of Metz and the close-to-delivery model of Grobman also showed more variance in the low probabilities of $\operatorname{VBAC}[8,21]$. These findings make the models less accurate for patients with a Iow probability of VBAC. Fagerberg et al, who validated an adapted version of the entry-to-care model of Grobman showed a better correlation between predicted and observed VBAC-rates in women with low probabilities of VBAC compared to the original model of Grobman [6]. The discriminative ability of this model was comparable to the discriminative ability of our model.

Several studies show that validating the same model in different countries can change the discriminative ability of a prediction model $[5,6,10,11,12,21,23]$. Further research is necessary to explore if similar results can be achieved in different settings.

\section{Conclusion}

This study externally validated a prediction model for mode of delivery after a previous CS in a Dutch population, showing good performance. The prediction model can be implemented as part of counselling in women choosing mode of delivery after previous CS in the Netherlands. 


\section{References}

1. Gynaecologists, R.C.o.O.a., Birth after previous caesarean birth. Green-Top Guideline, 2015;45.

2. ACOG Practice bulletin no. 115: Vaginal birth after previous caesarean delivery. Obstet Gynecol, 2010;116:450-63.

3. Excellence, N.I.f.H.a.C., Caesarean section. NICE Guidelines, 2011(November).

4. Guise JM, Eden K, Emeis C, Denman MA, Marshall N, Fu RR, et al. Vaginal birth after caesarean: new insights. Evid Rep Technol Assess (Full Rep), 2010;191:1-397.

5. Annessi E, Del Giovane C, Magnani L, Carossino E, Baldoni G, Battagliarin G, et al. A modified prediction model for VBAC, in a European population. J Matern Fetal Neonatal Med, 2016;29:435-9.

6. Fagerberg MC, Marsal K, Kallen K, Predicting the chance of vaginal delivery after one caesarean section: validation and elaboration of a published prediction model. Eur J Obstet Gynecol Reprod Biol, 2015;188:88-94.

7. Grobman, WA, Lai Y, Landon MB, Spong CY, Leveno KJ, Rouse DJ, et al. Development of a nomogram for prediction of vaginal birth after caesarean delivery. Obstet Gynecol, 2007;109:806-12.

8. Grobman WA, Lai Y, Landon MB, Spong CY, Leveno KJ, Rouse DJ, et al. Does information available at admission for delivery improve prediction of vaginal birth after caesarean? Am J Perinatol, 2009;26:693-701.

9. Smith GCS, White IR, Pell JP, Dobbie R, Predicting caesarean section and uterine rupture among women attempting vaginal birth after prior caesarean section. PLoS Med, 2005;2:e252.

10. Costantine MM, Fox KA, Pacheco LD, Mateus J, Hankins GDV, Grobman WA, et al. Does information available at delivery improve the accuracy of predicting vaginal birth after caesarean? Validation of the published models in an independent patient cohort. Am J Perinatol, 2011;28:293-8.

11. Schoorel ENC, Melman S, van Kuijk SMJ, Grobman WA, Kwee A, Mol BWJ, et al. Predicting successful intended vaginal delivery after previous caesarean section: external validation of two predictive models in a Dutch nationwide registration-based cohort with a high intended vaginal delivery rate. BJOG, 2014;121:840-7; discussion 847.

12. Yokoi A, Ishikawa K, Miyazaki K, Yoshida K, Furuhashi M, Tamakoshi K, Validation of the prediction model for success of vaginal birth after caesarean delivery in Japanese women. Int J Med Sci, 2012:9:488-91.

13. Schoorel ENC, van Kuijk SMJ, Melman S, Nijhuis JG, Smits LJM, Aardenburg R, et al. Vaginal birth after a caesarean section: the development of a Western European population-based prediction model for deliveries at term. BJOG, 2014;121:194-201; discussion 201.

14. Schoorel ENC, Vankan E, Scheepers HCJ, Augustijn BCC, Dirksen CD, de Koning M, et al. Involving women in personalised decision-making on mode of delivery after caesarean section: the development and pilot testing of a patient decision aid, BJOG: an international journal of obstetrics and gynaecology, 2014 Jan;121:202-9

15. Vankan E, Schoorel E, van Kuijk S, Nijhuis J, Hermens R, Scheepers H, et al. The effect of the use of a decision aid with individual risk estimation on the mode of delivery after a caesarean section: A prospective cohort study, PloS one,2019 Sep 26;14:e0222499

16. Vergouwe Y, Steyerberg EW, Eijkemans MJC, Habbema JDF, Substantial effective sample sizes were required for external validation studies of predictive logistic regression models, Clin Epidemiol, 2005; 58: 475-83

17. Rippe RCA, Heijer, den M, Cessie, le S, Imputation of missing data, Ned Tijdschr Geneeskd, 2013; 157: A5539 
18. Euro-Peristat Project, European Perinatal Health Report, Core Indicators of the health and care of pregnant women and babies in Europe in 2015, November 2018. Available www.europeristat.com

19. McMahon MJ, Luther ER, Bowes WA Jr, Olshan AF, Comparison of a trial of labour with an elective second caesarean section. N Engl J Med, 1996;335:689-95.

20. Grobman WA, Lai Y, Landon MB, Spong CY, Leveno KJ, Rouse DJ, et al. Can a prediction model for vaginal birth after caesarean also predict the probability of morbidity related to a trial of labour? Am J Obstet Gynecol. 2009 Jan;200:56.e1-6.

21. Chaillet N, Bujold E, Dubé E, Grobman WA, Validation of a Prediction Model for Predicting the Probability of Morbidity Related to a Trial of Labour in Quebec, J Obstet Gynaecol Can 2012;34:820825

22. Metz TD, Stoddard GJ, Henry E, Jackson M, Holmgren C, Esplin S, Simple, validated vaginal birth after caesarean delivery prediction model for use at the time of admission, Obstet Gynecol. 2013 Sep;122:571-8.

23. Mone F, Harrity C, Mackie A, Segurado R, Toner B, McCormick TR, et al. Vaginal birth after caesarean section prediction models: a UK comparative observational study, European journal of obstetrics, gynecology, and reproductive biology, 2015 Oct;193:136-9. 


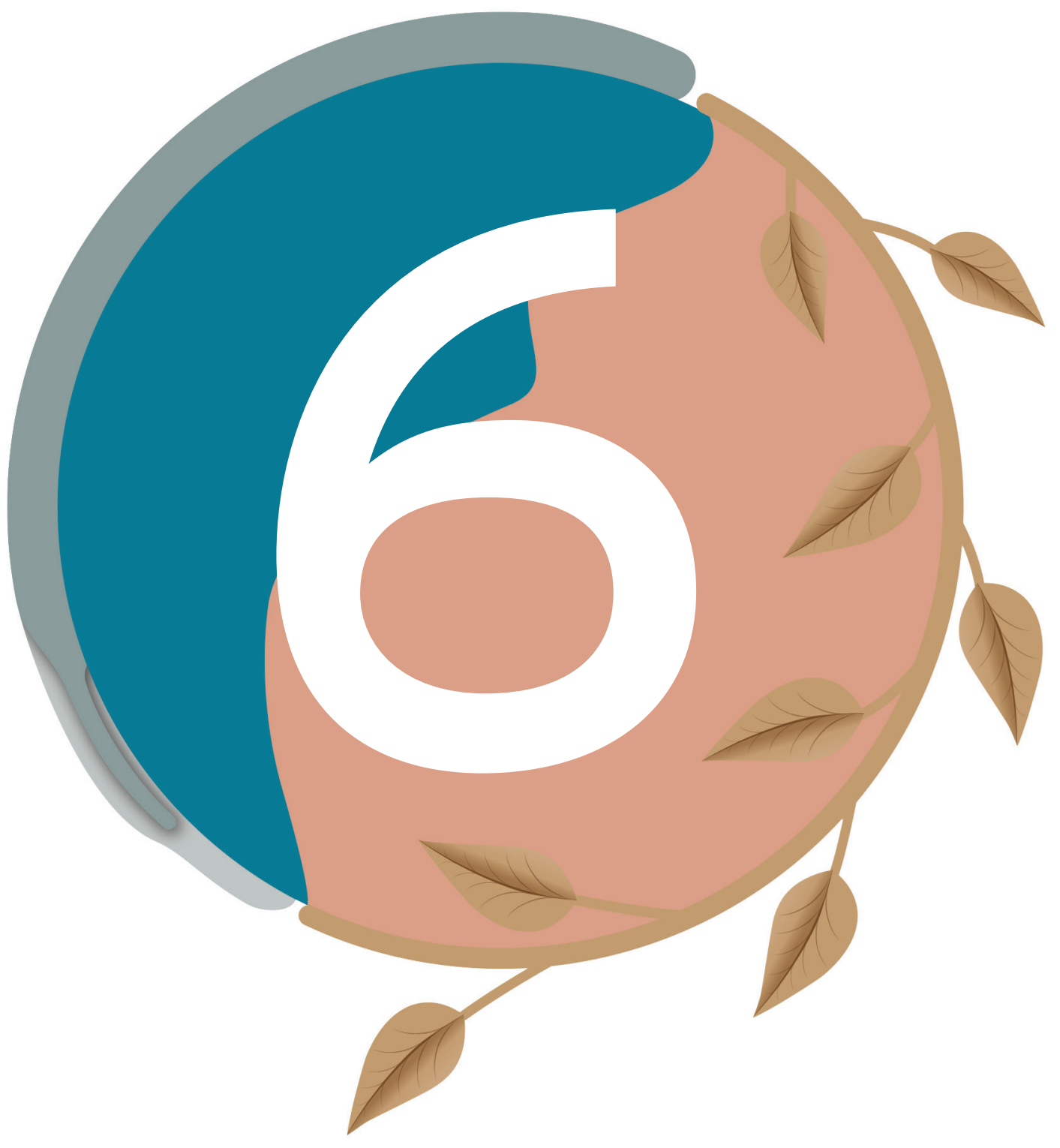


Chapter 6

Summary and

General Discussion 


$$
\text { . }
$$




\section{Summary and General Discussion}

The worldwide increase in caesarean rate leads to a rise in the number of women pregnant after a previous CS. Despite clear guidelines indicating that these women have to be informed about their options in mode of delivery, Melman et al. showed low guideline adherence in this group of women: only 15\% was adequately informed [1]. In our study we revealed a large variation between Dutch hospitals regarding the number of VBAC and planned CS after previous CS (chapter 1). In answer to our research question, this variation can only partially be explained by factors at patient level (research question 1). Factors at provider level, like counseling, or hospital level could play a role. For example, caregivers could fear a rise in CS rate when they inform women according to the guidelines [2].

The main goal of this thesis is to develop an intervention with the aim to increase guideline adherence, enhance patient involvement and reduce practice variation in mode of delivery after caesarean. Mode of delivery is ideally discussed in a shared decision-making setting. The decision making is complex because it concerns the health of both the pregnant woman and her unborn child.

A decision aid (DA) is considered to be an effective tool in shared decision making for mode of delivery and increases involvement en knowledge of patients $[3,4]$. We systematically developed a decision aid according to the IDPASS criteria [5], based on evidence-based information and in agreement with the current guidelines [6-8] (research question 2). In this way the DA can also be used as a guideline implementation tool.

Discussing the chance on a vaginal birth after caesarean is one of the key points in counseling for mode of delivery [6-8]. Since the average chance of VBAC is not applicable to an individual woman, we added a prediction model for calculating the individual chance of VBAC to the decision aid [9]. The goal of the prediction model is to contribute to more personalized counseling and informed decision making as well as to visualize potential risks. This is the first DA for mode of delivery after previous CS with an integrated prediction model (research question $\mathbf{2}$ ). The pilot test showed that women evaluate the DA to be clear, informative and relevant (chapter 2).

The DA was applied in a prospective setting with the hypothesis that adequately counseling women for mode of delivery will not decrease VBAC rates (chapter 3). We explored the effect of implementing the DA on the VBAC-rate, patient involvement decision making, guideline adherence and maternal and neonatal complications 
(research question 3). The use of the DA indeed led to unchanged number of VBAC's. However, there was a significant decrease in unplanned CS and an increase in planned CS. Women opting for a trial of labour more often had a successful VBAC. This suggests that women with a high chance of VBAC more often chose TOL and women with a low chance on VBAC more often chose a planned CS. In this way the DA can contribute to a better risk-selection, since an unplanned CS has the highest risks on morbidity [10]. Women who received the DA felt more involved in decision making and guideline adherence was increased while using the DA. We are the first to study the use of DA with integrated prediction model in a prospective setting, showing an effect in the choice for mode of delivery and actual mode of delivery. Whether these effects are consistent when the DA is implemented at national level need to be analyzed in a before- and after study.

Before the prediction model can be implemented in daily care, it needs to be validated externally (research question 4). We analyzed the performance of the model in an independent Dutch population (chapter 4). The discriminative performance of the model was good, which means the model can discriminate between women with a high chance and women with a low chance of VBAC. This can contribute to decision making and to a decrease in unplanned VBAC. Several studies have been performed researching a cut-off point between high and Iow probability of VBAC, but it has not yet been defined [11-13]. A cut-off point could support counseling and risk estimation. However, personal experiences and preferences of the patient play an important role as well. The impact of the personal probability of a VBAC on the final decision needs to be explored in future studies. 


\section{Methodological issues}

A strength of our cohort studies was that a large number of patients was included in 12 to 17 hospitals different types throughout the Netherlands. Academic, teaching and non-teaching hospitals were included, representing a good reflection of the Netherlands and contributing to a higher validity of these studies.

The study of practice variation showed there is large variation in mode of delivery in the Netherlands, while only a part of the variation can be explained by factors at patient level. Strengths of this study were that a total of 17 hospitals of different types were included, representative for the national distribution and that the data were collected systematically. The selection of predictive variables for VBAC was in line with current insights within predictive research. A limitation of this study was the risk of missing contributing predictive variables by choosing stepwise elimination for predictor selection. The eliminated predictors at patient level could still play a role in practice variation. Furthermore, due to lack of data, the exact amount of practice variation explained by factors at hospital or provider levels could not further be specified. Although additional analysis was performed where hospitals were clustered by type, this remains a rough measurement.

The DA was developed using a systematic process according to the international patient decision aid standards (IPDAS) criteria. The content was selected from evidence-based information and the contemporary guidelines on mode of delivery after CS. In this way it can also be used as a guideline implementation tool. The DA was critically reviewed by an expert panel and pilot-tested by 25 women, who valued the DA to be supportive in the decision-making process. A weakness of the pilot study is the fact that is was performed in only one tertiary center. Only a small number of women with low SES participated. Furthermore, the DA was not distributed as part of regular care.

Since more extended research to the DA was desirable, we chose to introduce the DA in a larger population in a prospective setting. In this manner effectiveness measurements could be performed, with the result that the DA now meets 46 of the 50 IPDAS criteria. Though the point estimate suggests that the use of the DA did not decrease VBAC beyond the non-inferiority limit, the results are not conclusive because of wide confidence intervals. However, an important shift from unplanned to planned CS was noticed, suggesting a better risk-based choice. 
In this prospective cohort study, selection of the intervention hospitals was based on geographical region and VBAC rates, which may cause bias. The reason for the choice of this design was the fact that in a small country as the Netherlands, there is close collaboration between hospitals and midwifery practices. In the chosen setting referring midwives would not have to deal with two policies. Furthermore, caregivers like residents who work in different settings in one region during their specialization were not biased by the knowledge of the use of the DA.

In the intervention group, only 56\% women received the DA, leading to a lower statistical power than anticipated. However, the most clinically relevant associations, like planned CS and unplanned CS, are accompanied by relatively small confidence intervals. Use of the DA shows effects on choice in mode of delivery and actual mode of delivery. The effect of the DA was also present in patients who did not receive the DA, suggesting improved knowledge of caregivers.

The study concerning external validation of the prediction model was performed in a prospective setting in multiple centers, contributing to a higher validity of the study results. The development of the prediction model and the external validation took place in the same hospitals, which reduces the chance of differences in definitions or measurements. The model is externally validated in a Dutch population which is known for its high VBAC rate. The performance of the model may change when it is applied to other populations. A limitation of this study is that self-selection bias cannot be ruled out. Women with a high risk of an unplanned CS might prefer a planned CS. Hence, women choosing for TOL possibly have a higher chance on VBAC. 


\section{Implications for daily practice}

The DA supports the communication about the mode of delivery between the caregiver and the pregnant woman and enhances patient involvement in decision making. Furthermore, it offers a tool for the caregiver to counsel according to the current guidelines. There is no reason to fear an increase in CS, since this thesis shows no change in CS and shows a reduction in unplanned CS. The DA is a useful tool for counseling women pregnant after CS performed in the third trimester of pregnancy.

The next step is to examine if the results are consistent when the DA is used in daily practice. Koppes et al. performed an implementation study in which the DA was implemented in daily care in 30 Dutch hospitals [14]. This study showed a reduction in practice variation in VBAC in the hospitals included. The CS rate remained unchanged and there was no rise in complication rate.

The DA can now be implemented in daily practice in the Netherlands. The DA is available for patients at the website of the NVOG and is included in the national guideline concerning pregnancy and delivery after previous CS. In this way the DA is easily accessible for patients and caregivers. 


\section{Implications for future research}

All these studies were performed in the Netherlands, a country with a high VBAC rate. Whether the DA and the prediction model have the same effect in other populations needs to be further explored. Several factors play a role in the choice for VBAC. For example ethnicity: Caucasian women, representing the largest group in our studies, are more likely to have a vaginal delivery compared to Hispanic or African American women [15]. Cultural background, access to a hospital and professional liability are also of influence on the VBAC rate. Studies exploring the effect of the DA and the performance of the prediction model in populations with different backgrounds, ethnicity or organization of healthcare can give more insight in the usability of the DA and prediction model worldwide.

The impact of the chance on VBAC calculated by the prediction model on the final decision on mode of delivery has not been revealed yet. One of the questions is if women will change their decisions on mode of delivery at a certain probability on VBAC. Furthermore, a cut-off point between high and low probability of VBAC, and consequently between a high and a low chance of complications, has not yet been defined. Further research should focus on an actual cut-off point, since it could support counseling and risk estimation. 


\section{References}

1. Melman et al. Development and measurement of guidelines-based quality indicators of caesarean section care in The Netherlands: a RAND-modified Delphi procedure and retrospective medical chart review, PlosOne 2016; 11

2. Melman S, Schreurs RHP, Dirksen CD, Kwee A, Nijhuis JG, Smeets NAC, Scheepers HCJ, Hermens RPMG. Identification of barriers and facilitators for optimal cesarean section care: perspective of professionals, BMC Pregnancy Childbirth. 2017 Jul 14;17(1):230.

3. Stacey D, Légaré F, Lewis K, Barry MJ, Bennett CL, Eden KB, Holmes-Rovner M, Llewellyn-Thomas H, Lyddiatt A, Thomson R, Trevena L, Decision aids for people facing health treatment or screening decisions, Cochrane Database Syst Rev. 2017 Apr 12;4(4)

4. Shorten A, Chamberlain M, Shorten B, Kariminia A. Making choices for childbirth: development and testing of a decision-aid for women who have experienced previous caesarean, Patient Educ Couns. 2004 Mar;52(3):307-13.

5. Elwyn G, O'Connor A, Stacey D, Volk R, Edwards A, Coulter A, et al. Developing a quality criteria framework for patient decision aids: online international Delphi consensus process. BMJ 2006;333:417.

6. Dutch Society of Obstetrics and Gynaecology. Guideline: Pregnancy and Childbirth after previous caesarean section, 2010.

7. RCOG. Birth after previous caesarean birth. Green-top Guideline No 45. London RCOG, 2007.

8. ACOG. Vaginal birth after previous cesarean delivery. ACOG, practice bulletin, 2010 (no. 115).

9. Schoorel EN, van Kuijk SM, Melman S, Nijhuis JG, Smits LJ, Aardenburg R, et al. Vaginal birth after a caesarean section: the development of a Western European population-based prediction model for deliveries at term. BJOG, 2014. 121(2): 194-201.

10. McMahon MJ, Luther ER, Bowes WA Jr, Olshan AF, Comparison of a trial of labor with an elective second cesarean section. N Engl J Med, 1996. 335(10): 689-95.

11. Grobman WA, Lai Y, Landon MB, Spong CY, Leveno KJ, Rouse DJ, et al. Can a prediction model for vaginal birth after caesarean also predict the probability of morbidity related to a trial of labour? Am J Obstet Gynecol 2009;200:56.e1-6.

12. Chaillet N, Bujold E, Dubé E, Grobman WA. Validation of a prediction model for predicting the probability of morbidity related to a trial of labour in quebec. J Obstet Gynaecol Can 2012; 34:8205.

13. Metz TD, Stoddard GJ, Henry E, Jackson M, Holmgren C, Esplin S. Simple, validated vaginal birth after caesarean delivery prediction model for use at the time of admission. Obstet Gynecol 2013;122:571-8.

14. Koppes DM, van Hees MSF, Koenders VM, Oudijk MA, Bekker, MN, Franssen MTM, Smits L, Hermens RP, van Kuijk SMJ, Scheepers HCJ, Nationwide implementation of a decision aid on vaginal birth after cesarean: a before and after cohort study, J Perinat Med. 2021 May 31.Online ahead of print

15. Guise JM, Eden K, Emeis C, Denman MA, Marshall N, Fu RR, et al. Vaginal birth after caesarean: new insights. Evid Rep Technol, Assess (Full Rep) 2010;191:1-397 


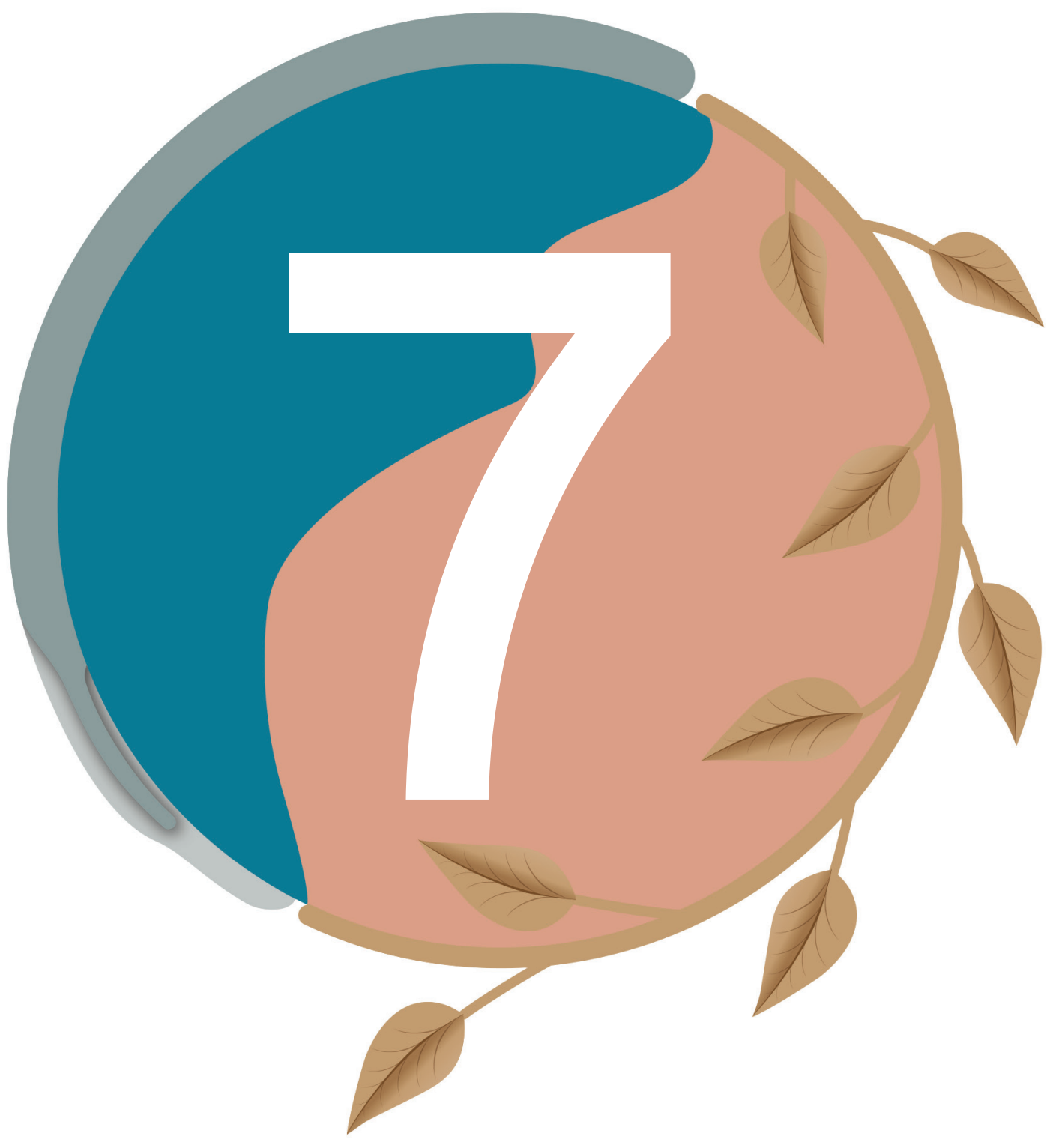


Chapter 7

Impact 


$$
\text { . }
$$




\section{Impact}

\section{Onderzoek}

De keizersnede is een medische ingreep die verricht wordt om complicaties voor moeder en kind te voorkomen of te beperken. Indien een keizersnede verricht wordt zonder goede reden, worden de risico's voor moeder en kind juist groter.

In de afgelopen decennia is het aantal keizersneden wereldwijd fors gestegen. Dit is onwenselijk omdat hiermee het aantal complicaties zal toenemen. Daarnaast stijgen de kosten voor de gezondheidszorg. Met toename van het aantal keizersneden, stijgt ook het aantal vrouwen dat zwanger wordt na een eerdere keizersnede (11\% van alle zwangere vrouwen in 2011 in NL (hoofdstuk 2) en 62 \% van alle uitgevoerde keizersneden [1]). Deze vrouwen hebben meer risico op complicaties in de zwangerschap en bij de bevalling als gevolg van het litteken in de baarmoeder. Het grootste risico is dat tijdens de bevalling het litteken in de baarmoeder openscheurt ("uterusruptuur"), waarbij de kans dat het kind overlijdt ongeveer 10\% is. Echter slechts 15\% van deze vrouwen blijkt de zorg te ontvangen die in de betreffenderichtlijnen geadviseerd wordt. Het doel van dit proefschrift is de huidige zorg rondom vrouwen zwanger na een eerdere keizersnede in kaart te brengen en te verbeteren. Op deze manier willen we verdere toename van het aantal keizersneden en de daarmee gepaard gaande complicaties voorkomen. Daarnaast willen we vrouwen meer te betrekken bij de besluitvorming rondom hun bevalling.

\section{Relevantie}

Wereldwijd zijn er diverse richtlijnen opgesteld die aangeven wanneer een keizersnede moet worden uitgevoerd. Desondanks worden er grote verschillen gezien in het percentage keizersneden dat verricht wordt (16-57\%), waarbij het Nederlandse percentage op 15,7\% ligt [1,2]. Ook in Nederland zijn twee richtlijnen opgesteld door de Nederlandse Vereniging voor Obstetrie en Gynaecologie (NVOG): "Indicatiestelling Sectio Caesarea" en "Zwangerschap en bevalling na voorgaande Sectio Caesarea". Ondanks de duidelijke adviezen worden binnen Nederland grote verschillen gezien in het percentage geplande keizersneden en het percentage vaginale bevallingen bij vrouwen die eerder een keizersnede hebben gehad (hoofdstuk 2). Dit kan komen omdat richtlijnen niet consequent gevolgd worden.

Vrouwen die zwanger zijn na een eerdere keizersnede, moeten in hun nieuwe zwangerschap samen met hun zorgverlener een keuze maken over de manier van bevallen. Als er geen medische bezwaren zijn, kan de zwangere kiezen tussen een geplande keizersnede of proberen vaginaal te bevallen. Dit is een lastige keuze omdat 
het zowel om de gezondheid van de moeder als die van het kind gaat. Het is daarom belangrijk dat vrouwen goed voorgelicht worden over de voor- en nadelen van de opties. Zij geven echter aan dat ze niet voldoende geïnformeerd worden. Het blijkt dat zorgverleners bang zijn voor toename in het aantal keizersneden als ze adequate voorlichting zouden geven [3].

Om patiënten en hulpverleners te ondersteunen in het bespreken van de opties en de gezamenlijke besluitvorming is een keuzehulp ontwikkeld (hoofdstuk 3). Een keuzehulp is een effectief instrument om gezamenlijke besluitvorming te ondersteunen. Het vermindert 'decisional conflict' en verhoogt de kennis van de patiënt $[4,5]$. Patiënten krijgen met de keuzehulp eenduidige informatie volgens de richtlijn over de manier van bevallen. Op deze wijze kan de richtlijnadherentie verhoogd worden. Daarnaast worden patiënten voorgelicht over hun kans op een succesvolle vaginale baring. De persoonlijke kans op een vaginale baring kan een belangrijke rol spelen in de besluitvorming. Het is tevens een voorspeller voor het risico op complicaties voor de moeder. De kans op complicaties is $0,2 \%$ bij vrouwen die vaginaal bevallen, terwijl dit 3,8\% is bij vrouwen die uiteindelijk een ongeplande keizersnede krijgen [6]. We hebben een predictiemodel toegevoegd aan de keuzehulp waarmee de persoonlijke kans op een geslaagd vaginale baring berekend kan worden. Dit model is geschikt voor toepassing in de Nederlandse populatie van vrouwen zwanger na een eerdere keizersnede (hoofdstuk 5). In de huidige literatuur zijn meerdere keuzehulpen en predictiemodellen voor bevallen na eerdere keizersnede beschreven, echter niet eerder werd een predictiemodel toegevoegd aan een keuzehulp.

Ter illustratie is hieronder het predictiemodel toegevoegd waarbij dit is ingevuld voor een vrouw met een normaal BMI van 23, die eerdere een keizersnede heeft gekregen wegens een stuitligging. Ter vergelijking volgt daaronder het predictiemodel dat is ingevuld voor een vrouw met een hoger BMI van 30, die eerder een keizersnede kreeg wegens niet vorderende ontsluiting.

\begin{tabular}{lll}
\hline Variabele & Meetniveau & Waarde \\
\hline BMI $\left(\mathrm{kg} / \mathrm{m}^{\wedge} 2\right)$ voor zwangerschap & continue & 23 \\
Eerdere keizersnede door niet vorderen & $\mathrm{ja}=1$, nee $=0$ & 0 \\
EFW $\geq \mathrm{p90}$ & $\mathrm{ja}=1$, nee $=0$ & 0 \\
Inleiding/priming & $\mathrm{ja}=1, \mathrm{nee}=0$ & 0 \\
Eerdere vaginale partus & $\mathrm{ja}=1$, nee $=0$ & 0 \\
Kaukasisch & $\mathrm{ja}=1$, nee $=0$ & 1 \\
\hline & Kans van slagen & $78,3 \%$ \\
\hline
\end{tabular}




\begin{tabular}{lll}
\hline Variabele & Meetniveau & Waarde \\
\hline BMI (kg/m^2) voor zwangerschap & continue & 30 \\
Eerdere keizersnede door niet vorderen & $j a=1$, nee $=0$ & 1 \\
EFW $\geq$ p90 & $j a=1, n e e=0$ & 0 \\
Inleiding/priming & $j a=1$, nee $=0$ & 0 \\
Eerdere vaginale partus & $j a=1$, nee $=0$ & 0 \\
Kaukasisch & ja $=1$, nee $=0$ & 1 \\
\hline & Kans van slagen & $62,7 \%$ \\
\hline
\end{tabular}

Het gebruik van de keuzehulp met een predictiemodel lijkt niet te leiden tot een afname in het aantal vaginale bevallingen (hoofdstuk 4). Er kan wel een betere risico-selectie gemaakt worden, omdat wordt gezien dat vrouwen die uiteindelijk kiezen voor een poging tot vaginale baring, dit ook vaker lukt. Hierdoor worden minder ongeplande keizersneden verricht. Patiënten worden beter voorgelicht volgens de richtlijnen en voelen zich meer betrokken bij de besluitvorming. Er werden geen duidelijke verschillen in het aantal complicaties gezien. Met de keuzehulp krijgen alle patiënten dezelfde informatie volgens de richtlijn, waardoor de kans op verschillen tussen ziekenhuizen kleiner zal worden.

\section{Doelgroep}

De studies beschreven in dit proefschrift maken onderdeel uit van het Sectio IMPLEmentatie (SIMPLE-) project. Dit is een project waarin gekeken wordt naar de huidige zorg rondom keizersneden, in welke mate de richtlijnen gevolgd worden en hoe de zorg verbeterd kan worden.

In de groep vrouwen zwanger na een eerdere keizersnede bleek maar een klein deel zorg volgens de richtlijn te krijgen. Slechts 15\% werd naar behoren geïnformeerd over de opties van de manier van bevallen.

De doelgroep van dit proefschrift zijn alle vrouwen in Nederland die zwanger zijn na één eerdere keizersnede en:

- $\quad$ zwanger zijn van een eenling

- $\quad$ warbij het kind in hoofdligging ligt

- $\quad$ een voldragen zwangerschap hebben

- $\quad$ warbij geen medische bezwaren bestaan tegen een vaginale bevalling 
Alle studies in dit proefschrift zijn uitgevoerd binnen deze doelgroep. De zorgverleners spelen een cruciale rol in verbetering van deze zorg en het opvolgen van de richtlijnen. Zij counselen de vrouwen over de keuzes en komen tot een (gezamenlijk) besluit. Dit maakt hen tot de tweede doelgroep van deze studie.

\section{Activiteit}

De resultaten van het effect van de keuzehulp zijn gepresenteerd op meerdere nationale en internationale congressen, gepubliceerd in een wetenschappelijk artikel en in het Nederlands tijdschrift voor Obstetrie en Gynaecologie. Het effect van de keuzehulp is nu onderzocht in Nederland en draagt bij aan verbetering van zorg voor vrouwen die zwanger zijn na een eerdere keizersnede.

De volgende stap is de implementatie van de keuzehulp in de standaardzorg voor vrouwen die zwanger zijn na een eerdere keizersnede in Nederland. Er is een implementatie-studie opgezet door Koppes et al [7], waarbij de keuzehulp is toegepast in 30 Nederlandse ziekenhuizen. Het aantal vaginale bevallingen vóor het gebruik van de keuzehulp is vergeleken met het aantal vaginale bevallingen bij het gebruik van de keuzehulp. Hieruit blijkt dat de verschillen tussen de ziekenhuizen in percentage vaginale bevallingen duidelijk is afgenomen. Het gemiddeld aantal keizersneden bleef gelijk en ook het aantal complicaties is niet toegenomen. Om deze reden is het tevens niet te verwachten dat de kosten voor de gezondheidszorg zijn toegenomen.

Gebruik van de keuzehulp leidt dus tot een afname van verschillen tussen ziekenhuizen in de manier van bevallen, een gelijk aantal keizersneden, een gelijk aantal complicaties en betere patiëntbetrokkenheid. De keuzehulp kan nu landelijk geïmplementeerd worden als onderdeel van de standaardzorg.

De keuzehulp wordt nu aangeboden via de patiënten website van de NVOG. Daarnaast kan de keuzehulp nog toegevoegd worden aan de richtlijn "Zwangerschap en bevalling na voorgaande sectio". Op deze manier zal iedere zorgverlener die de richtlijn raadpleegt de keuzehulp zien en kunnen toepassen. De eerder beschreven angst bij zorgverleners voor toename van het aantal keizersneden bij goede voorlichting, kan worden weggenomen.

De keuzehulp is in een aantal talen vertaald, maar nog niet buiten Nederland toegepast. Alvorens de keuzehulp ook in andere landen kan worden toegepast, zal deze daar eerst getoetst moeten worden in een onderzoeksetting. Nederland heeft een hoog percentage vaginale bevallingen na eerdere keizersnede. De keuzehulp met het predictiemodel kan een ander effect hebben in een land met een lager aantal vaginale 
baringen, een andere zorgcultuur of zorgorganisatie. Mogelijk dat de keuzehulp of het predictiemodel aangepast moet worden op de lokale omstandigheden om een vergelijkbaar effect te bereiken. 


\section{Referenties}

1. Euro-Peristat Project. European Perinatal Health Report. Core indicators of the health and care of pregnant women and babies in Europe in 2015. November 2018

2. Perined, Perinatale zorg in Nederland anno 2019: landelijke perinatale cijfers en duiding, Utrecht 2020

3. Melman et al. Identification of barriers and facilitators for optimal cesarean sectio care: perspective of professionals, BMC Pregnancy Childbirth 2017; 17:230

4. Stacey D, Légaré F, Lewis K, Barry MJ, Bennett CL, Eden KB, Holmes-Rovner M, Llewellyn-Thomas H, Lyddiatt A, Thomson R, Trevena L, Decision aids for people facing health treatment or screening decisions, Cochrane Database Syst Rev. 2017 Apr 12;4(4)

5. Shorten A, Chamberlain M, Shorten B, Kariminia A. Making choices for childbirth: development and testing of a decision-aid for women who have experienced previous caesarean, Patient Educ Couns. 2004 Mar;52(3):307-13.

6. McMahon MJ, Luther ER, Bowes WA, Jr., Olshan AF. Comparison of a trial of labor with an elective second cesarean section. N Engl J Med. 1996 Sep 5;335(10):689-95.

7. Koppes DM, van Hees MSF, Koenders VM, Oudijk MA, Bekker, MN, Franssen MTM, Smits L, Hermens RP, van Kuijk SMJ, Scheepers HCJ, Nationwide implementation of a decision aid on vaginal birth after cesarean: a before and after cohort study, J Perinat Med. 2021 May 31.Online ahead of print 



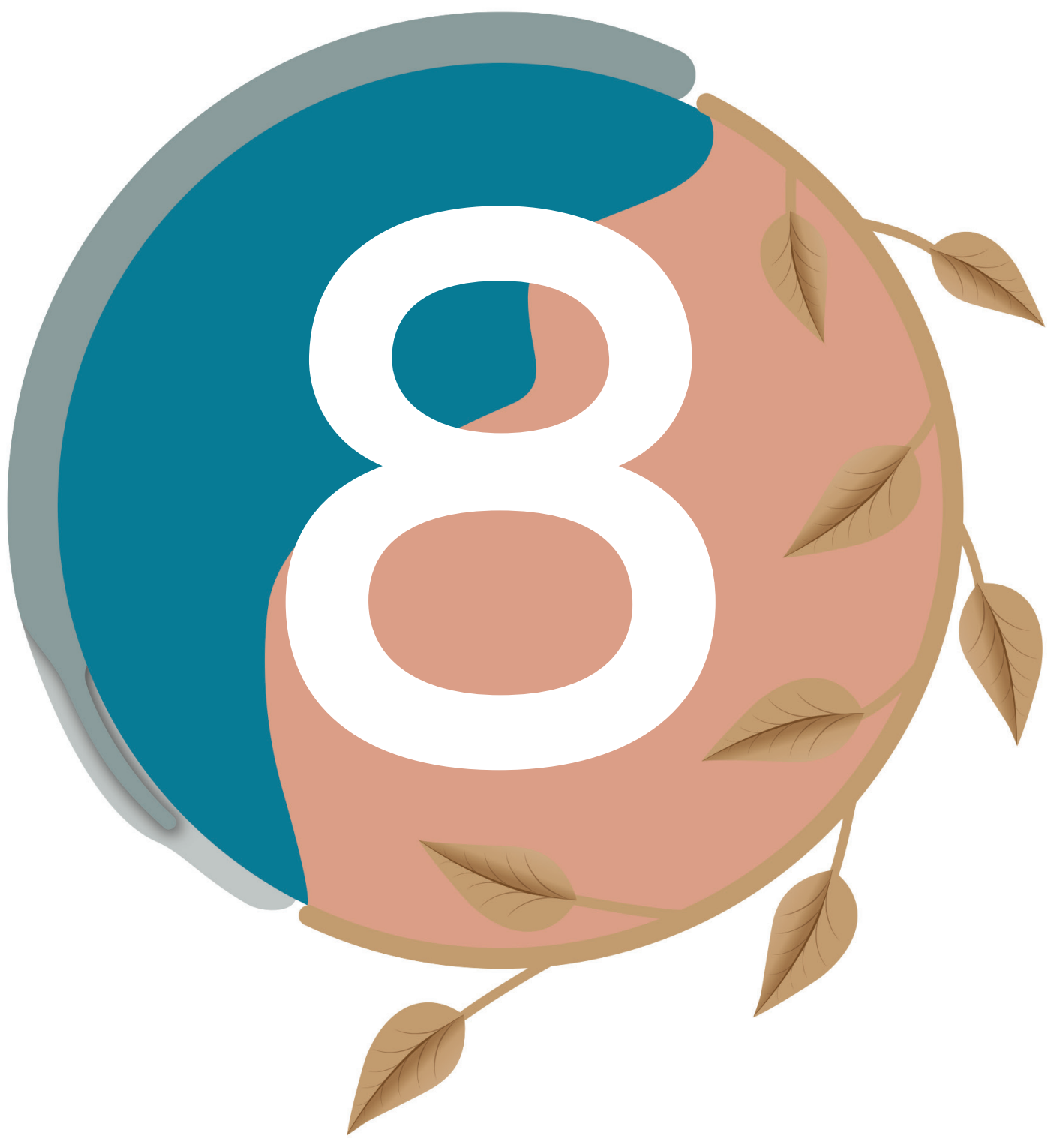


Chapter 8

Nederlandstalige samenvatting 


$$
\text { . }
$$




\section{Nederlandstalige samenvatting}

\section{Achtergrond en doel van het onderzoek}

De keizersnede (sectio Caesarea: SC) heeft als oorspronkelijk doel sterfte van moeder en kind te voorkomen. Wanneer er geen strikte indicatie is voor een SC nemen de risico's voor zowel moeder als kind toe, zonder verbetering van de zwangerschapsuitkomst. De laatste decennia is echter wereldwijd een forse stijging in het aantal SC opgetreden, oplopend tot meer dan 50\% van alle bevallingen in een aantal landen. In Nederland ligt het percentage op $15.7 \%$ in 2019. De stijging kan leiden tot een toename in complicaties voor moeder en kind en hogere kosten voor de gezondheidszorg. Verbetering van de zorg rondom SC is noodzakelijk om een verdere stijging in het aantal SC te voorkomen. In de huidige richtlijnen worden wetenschappelijk onderbouwde adviezen gegeven wanneer een SC uitgevoerd moet worden. Echter de grote variatie in aantal SC wereldwijd suggereert dat de richtlijnen in verschillende mate gevolgd worden.

Met toename van het aantal SC stijgt ook het aantal vrouwen dat zwanger is na een eerdere SC. Ook in deze groep worden verschillen gezien in het volgen van de richtlijnen. Deze vrouwen hebben een grotere kans op complicaties tijdens de zwangerschap en bevalling als gevolg van het litteken in de baarmoeder (uterus), waaronder het optreden van een uterusruptuur. Goede voorlichting over risico's en opties ten aanzien van de manier van bevallen zijn daarom van belang. Indien er geen contra-indicaties zijn, wordt gesteld dat de vrouw een keuze heeft tussen een geplande SC of een poging tot vaginale baring (die kan eindigen in een vaginale baring of een ongeplande SC). Het blijkt echter dat deze vrouwen vaak onvolledig geïnformeerd worden en onvoldoende betrokken worden bij de besluitvorming, vanwege angst bij zorgverleners voor toename van het aantal geplande keizersneden.

Het doel van dit proefschrift is het in kaart brengen van de praktijkvariatie in de manier van bevallen na een eerdere SC en in hoeverre dit wordt beïnvloed door niet patiëntgebonden factoren. Vervolgens is het doel een strategie te ontwikkelen om de richtlijnadherentie en betrokkenheid van de patiënt bij de besluitvorming over de manier van bevallen na eerdere sc te verhogen en deze strategie te toetsen in de praktijk.

\section{Belangrijkste bevindingen}

Hoofdstuk 1 geeft een algemene inleiding over de huidige zorg rondom SC en specifiek de zorg voor vrouwen die zwanger zijn na een eerdere SC. Volgens de huidige richtlijnen hebben vrouwen die zwanger zijn na een eerdere SC een keuze tussen een geplande SC of een poging tot vaginale baring, die kan eindigen in een vaginale baring of een ongeplande SC. Beide opties hebben voordelen en risico's. Een vaginale baring geeft de kleinste kans op 
complicaties, gevolgd door een geplande SC. De grootste kans op complicaties wordt gezien bij een ongeplande SC. Om een gefundeerd besluit te kunnen maken, stellen de richtlijnen dat vrouwen voorgelicht moeten worden over een aantal kernpunten van beide opties: de kans op het slagen van een poging tot vaginale baring, de kans op een uterusruptuur, de verhoogde kans op een uterusruptuur bij inleiding of bijstimulatie, de risico's en voordelen van een geplande SC en de implicaties voor de toekomst van beide opties. Een voorspelling van de persoonlijk te verwachten kans op een vaginale baring kan hierbij heel nuttig zijn.

In hoofdstuk 2 is de variatie in de manier van bevallen na eerdere SC van 763 vrouwen in 17 Nederlandse ziekenhuizen onderzocht. Hieruit bleek dat het percentage vrouwen dat een geplande SC onderging per ziekenhuis varieerde van 6 tot 54\%. Van de vrouwen die een vaginale baring poogden (gemiddeld 67\%), varieerde het aantal geslaagde vaginale baringen van 50 tot $90 \%$. We onderzochten in welke mate deze variatie verklaard kan worden door verschillen in risicofactoren van de patiënten. Door middel van analyses werden de zwaarstwegende risicofactoren vastgesteld, waaronder leeftijd, BMI, ras, eerdere SC wegens niet vorderende baring, eerdere vaginale baring na SC, zwangerschapscomplicaties bij de moeder, en de rijpheid van de portio. Wanneer de percentages geplande SC en vaginale baringen werden gecorrigeerd voor verschillen in deze risicofactoren, bleek 85\% van de variatie hier niet door verklaard te kunnen worden. Een groot deel van de variatie tussen de ziekenhuizen is daarmee niet verklaard. Dit kan erop duiden dat lokaal beleid een belangrijke rol speelt in de besluitvorming over de manier van bevallen na SC. De mate waarin de richtlijnen gevolgd worden kan hierin essentieel zijn.

Hoofdstuk 3 beschrijft de ontwikkeling van een strategie waarmee de richtlijnadherentie verbeterd kan worden en vrouwen meer betrokken worden bij de keuze voor de manier van bevallen na SC. Er is gekozen voor een keuzehulp, die systematisch ontwikkeld werd onder begeleiding van een stuurgroep en een expert-panel. De constructiefase bestond uit het vaststellen van het doel en de doelgroep, de selectie van de inhoud en de vormgeving. In de keuzehulp in boekvorm is objectieve informatie verwerkt en een stappenplan opgenomen om de voorkeur van de patiënt in kaart te brengen en eerdere ervaringen, keuzemogelijkheden en kansen te bespreken. Er is een predictiemodel toegevoegd om de persoonlijke kans op een vaginale baring te berekenen op basis van risicofactoren van de patiënt. Vervolgens beoordeelden 25 vrouwen die zwanger waren na een eerdere SC de keuzehulp in de pilot-test, waarna verbeteringen werden aangebracht. Uit de pilot-test bleek dat de keuzehulp het keuzeproces ondersteunt en verbetert.

In hoofdstuk 4 beschrijven we de toetsing van de keuzehulp in de praktijk. Het doel is het effect van de keuzehulp te onderzoeken op het aantal SC, de richtlijnadherentie en de patiëntbetrokkenheid. In een prospectieve setting werden 6 ziekenhuizen waarin de 
keuzehulp werd toegepast (interventie-groep) vergeleken met 6 ziekenhuizen die standaard zorg gaven (controlegroep). Enkel vrouwen die zwanger waren na één eerdere sectio met nu een kind in hoofdligging à terme en zonder verdere contra-indicaties voor een vaginale baring werden geïncludeerd ( $n=924)$. Er leek geen verschil te zijn in het aantal vaginale baringen tussen de interventie- en de controlegroep (45\%). In de interventie-groep kozen meer vrouwen voor een geplande SC (42\% vs. 31\%). In dezelfde groep zagen we dat vrouwen die kozen voor een poging tot vaginale baring ook vaker vaginaal bevielen (77\% vs. 67\%). In de groep waar de keuzehulp werd toegepast werd vaker gecounseld volgens de richtlijnen (73\% vs. 63\%) en vrouwen voelden zich meer betrokken bij de besluitvorming over de manier van bevallen (98\% vs. 68\%). Het gebruik van de keuzehulp lijkt dus te leiden tot een gelijk aantal vaginale baringen, maar tot een risico-reductie van 40\% op een ongeplande SC, een toename van geplande SC en verhoogde richtlijnadherentie en patiëntbetrokkenheid bij het keuzeproces.

In hoofdstuk 5 presenteren we de externe validatie van het in de keuzehulp toegepaste predictiemodel. Het predictiemodel kan een belangrijke rol spelen in de persoonlijke counseling voor de kans op een vaginale baring. Dit model, ontwikkeld door Schoorel et al., was reeds intern gevalideerd voordat het werd toegepast als onderdeel van de keuzehulp. Om het te kunnen gaan toepassen in de praktijk zal het eerst in de betreffende populatie (Nederland) extern gevalideerd moeten worden. Het predictiemodel bevat 6 voorspellers voor een geslaagde vaginale baring: BMI, eerdere vaginale baring, eerdere SC wegens niet vorderende baring, Kaukasisch ras, een geschat gewicht van het kind boven de 90ste percentiel en een inleiding van de baring in de huidige zwangerschap. In deze studie werden 586 vrouwen geïncludeerd die een poging tot vaginale baring wensten.

Het aantal geslaagde vaginale baringen werd vergeleken met het voorspelde aantal vaginale baringen door het predictiemodel. Hieruit bleek dat het predictiemodel een goed onderscheidend en voorspellend vermogen heeft. Bij een lage kans op succesvolle vaginale baring is er enige overschatting door het model, waar er tevens onderschatting is wanneer er een hoge kans is op een vaginale baring. Het predictiemodel presteert adequaat in een Nederlandse populatie en kan toegepast gaan worden in de dagelijkse praktijk als onderdeel van de counseling.

Hoofdstuk 6 bevat een algemene discussie over de resultaten van dit proefschrift. Daarnaast wordt er verder ingegaan op de implicaties voor de dagelijkse praktijk en worden suggesties gedaan voor toekomstig onderzoek. 


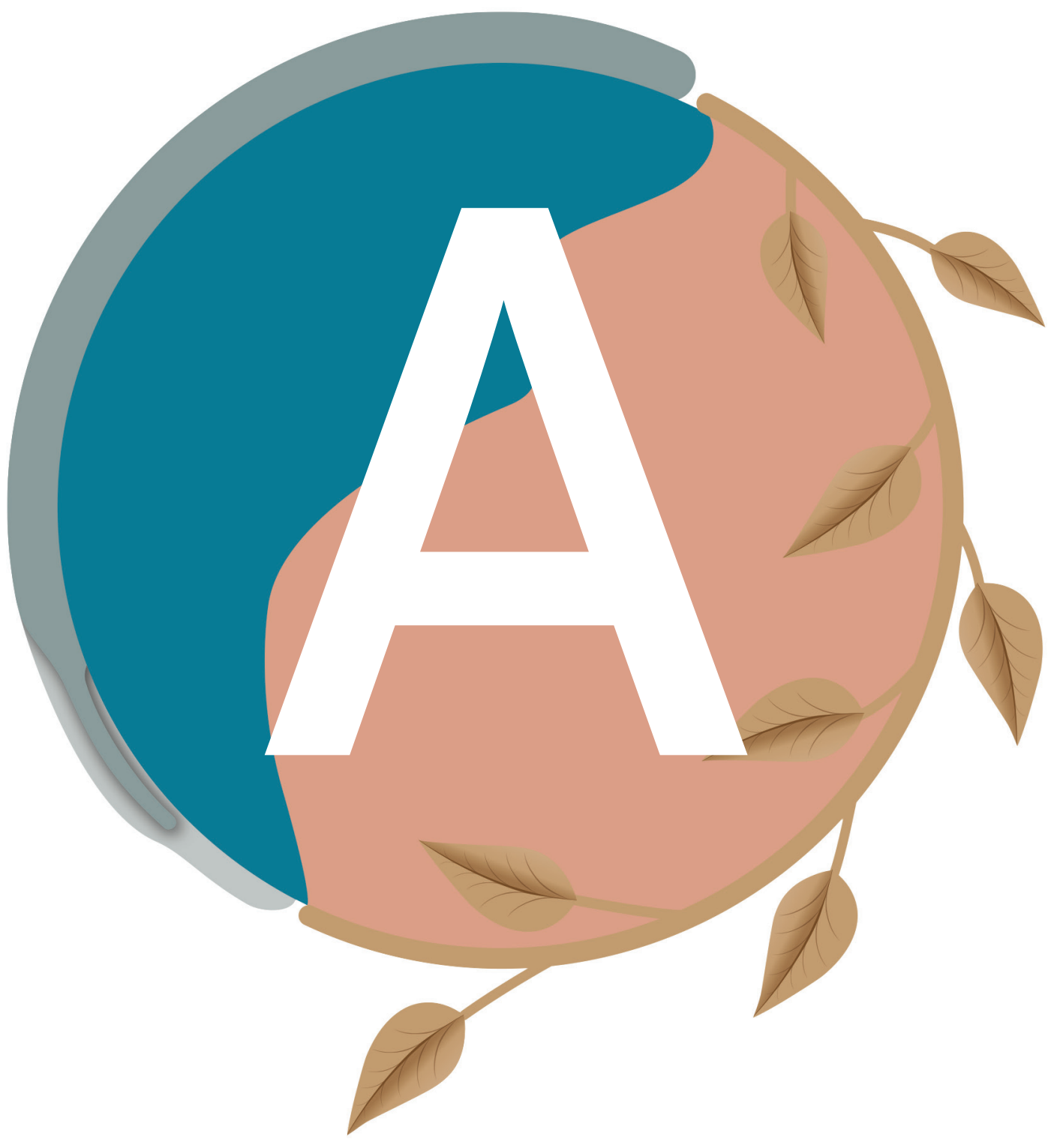




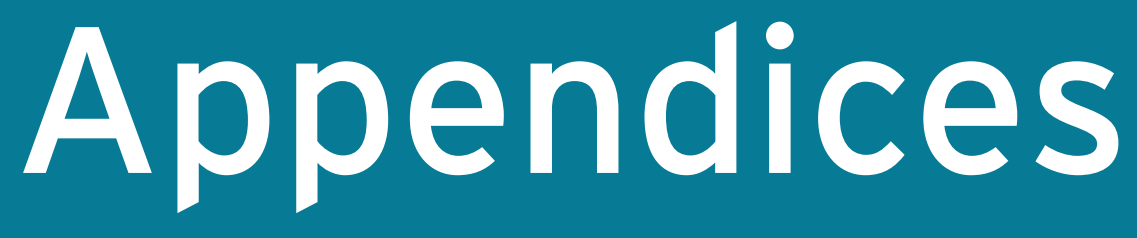

Dankwoord

Curriculum Vitae

List of publications 


$$
\text { . }
$$




\section{Dankwoord}

Het schrijven van een proefschrift is te vergelijken met een lange reis. Eerst tref je goede voorbereidingen en laat je je voorlichten door ervaren reizigers. Dan maak je een paklijst, verzamelt alles en je vertrekt. Onderweg kom je obstakels tegen waar je geholpen wordt door andere reizigers, leer je veel van de lokale bewoners en maak je één voor één gebruik van alles wat je in je rugzak hebt gedaan. Meerdere personen helpen je met de route en geven je ook weer nieuwe spullen mee voor in je rugzak. Een gids helpt je met beklimmen van een berg, waar je uiteindelijk beloond wordt met een prachtig uitzicht, maar je daalt ook af tot je met knieën in het water staat. En uiteindelijk kom je voldaan thuis met een tas vol ervaring. Deze reis kun je, net als het promotie-traject, nooit in je eentje maken. Daarom wil ik iedereen die mij begeleid en ondersteund heeft bij het maken van dit proefschrift bedanken.

Allereerst wil ik alle zwangeren die hebben deelgenomen aan het onderzoek hartelijk bedanken. Dank aan de artsen en gynaecologen van de deelnemende centra voor het voorlichten en includeren van de patiënten en de research medewerkers voor het verzamelen van alle data.

Graag wil ik mijn promotor en co-promotoren bedanken voor de begeleiding bij het maken van dit proefschrift.

Prof. J.G. Nijhuis, hartelijk dank voor uw begeleiding tijdens mijn promotie-traject. Uw scherpe blik en daaropvolgend de nuttige feedback op de manuscripten zorgden voor de juiste verdieping en de puntjes op de i. Lastige situaties kon u voor mij vaak goed verhelderen, zowel tijdens het promotie-traject als in de kliniek. Uw kijk op het al dan niet verrichten van een sectio (ook op verzoek), zette aan het denken, vooral als er nog een mooie casus als voorbeeld bij werd gegeven. Handvaten en bemoedigende woorden als het onderzoek wat stroever liep, zorgde ervoor dat ik weer vooruit kon. I $k$ vind het een eer een van uw laatste promovenda te zijn en wens u een ontspannen pensioen toe in goede gezondheid.

Dr. H.C.J. Scheepers, beste Liesbeth, voor mij de stuwende kracht achter het promotietraject en de SIMPLE-studie. Je enthousiasme voor wetenschappelijk onderzoek werkt aanstekelijk en de ideeën die je hebt zijn eindeloos. Dank je wel voor het vertrouwen dat je me hebt gegeven om te mogen starten met dit promotie-traject. Daarnaast wil ik je bedanken voor je intensieve begeleiding, betrokkenheid, je optimistische houding (als ik hem even niet meer had) en de ruimte die je me gaf om dit proefschrift te kunnen voltooien. Ik heb veel van je geleerd. Zonder jou was het niet gelukt! 
Dr. R.P.M.G. Hermens, beste Rosella, hoewel de afstand naar Nijmegen groter is dan naar Maastricht en we elkaar minder makkelijk konden ontmoeten, nam je telefonisch of via de mail uitgebreid de tijd om te discussiëren over de opzet van het onderzoek of de manuscripten. Je kritische en doortastende blik zorgden voor de juiste diepgang en helderheid, belangrijk voor mijn basis als onderzoeker. Dank je wel voor je rust, uitgebreide uitleg en begeleiding.

Liesbeth en Rosella, jullie mogen trots zijn op de SIMPLE-onderzoekslijn. Heel mooi hoe de keuzehulp nu landelijk in de dagelijks praktijk gebruikt wordt en voor alle betrokken zwangeren bijdraagt aan een goed onderbouwde keuze.

De leden van de beoordelingscommissie, Prof. dr. P.W. Teunissen, Prof. dr. M.L. Smidt, Dr. L. Wynants, Dr. A.C.M.J. Merkx en Dr. J. Braspenning, wil ik bedanken voor de beoordeling van dit proefschrift.

Graag wil ik de leden van de SIMPLE projectgroep bedanken: dr. Luc Smits, prof. dr. Carmen Dirksen, prof. dr. Ben-Willem Mol, dr. Robert Aardenburg, dr. Friso Delemarre, drs. Ivo van Dooren, dr. Simone Kuppens, dr. Anneke Kwee en dr. Josje Langenveld voor jullie begeleiding en inzet bij de opzet en uitvoering van de SIMPLEstudie en jullie feedback op de manuscripten.

Dr. Sander van Kuijk, beste Sander, dank je wel voor alles wat ik van je heb mogen leren. Het enthousiasme en plezier waarmee je me wegwijs maakte in de statistiek en methodologie heb ik erg gewaardeerd. Hoe ingewikkeld ook in mijn ogen, je wist altijd het antwoord op mijn vraagstukken en kon dit ook nog zo uitleggen dat het heel simpel leek. Je hebt daarmee een belangrijke bijdrage geleverd aan dit proefschrift. Dank je wel voor je uitleg, je geduld en de fijne samenwerking.

Ellen Schoorel en Sonja Melman, mijn SIMPLE studiegenoten, dank jullie wel voor de fijne samenwerking en de spar-momentjes. Sonja, je hebt de basis gelegd voor de SIMPLE-studie, waarop wij verder konden. Ellen, in het begin hebben we intensief samengewerkt en heb ik veel van je geleerd over de opzet, logistiek en alles wat komt kijken bij de uitvoering van het onderzoek, voor mij cruciaal voor een goede start. De samenwerking vond ik erg fijn en je hebt veel van je wetenschappelijke ervaring met mij als "groentje" gedeeld. Toen je zelf eenmaal gepromoveerd was, stond je nog altijd klaar om vragen te beantwoorden of bestanden op te sporen. Dank je wel dat je me hebt klaargestoomd voor dit promotieonderzoek en dat je altijd bereid was te helpen, dat heb ik erg gewaardeerd. 
Ik wil alle studenten die geholpen hebben bij de opzet en uitvoering van het onderzoek bedanken: Dorien Hünen, Anouk van den Bosch, Nina Achten, Laura Baeten, Valerie Stegehuis en Nina Laeven. Bedankt voor jullie inzet en de fijne samenwerking!

Nienke Zwakman, we deelden een kamer tijdens mijn schrijfstage. Je enthousiasme en positieve houding zorgde voor een fijne en effectieve werksfeer, dank je wel! Na een kwartiertje dansen bij de radio konden we er weer tegenaan. Je mag trots zijn op wat je al bereikt hebt binnen het doen van onderzoek.

Beste leden van de maatschap gynaecologie van het Atrium/Zuyderland en de vakgroep gynaecologie van het $\mathbf{M U M C}$, dank voor het enthousiasme en het vertrouwen waarmee jullie mij hebben opgeleid tot gynaecoloog en de interesse en ruimte die ik kreeg voor mijn promotieonderzoek.

Oud-collega $\mathbf{A}(\mathbf{N})$ IOS van het Atrium/Zuyderland en MUMC, bedankt voor de altijd fijne samenwerking. Samen hard werken, ervaringen delen, Iol maken en er voor elkaar zijn heb ik erg gewaardeerd. Ook het sparren/spuien als we in hetzelfde "promotie-schuitje" zaten, was vaak verhelderend. Bedankt voor deze fijne tijd en veel succes met de wegen die jullie nu bewandelen.

Daisy en Ewka, bedankt voor de gezelligheid en het luisterende oor. We hebben tijdens onze opleiding veel gedeeld en proberen nu nog regelmatig samen een congres te plannen zodat we weer even kunnen bijpraten.

Kelly, lieve Kel, mijn opleidingsmaatje vanaf dag 1 waar ik erg dankbaar voor ben, van onze eerste sollicitatie als ANIOS tot het afzwaaien als jonge klare. We werden door anderen "Emelly" of de "Twin towers" genoemd. Vaak aan het einde van de dag nog even napraten op de assistentenkamer over wat we allemaal meegemaakt of geleerd hadden. Menige cursus en congres hebben we samen bezocht (behalve dan die gemiste colposcopie-cursus). Samen zijn we "groot" geworden. Ik ben heel trots op je, hoe je in het leven staat met je lieve gezin. Super dat je die mooie baan in Nijmegen te pakken hebt, veel geluk en succes!

De vakgroep gynaecologie van het Zuyderland, beste maten; deze afdeling heeft altijd als mijn thuis gevoeld. Vanaf semi-arts tot arts-assistent tot nu uiteindelijk als vakgroeplid heb ik mogen zien dat er enorme sprongen zijn gemaakt de afgelopen jaren op gebied van opleiding, innovatie en patiëntenzorg. Jullie mogen hier heel trots op zijn. Ik ben dankbaar dat ik onderdeel mag zijn van deze fijne club. Dank 
jullie wel voor het vertrouwen, de interesse in mij als persoon en de steun en ruimte die jullie me hebben gegeven om dit proefschrift te kunnen afronden. Ik kijk uit naar een vruchtbare samenwerking in de toekomst.

Arts-assistenten van het Zuyderland; dank je wel voor jullie enthousiasme, leergierigheid en positieve bijdrage aan de werksfeer en patiëntenzorg.

Verloskundigen, PA'ers, verpleegkundigen, verpleegkundig specialisten, polidames, echoscopisten en POK en OK-personeel van het Zuyderland, dank voor jullie inzet, interesse en de fijne samenwerking.

Evelien Jagtman, beste Evelien, dank je wel voor het maken van het mooie ontwerp van mijn proefschrift, ik ben er erg blij mee! Bijzonder hoe je dit na al mijn input op papier kunt zetten. Mariska Offerman, bedankt voor het opmaken van mijn proefschrift.

Dan wil ik graag mijn vrienden en vriendinnen bedanken.

Vrienden van de "uni-groep"; helaas zien we elkaar niet meer zo vaak nu we allemaal zijn uitgevlogen, maar de interesse naar elkaar blijft en als we elkaar zien is het als vanouds. Dank jullie wel daarvoor!

Volleybalmutsen, wat is het heerlijk om het weekend te beginnen met een potje volleybal met je vriendinnen. Stoom afblazen na een week werken, fanatiek zijn we nog allemaal. Maar ook even bijkletsen daarna in de kantine, vaak met veel lol, soms serieus. Dank jullie wel voor alle gezelligheid en steun. Ik hoop dat we nog vele jaren als team mogen doorgaan, zou het niet willen missen.

Lieve Ellen, volleybalvriendin vanaf het eerste moment, je nuchtere kijk op dingen is verfrissend en je kan me echt de slappe lach bezorgen. Je vraagt altijd belangstellend naar de dingen die ik doe en staat voor me klaar als het nodig is. Ik ben dankbaar voor onze vriendschap. Laten we de uitjes met de meisjes erin houden, want dat bevalt erg goed!

Lieve Piet en Janneke, dank jullie wel voor jullie vriendschap. Ook al wonen we niet (meer) bij elkaar om de hoek, we weten dat jullie er voor ons zijn. Avondjes zijn dan ook weekendjes met logeerpartijen geworden, maar dat is wel zo fijn, want het wordt met jullie altijd gezellig laat met eindeloos veel lekkers op tafel.

Lieve Daan en Veer, wat vind ik het een eer dat jullie vandaag naast mij staan als paranimfen. 
Onze vriendschap stamt uit de middelbare schooltijd en wat hebben we veel beleefd samen sindsdien. Waar we begonnen met schoolreizen naar Rome en Praag, gaan we nu een weekend kamperen met de kids. Het volwassen leven is inmiddels een feit, maar zowel bij een lach als een traan staan we naast elkaar en dat is een heel fijn gevoel. Bij jullie kan ik mezelf zijn en kan ik m'n ei kwijt, maar ook heel hard lachen. Heel erg bedankt voor jullie vriendschap en dat jullie mijn paranimfen willen zijn.

Lieve schoonfamilie, bedankt voor jullie interesse in mijn werk en mij als persoon. Het is fijn dat we ons altijd welkom voelen bij jullie en dat even binnenlopen altijd kan. Ook een oppasdagje is nooit te veel. Fijn om te zien dat het jullie allemaal goed gaat na roerige tijden.

Lieve Nadine en Babette, mijn zussies, wat is het fijn dat we zo'n goede band hebben. Als we elkaar zien is het altijd erg gezellig (anderen zeggen dat het klinkt als een kippenhok). Ik bewonder wat jullie allemaal doen en ben erg trots op jullie! Dank jullie en Erwin en Dean voor jullie betrokkenheid, interesse en steun, ook als door mijn werkzaamheden afspraken aangepast moesten worden. Ik bof maar met jullie. Het wordt weer hoog tijd voor een zussendag! Ondertussen worden we een steeds grotere happy family, wat is het leuk dit te delen!

Lieve Pap en Mam, bedankt dat jullie er altijd voor mij geweest zijn. Vanuit een veilig en warm nest hebben jullie me gestimuleerd en gesteund om voor mijn doelen en dromen te gaan. Jullie zijn altijd belangrijk geweest bij grote keuzes die ik maakte. Soms opperde jullie uit bezorgdheid wel voorzichtig of het niet te veel was, maar jullie steunden mij altijd en leerden mij zelf te beslissen. Als ik voor mijn proefschrift meters moesten maken sprongen jullie bij met oppassen of koken en als ik even mijn verhaal kwijt moest hadden jullie een luisterend oor. Ik waardeer het enorm. Bedankt voor alles!

Lieve Mar, mijn lief, wat ben ik blij met jou aan mijn zij. Zonder jou was dit proefschrift er niet gekomen. Je zorgde voor rust en ruimte thuis zodat ik kon werken, ook al moest je daarvoor soms jezelf wegcijferen. Als het even niet lekker liep met het onderzoek, wist je me toch te motiveren zonder te pushen. Ik bewonder je discipline en motivatie om je doelen na te streven, die zijn ijzersterk. Je zorgde er ook voor dat ik op mezelf bleef letten en tijd nam om af te schakelen door samen leuke dingen te doen. Het waren met periodes drukke tijden waarin je erg flexibel moest zijn. Dank je wel voor al je hulp, steun, liefde en alle goede zorgen voor ons gezin. Ik kijk uit naar al het moois wat ons samen nog te wachten staat. Ik ben enorm trots op je en hou van je!

Lieve Puk, jij tovert een lach op mijn gezicht zodra ik thuiskom en zorgt dat ik dan ook even alles kan vergeten. Ik kijk er naar uit dat je straks een grote zus wordt. 


$$
\text { . }
$$




\section{Curriculum Vitae}

Emy Vankan werd op 9 juni 1984 geboren in Brunssum. In juni 2002 behaalde zij haar VWO diploma aan het Rombouts College te Brunssum. Na uitgeloot te zijn voor de studie Geneeskunde begon ze met de studie Gezondheidswetenschappen in Maastricht. Na enkele weken werd zij echter alsnog ingeloot, waardoor ze kon starten met de studie Geneeskunde aan de Universiteit van Maastricht in september 2002. Ze voltooide haar opleiding in 2008, waarna ze een jaar op wereldreis ging. In 2009 begon ze als arts-assistent niet in opleiding tot medisch specialist gynaecologie en verloskunde in het Elisabeth Ziekenhuis te Tilburg en vervolgens in het Atrium Medisch Centrum te Heerlen (2010-2011). Vanaf 1 januari 2012 startte ze met de opleiding tot gynaecoloog, waarbij zij haar opleiding volgde in het Atrium Medisch Centrum/Zuyderland Medisch Centrum (opleider dr. P.E.A.M. Mercelina, plaatsvervangend opleider F.J.M.E. Roumen en later opleider dr. M.M.L.H. Wassen en plaatsvervangend opleider N.A.C. Smeets) en in het MUMC+ (opleider Prof. R.F.P.M. Kruitwagen, plaatsvervangend opleider dr. G.A.J. Dunselman). Tijdens haar opleiding start ze met de SIMPLE II studie zoals beschreven in dit proefschrift. Ze trouwt op 11 juli 2014 met Marco van Bun en ze krijgen samen een dochter, Puk op 2 december 2017. De opleiding tot gynaecoloog rondde ze af op 30 september 2018. Vanaf 1 oktober 2018 is ze werkzaam als gynaecoloog in het Zuyderland Medisch Centrum. 


$$
\text { . }
$$




\section{Publication list}

Schoorel EN, Vankan E, Scheepers HC, Augustijn BC, Dirksen CD, de Koning M, van Kuijk SM, Kwee A, Melman S, Nijhuis JG, Aardenburg R, de Boer K, Hasaart TH, Mol BW, Nieuwenhuijze M, van Pampus MG, van Roosmalen J, Roumen FJ, de Vries R, Wouters MG, van der Weijden T, Hermens RP, Involving women in personalised decision-making on mode of delivery after caesarean section: the development and pilot testing of a patient decision aid, BJOG. 2014 Jan;121(2):202-9.

Vankan E, Schoorel EN, van Kuijk SM, Mol BJ, Nijhuis JG, Aardenburg R, Alink M, de Boer K, Delemarre FM, Dirksen CD, van Dooren IM, Franssen MT, Kaplan M, Kleiverda G, Kuppens SM, Kwee A, Langenveld J, Lim FT, Melman S, Sikkema MJ, Smits LJ, Visser H, Woiski M, Scheepers HC, Hermens RP, Practice variation of vaginal birth after cesarean and the influence of risk factors at patient level: a retrospective cohort study, Acta Obstet Gynecol Scand. 2017 Feb;96(2):158-165.

Vankan E, Schoorel E, van Kuijk S, Nijhuis J, Hermens R, Scheepers H, SIMPLE study group, The effect of the use of a decision aid with individual risk estimation on the mode of delivery after caesarean section: A prospective cohort study, PLoS One. 2019 Sep 26;14(9):e0222499. doi: 10.1371/journal.pone.0222499. eCollection 2019

Vankan E, van Kuijk SMJ, Nijhuis JG, Aardenburg R, Delemarre FMC, Dirksen CD, van Dooren IM, Kuppens SMI, Kwee A, Langenveld J, Schoorel EN, Smits LJ, Hermens RP, Scheepers HC, External validation of a prediction model on vaginal birth after caesarean in a The Netherlands: a prospective cohort study,

J Perinat Med. 2020 Nov 6:49(3):357-363. doi: 10.1515/.jpm-2020-0308. Print 2021 Mar 26. PMID: 33155996 


\section{Presentations}

Vankan E, Schoorel EN, van Kuijk SMJ, Nijhuis JG, Aardenburg R, Delemarre FMC, Dirksen CD, van Dooren IM, Kuppens SMI, Kwee A, Langenveld J, Smits LJ, Hermens RP, Scheepers HC,

Patient decision aid with individual risk estimation: effective tool in choosing the mode of delivery after cesarean delivery, European Congress Intrapartum Care, 2015, Porto, Portugal (oral presentation)

Vankan E, Schoorel EN, van Kuijk SMJ, Nijhuis JG, Aardenburg R, Delemarre FMC, Dirksen CD, van Dooren IM, Kuppens SMI, Kwee A, Langenveld J, Smits LJ, Hermens RP, Scheepers HC,

Keuzehulp met individuele risicoberekening: effectief hulpmiddel bij het kiezen voor de modus partus na eerdere sectio caesarea, Gynaecongres, 2015, Amersfoort (oral presentation)

Vankan E, Schoorel EN, van Kuijk SMJ, Nijhuis JG, Aardenburg R, Delemarre FMC, Dirksen CD, van Dooren IM, Kuppens SMI, Kwee A, Langenveld J, Smits LJ, Hermens RP, Scheepers HC,

Patient decision aid with individual risk estimation: an effective tool in choosing the mode of delivery after caesarean section, European Congress Perinatal Medicine, 2016, Maastricht (oral presentation)

E. Vankan, E.N.C. Schoorel, S.M.J. van Kuijk, R. Aardenburg, F.M.C. Delemarre, C.D. Dirksen, I.M. van Dooren, S.M.I. Kuppens, A. Kwee, J. Langenveld, B.W.J. Mol, J.G. Nijhuis, R.P.M.G. Hermens, H.C.J. Scheepers, Patient decision aid with individual risk estimation: a effective tool in choosing the mode of delivery after cesarean delivery, SMFM, 2015, San Diego, United States of America (poster presentation)

E.Vankan, N.A.C. Smeets, Urinothorax after hysterectomy; a rare case, ESGE, 2011, London, United Kingdom (poster presentation) 